\title{
Fish and aquatic habitat conservation in South America: a continental overview with emphasis on neotropical systems
}

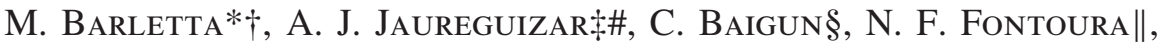 \\ A. A. AgostinhoII, V. M. F. Almeida-Val**, A. L. Val**,
}

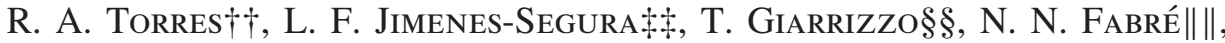
V. S. Batista \|\| , C. LassođII, D. C. TaphornIII, M. F. Costa*,

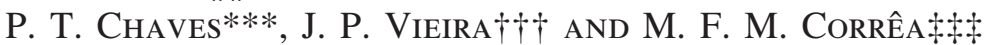

*Laboratório de Ecologia e Gerenciamento de Ecossistemas Costeiros e Estuarinos, Departamento de Oceanografia, Universidade Federal de Pernambuco, Cidade Universitária, 50740-550, Recife, Pernambuco, Brazil, $\ddagger$ Instituto Nacional de Investigación y Desarrollo Pesquero, Paseo Victoria Ocampo N 1, P. O. Box 175, Mar Del Plata (7600), Argentina, \#Comisión de Investigaciones Científicas (CIC), Calle 526 entre 10 y 11, La Plata, Argentina §Instituto Tecnologico de Chascomus, Camino de Circunvalación Laguna km 6, 7130

Chascomus, Argentina, \|Departamento de Biodiversidade e Ecologia, Faculdade de Biociências - PUCRS. Av. Ipiranga 6681, Prédio 12-C, Sala 173, 90619-900, Porto Alegre, Rio Grande do Sul, Brazil, IINupelia, Universidade Estadual de Maringá, Av. Colombo 5790, 87020-900, Maringá, Paraná, Brazil, **Instituto Nacional de Pesquisas da Amazônia (INPA), Manaus, Amazonas, Brazil, ††Laboratório de Genética Evolutiva e Animal, Departamento de Zoologia, Universidade Federal de Pernambuco, Cidade Universitária, Recife, Pernambuco, Brazil, \$\$Instituto de Biología, Universidad de Antioquia, Medellín, Colombia, §§Laboratório de Biologia Pesqueira, Manejo dos Recursos Aquáticos da Universidade Federal do Pará, Av. Perimetral 2651, Terra Firme 66040-170, Belém, Pará, Brazil, |||Universidade Federal de Alagoas - ICBS, Maceió, Alagoas, Brazil, IIIInstituto de Investigación de los Recursos Biológicos Alexander von Humbolt, Calle 28a $N^{\circ}$ 15-09, Bogotá, Colombia,

***Departamento de Zoologia, Universidade Federal do Paraná, Centro Politécnico, C.

P. 19020, CEP 81531-980, Curitiba, Paraná, Brazil, ††Laboratório de Ictiologia, Departamento de Oceanografia, Fundação Universidade Federal de Rio Grande, C. P. 474, CEP 96201-900, Rio Grande, RS, Brazil and $\$ \$$ Centro de Estudos do Mar, Universidade Federal do Paraná, Av. Beira Mar s/n. Pontal do Paraná, Paraná, Brazil

\begin{abstract}
Fish conservation in South America is a pressing issue. The biodiversity of fishes, just as with all other groups of plants and animals, is far from fully known. Continuing habitat loss may result in biodiversity losses before full species diversity is known. In this review, the main river basins of South America (Magdalena, Orinoco, Amazon and Paraná-La Plata system), together with key aquatic habitats (mangrove-fringed estuaries of the tropical humid, tropical semi-arid and subtropical regions) are analysed in terms of their characteristics and main concerns. Habitat loss was the main concern identified for all South American ecosystems. It may be caused by damming of rivers, deforestation, water pollution, mining, poor agricultural practice or inadequate management practice. Habitat loss has a direct consequence, which is a decrease in the availability of living resources, a serious social and economic issue, especially for South American nations which are all developing countries. The introduction of exotic species and overfishing were also identified as widespread across the continent and its main freshwater, coastal and marine ecosystems. Finally,
\end{abstract}

$\dagger$ Author to whom correspondence should be addressed. Tel.-fax: +55 8121268225; email: mario.barletta@ pq.cnpq.br 
suggestions are made to find ways to overcome these problems. The main suggestion is a change of paradigm and a new design for conservation actions, starting with integrated research and aiming at the co-ordinated and harmonized management of the main transboundary waters of the continent. The actions would be focused on habitat conservation and social rescue of the less well-off populations of indigenous and non-indigenous peoples. Energy and freshwater demands will also have to be rescaled in order to control habitat loss.

(c) 2010 The Authors

Journal compilation (c) 2010 The Fisheries Society of the British Isles

Key words: ecosystem conservation; estuary; Magdalena, Orinoco, Amazon, Paraná, Paraguay, Uruguay, La Plata River basins; mangrove forest; neotropical fishes; Patos Lagoon.

\section{INTRODUCTION}

Despite the uneven information in terms of quality, quantity and antiquity, South American biomes, and especially aquatic environments, are evidently suffering from very similar effects. Economic and social pressure on developing countries has only increased with the new globalized economy. In the last 500 years, South America has been exploited by different groups of Western nations. The exploitation cycles have all followed similar patterns, and currently the main environmental challenges faced by every South American nation are clean power generation and sufficient food production for their whole populations. The challenge is to achieve these goals in a sustainable way, with minimum environmental damage. How will fish species, populations and communities suffer on the continent with the most fresh water on Earth? What does the future hold for aquatic environments and fish conservation in South America, and what will be the role of science?

What is known is that information, most not readily available, is concentrated in government institutions distributed strategically on the continent according to official interests. Most of the information generated about fishes in South America is of a taxonomic and systematic nature. This is already a good starting point, but the needs have grown faster than scientific institutions and human capabilities. The most needed information is that of an ecological, systemic and integrated nature. Lack of the appropriate information about ecology, biology and taxonomy (especially in the remote Amazon basins) for each biome and basin within the continent was one of the common diagnoses of all authors participating in this review. Without this information, there is no possibility of integrated (river-estuary-coastal area) management for the continent. Basins in South America are large and drain enormous volumes of water. Most of these biomes and basins are transboundary ecological units. Due to the absence, or ineffectiveness, of international environmental policies among countries, most of these biomes are not under the same management programmes or environmental legislation. When integration is achieved, it is usually due to prevailing economic and development interests. Mitigating actions, when put in place, are often carried out without sound scientific data or analysis, surprisingly in most cases due to lack of both aquatic abiotic and biotic monitoring.

In addition to the political and scientific dimensions, there are the social issues linked to good or bad catchment and aquatic resources management and conservation practice. Poverty and deficient basic education are well-known sources of environmental degradation, and so is hunger. South American countries share a history of social inequality that has cost the environment dearly. Both freshwater and 
marine fisheries in South America are showing clear signs of decline and, in some isolated cases, total collapse. The causes are habitat loss (damming of rivers, deforestation and pollution), overfishing, introduction of exotic species and poor fisheries management (Agostinho et al., 2008; Alves \& Fontoura, 2009; Barletta \& Costa, 2009; Viana et al., 2010; M. Barletta, M.F. Costa, A.C.R. Couto, M.F.M. Corrêa \& U. Saint-Paul, unpubl.data).

Understanding the effects of short and large-scale patterns in abiotic conditions is also necessary for a more complete understanding of ecosystem ecology and therefore effective management. Such understanding includes material and energy fluxes, trophic transfers and connectivity, and fisheries dynamics. The linkage between ecosystem and management practice is provided by solid ecological knowledge and understanding of the ecosystem dynamics in which it operates (Barletta et al., 2008).

The present work provides an overview of the environmental influences [natural (warm waters depleted of dissolved oxygen and the El Niño events) and anthropogenic effects (damming of rivers, sewage pollution, mining and overfishing) on fish community distribution dynamics, and habitat connectivity] and suggests ecological studies needed to develop future river basin-estuary-coastal area management plans for effective ecosystem protection and fish conservation on a continental scale.

This is the first initiative to gather not only information but also opinions from well-established scientists across the continent dealing with fish sciences in general and conservation in particular. The intention is to produce a review of the common problems that affect fishes and fish conservation that affect the continent and thereby help decision-makers to achieve the common goals of guaranteeing an environment, water, power and food supply of sufficient quality for the whole of South America.

The South American continent spans over $85^{\circ}$ of latitude $\left(30^{\circ} \mathrm{N}\right.$ to $\left.55^{\circ} \mathrm{S}\right)$, and anthropogenic interventions are as diverse as climate, geology and ecosystem use and conservation. Estuaries vary tremendously from both the natural and the human use point of view. The levels of social and economic development of South American nations and their different regions are a key determinant in estuarine environmental quality, services available and conservation options. The continent presents on the one hand, pristine areas, such as those of the Colombian Pacific Ocean; but on the other hand, estuaries and coastal ecosystems that have been severely modified during the 500 years of European colonization, as demonstrated by Todos os Santos Bay and the eastern Brazilian coast. The development process occurred mainly through exchange of people and goods with European centres as well as with Africa. For such exchange, an intense seafaring trade was established. Ports were built on almost every large harbour of the Atlantic and Pacific Ocean coasts. These ports are now maintained by frequent dredging operations (M. Barletta, M.F. Costa, A.C.R. Couto, M.F.M. Corrêa \& U. Saint-Paul, unpubl.data), necessary because of poor conservation of river basins (deforestation and riverbed aggradation) and increases in the sizes of ships resulting from accelerated economic development.

Global water environment assessments (UNEP, 2004a, b) define seven broad provinces for the South American continent, each encompassing different settings of coastal and marine environmental conditions, including ecological, environmental and socio-economic situations (Fig. 1). Therefore, anthropogenic effects on the aquatic environment and its consequence on aquatic animals and fisheries are also very diverse. Moreover, according to Humphries \& Winemiller (2009), the critical situation for South American aquatic ecosystems are not exceptional relative 


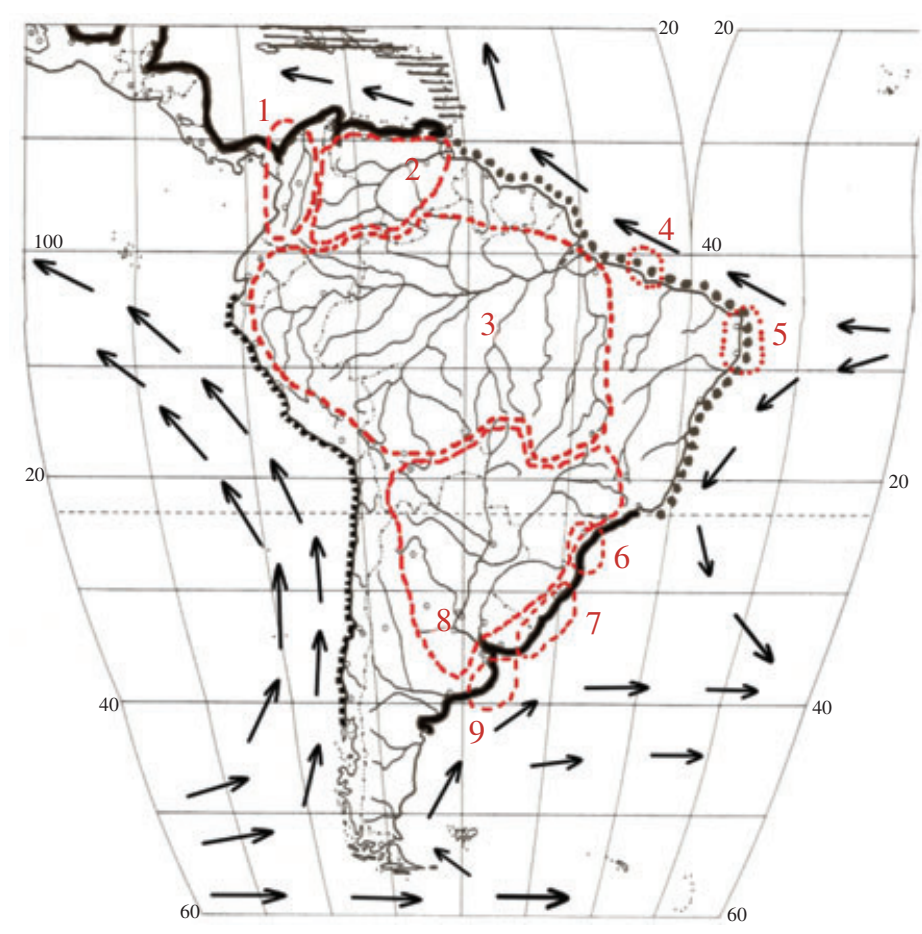

FIG. 1. South American river basins and coastal areas discussed in the present work: (1) Magdalena Basin, (2) Orinoco Basin, (3) Amazon Basin, (4) Caeté River and mangrove coastline, (5) Goiana Estuary and tropical semi-arid eastern coast, (6) Paranaguá Estuary, (7) Patos Lagoon estuary, (8) Paraná-La Plata basin and estuary and (9) south-west Atlantic coastal shelf (SWACS). Main ocean currents are also indicated (source: modified from Briggs, 1996).

to other countries. According to these authors, the decimation of aquatic wildlife through overexploitation is usually perceived as a marine phenomenon, yet it has been common in freshwater ecosystems.

All regions have major water-related issues such as habitat loss and unsustainable exploitation of fisheries resources, especially on the Atlantic Ocean coast. On the Pacific Ocean coast, freshwater shortage was rated as an equally important issue. These threats to fish habitats were similar across the region and encompass freshwater, coastal and marine ecosystems. The degree of habitat loss may vary from hardly detected to severe (Marques et al., 2004; UNEP, 2004a, b, c, 2006a, b, c). Habitat loss may include a number of processes. The leading threats are: river damming for water supply and hydroelectric power generation, dredging, land reclamation, sewage pollution, deforestation and unsustainable land-use practice by agro-industrial business. The Atlantic rain forest has been almost completely replaced by urban areas, sugar cane, coffee, eucalyptus, pines trees, soy beans and pasture land. Riparian vegetation of most river headwaters is not preserved. Consequently, the loss of many riparian habitats is all too common. The Amazon rain forest and other biomes such as Caatinga, Cerrado (Savanna) and Pantanal are also under threat of replacement by the same development pressures, but so far have been preserved by the emerging economic sustainability paradigm. 
One of the major problems facing fish conservation in South America is the lack of basin-wide approaches. Usually, both knowledge and interest are limited to the local, exceptionally to the regional, scale. The South American continent has a number of transboundary water bodies such as natural and artificial lakes, river basins and coastal surface currents. Unfortunately, other investment priorities have removed regional scientific development from the top of the list of priorities. The information available on fish ecology remains sparse, with some basins (e.g. La Plata) and coastal areas (e.g. Patos Lagoon, Guaratuba, Paranaguá, Sepetiba, Goiana and Caeté Estuaries) being favoured to the detriment of others.

Experts agree that fish conservation, not only, in South America will necessarily involve habitat protection, recovery and rehabilitation (Humphries \& Winemiller, 2009). Otherwise, no fisheries or renewable natural resources measures will ever be effective.

\section{CURRENT STATUS OF SELECTED SOUTH AMERICAN RIVER BASINS}

\section{THE MAGDALENA BASIN}

The Magdalena Basin geomorphology has been defined by the uplift of the Andes, the separation from the Orinoco and Maracaibo River basins $>10$ million years ago, and by the regression and transgression of the Caribbean Sea during the Pleistocene. It represents $24 \%\left(257438 \mathrm{~km}^{2}\right)$ of the Colombian territory; its floodplain is c. $12144 \mathrm{~km}^{2}$ (Fig. 1) and it is inundated twice a year. The mean rainfall for the drainage basin is $2050 \mathrm{~mm}_{\text {year }}{ }^{-1}$.

The ichthyofauna in the Magdalena Basin comprises $c .213$ fish species. The basin has a high endemism, a result of the geological history that produced new, isolated, trans-Andean river basins previously interconnected (Maldonado-Ocampo et al., 2008). Although the fish fauna in the Magdalena Basin is the best known in Colombia (Galvis \& Mojica, 2007), there are not much published data on species distributions within the basin.

Total fish landings in the Magdalena Basin represent $55 \%$ of the fisheries production of all Colombian river basins (Orinoco, Amazon and the Pacific lowlands) (CCI, 2007). The main species contributing to this yield are Prochilodus magdalenae Steindachner, Pseudoplatystoma magdaleniatum Buitrago-Suárez \& Burr, Sorubim cuspicaudus Littman, Burr \& Nass and Pimelodus blochii Valenciennes. Fisheries in the Magdalena River have two periods of high yield, resulting from the migration of fishes from the floodplain lakes to the main river because of low water levels caused by the flooding regime. The main fish migration occurs between December and March, and the second between July and August. After these two migrations up the main river channel, mature adults spawn with the first floods and drift with their larvae to the floodplain lakes. This habitat has a nursery and feeding function for these species (Jiménez-Segura, 2007).

\section{Threats to fish and fisheries}

Forty-four fish species from the Magdalena River have been included in the Red Book for Conservation (Mojica et al., 2006). The fish landing in 2008 was $12424 \mathrm{t}$ corresponding to only $16 \%$ of the fish landing of 1975 . Additionally, the captured 
species have also changed. In the 1970s, fisheries were based on piscivorous species such as P. magdaleniatum and Tarpon atlanticus Valenciennes (Galvis \& Mojica, 2007). After their depletion, the fisheries have been focused on detritivorous species as $P$. magdalenae.

The main causes of the fisheries depletion in the Magdalena River are the loss of nursery habitats, which have been converted to farming areas (cattle and agriculture), and high sediment inputs as a result of deforestation. As well as loss of habitats there has been a loss of migratory routes and environmental cues for spawning given by river-course fragmentation, and hydro-geochemical regime change caused by dams and reservoirs. With the introduction of exotic fish species as compensation for the fisheries depletion of the 1970s, the government of Colombia promoted the enhancement of fisheries catches in some reservoirs and the improvement of aquaculture. Since then, at least 90 fish species have been introduced (e.g. Oncorhynchus spp., Tilapia spp. and Oreochromis spp.) or transplanted [e.g. Arapaima gigas Schinz, Cichla ocellaris Bloch \& Schneider, Colossoma macropomum (Cuvier) and Piaractus brachypomum (Cuvier)] to the Magdalena Basin from other freshwater systems or escaped from fish ponds (Alvarado \& Gutierrez, 2002). For some species such as C. macropomum, the statistical landing represents $0.05 \%$ of the total catch in 2006 (CCI, 2007). For that reason, this species may now be considered as established. Contamination of water by mining (mercury) and farming (nitrogen and phosphorous; halogenated hydrocarbons, organophosphates, carbamates and pyrethroids) are the principal threats in this basin (DANE, 2004; CORMAGDALENA, 2007).

\section{THE ORINOCO BASIN}

The Orinoco River receives the waters of $>2000$ tributaries (Mago, 1970) that can be grouped into 23 sub-drainage basins (Fig. 1). More than 990 freshwater fish species have been recorded for the entire basin, but the total is probably near 1200 (Lasso et al., 2004). Rivers draining from the Andes and the Llanos regions are better known than those running from the Guyana Shield. The five sub-drainages with the most species are the Ventuari (475 species.), Delta (448 species.), Apure and Caura (390 species.) and the Aguaro-Guariquito (326 species.) (Lasso et al., 2004).

\section{Fishery resources}

In this basin, the fisheries can be for subsistence, artisanal, sports or for ornamental fishes. Subsistence fishing occurs wherever people live near the water. In the Andean piedmont, there has never been much commercial fishing, but people have always fished for food (Lilyestrom \& Taphorn, 1983; Rodriguez \& Taphorn, 2006). For this basin, Lasso et al. (2004) reported 69 species in the diverse subsistence fisheries, but there would be many more if indigenous peoples such as those living in Canaima National Park were also considered (Lasso, 1989; Lasso et al., 2009).

The commercial fisheries of the Orinoco Basin are concentrated in the floodplains (llanos) and at the delta of Orinoco River. More than 80 species are caught, with emphasis on the prized giant catfishes [Brachyplatystoma spp., Zungaro zungaro (Humboldt) and Pseudoplatystoma spp.] and Prochilodus mariae Eigenmann that are caught during the dry season. The present trend is to capture more P. mariae as the giant catfishes become scarce (Novoa, 2002). The common pattern observed 
in multispecies fisheries is for larger predatory species to decline, and disappear, as they are replaced by less desirable, smaller omnivorous or herbivorous species.

Sport fishing was once popular in several regions of the Orinoco Basin, but because of security issues for ecotourism, it is no longer widely practised. The most sought after species were the peacock basses (Cichla spp.) (Lasso, 2001; Montaña et al., 2007). In many regions, these fishes are overfished by commercial fishers, especially in remote areas near illegal gold mines (Casiquiare, Caura and Caroní) (Rodríguez et al., 2007).

Ornamental fish captures have never been a serious issue in the Orinoco Basin. The few companies dedicated to this activity were not able to withstand the competition and excessive governmental controls that were imposed upon them along with difficulties with export permits (Rodríguez et al., 2007). Today, most ornamental fishes collected in the Orinoco Basin are transhipped to Colombia. Fishers in the ornamental trade are (or should be) natural allies of aquatic ecosystem conservation, since they depend on healthy live fishes for their trade (Chao et al., 2001).

\section{Ecosystem threats}

The Red Data Book for Venezuelan Fauna (Lasso, 2008) lists two Orinoco fish species as 'vulnerable to extinction', Brachyplatystoma juruense (Boulenger) and Sorubimichthys planiceps (Spix \& Agassiz). Another eight species are listed as 'almost threatened', two as 'species of special concern' and one as 'lacking sufficient data' (Lasso, 2008). The threats faced by fishes of the Orinoco Basin are many and diverse. The root of this and all environmental problems is the constant, uncontrolled, growth of the human population and its constantly increasing demand for goods, services and space to live and cultivate food and other agro-industrial products. This ever-increasing demand requires government intervention to undertake expansion of sustainable plans and development to satisfy people's requirements. Several authors have documented the factors that negatively affect freshwater ecosystems of the Orinoco Basin (Machado-Allison, 1994; Winemiller et al., 1996; Allan et al., 2002). The most important effect is urbanization. As far as aquatic systems are concerned, the major effects are from city sewage and urban runoff. Most cities in the Orinoco Basin pour domestic effluents into natural water bodies without any treatment. This problem becomes most critical during the dry season (low waters), when fishes are naturally stressed by less space and warmer waters. When combined with water uptake for crop irrigation during the dry season, many rivers completely dry up, or are reduced to a trickle of highly contaminated water (Winemiller et al., 1996).

Many large infrastructure projects such as navigation canals and dams affect the fishes of the Orinoco Basin. The Guri hydroelectric power plant on the Caroni River has been operating for several decades. It provides electricity to a large portion of Venezuela, but the environmental costs have been high: the Caroni River is no longer a river, but just a canal. These effects have been documented by Álvarez et al. (1986), Castro \& Gorzula (1986) and Taphorn \& García (1991), but little is being done to reduce or mitigate the consequences. Hydroelectric power generation is, when compared to fossil fuels, one of the cleanest ways to generate energy, and when combined with proper catchment management programmes can endure for generations. Unfortunately this is not the case in Venezuela, and the many dammed rivers of the Andean and Guyana Shield regions are subject to excessive sedimentation from poor land and water conservation practice (Winemiller et al., 1996; Machado-Allison, 2007). 


\section{Anthropogenic influences}

In the Orinoco Basin two groups of exotic species of fishes are of special concern: trout [Salmo trutta L. and Salvelinus fontinalis (Mitchill)] and tilapia (Oreochromis spp.). Trout species have been introduced to mountain streams of the Venezuelan Andes and have eliminated other natural fish species (e.g. Astroblepus spp. and Trichomycterus spp.) The piedmont and adjacent plain regions of Portuguesa and Barinas states are affected by mechanized agriculture. In other parts of the drainage basin, the principal land use is cattle ranching. The crops at the higher regions are coffee and bananas; downstream sugar cane, rice, corn and sorghum and, to the east forestry projects. Agricultural production systems require deforestation that causes soil erosion, and the resulting sedimentation damages fish gills and smothers benthic communities. Adult fishes can often swim away to avoid the worst areas, but eggs and larvae succumb. During the dry season, agricultural biocides accumulate in the soil, only to be carried to surface waters with the first rains. Especially toxic are the chlorinated hydrocarbons (e.g. DDT, still in use) heavy metals, lead and mercury. No agency is effectively monitoring this process. Organic and chemical fertilizers with high levels of nitrogen, potassium and phosphates are lost to surface runoff, and eventually make their way into streams and rivers where they cause over-fertilization, eutrophication and consequently dissolved oxygen is further lost from these systems and fishes asphyxiate. Rice and sugar cane require water pumping for irrigation, and natural rivers provide most of the water used in agriculture in the Orinoco Basin. Many rivers now dry up completely during the dry season, due to the combined effects of deforestation and water extraction, even though the law prohibits $>25 \%$ of any watercourse to be so affected.

In the middle and lower Orinoco River, steel mills and other heavy industry are concentrated in Guayana City. These and the petroleum industry, which is widespread throughout much of the llanos, cause a continuous discharge of industrial effluents and occasional spills that affect the fishes of the Orinoco Basin. Effects from oil spills are localized. Oil wells continuously release small quantities of crude to the surrounding area that contaminates soils and water. In Venezuela, the government runs the oil companies, so compliance with environmental law is generally poor. Other latent environmental threats exist in the heavy crude producing regions such as Morichal Largo and the Caris River drainages of the eastern plains. In these regions, salination is occurring because of the process of injection of heated water to allow heavy oils to flow (Colonnello et al., 1985). Residual water contaminated with oil, phenols and heavy metals can percolate back up to contaminate ground water (Machado-Allison, 1994). Oil production also includes its transportation, storage and processing, all of which are hazardous activities for the surrounding aquatic and terrestrial environments when not carried out with utmost care and environmental concern. Coffee is a crop of the piedmont and lower mountain regions, and its processing produces huge piles of discarded coffee bean husks that become a source of organic contamination of mountain streams. One of the principal crops of the llanos is sugar and alcohol cane. Sugar mills and the other plants that use sugar to produce ethanol release large amounts of organic wastes that frequently find their way into streams, where they cause oxygen depletion and toxicity from trace elements and phenols.

Coal and clay mines exist in the Venezuelan Andes, along with numerous sites in river beds where gravel and sand are extracted for building, and all of them increase 
sedimentation and erosion. Coal is associated with sulphur that can combine with water and form sulphuric acid and contaminates streams and ground water. This is particularly pronounced when high pressure water hoses are used to mine diamonds and gold from Guyana Shield rivers such as Caroni, Caura, Ventuari and many others. Mercury used to extract gold particles from sediments is of increasing concern in these regions (Lasso et al., 2006a, b).

\section{THE AMAZON BASIN}

The complexity of the Amazon Basin, which resulted in high fish diversity, is revealed by a myriad of different ecosystems that comprise an almost endless number of rivers, channels, small streams, beaches, flooded forests and várzea lakes (floodplain areas) inside temporary islands (Fig. 1). Also diverse are the types of water that occur in the Amazon: 'white', 'black' and 'clear' waters (Sioli, 1984). They differ in sediment types and contents, dissolved organic carbon (DOC), ion content and other physico-chemical variables such as density, $\mathrm{pH}$ and temperature. These different properties give rise to special phenomena, e.g. those that cause the white and black waters to blend and turn into a homogeneous mixture. Several intermediate water types occur in the whole basin, which, together with the different environments, and under the flood pulse that occurs every year, make these ecosystems one of the most interesting places to investigate the evolution of adaptive traits due to environmental short and long-term changes.

The flood pulses (Junk et al., 1989) comprise annual oscillations of average water levels of $c .9 \mathrm{~m}$ between November (low water and dry season) and June (highest water levels) in the central Amazon. These flood pulses inundate a large area and make several new habitats in the flooded forest and in the floodplain areas available to fishes. Such flood pulses also cause the appearance and disappearance of many other aquatic formations, and during low water levels, the receding water leaves behind small water bodies giving rise to seasonal lakes which are interconnected during the high water. This dynamic environment causes many changes in physico-chemical variables affecting virtually all living organisms (Almeida-Val et al., 1999a). Among these variables, dissolved oxygen has been described by several authors as one important evolutionary force that induced fish adaptations at all biological levels (Val \& Almeida-Val, 1995; Almeida-Val et al., 2000). Past and present patterns of oxygen availability in Amazonian water bodies may be assumed as determinants of selective pressure in the evolution of aquatic life. Hypoxic and anoxic conditions were present in the aquatic environment during the Cambrian period, owing to the low atmospheric oxygen levels at that time (Dudley, 1998). At present, the poorly oxygenated waters of the Amazon Basin result from different phenomena.

Dissolved oxygen in the water bodies of the Amazon Basin usually changes as a result of the interaction of many characteristics and processes such as photosynthesis, respiration of macrophytes and phytoplankton, light penetration, organic decomposition, molecular oxygen diffusion, wind, water-body depth, shape and temperature. Thus, seasonal, daily and spatial variations occur and induce a complex pattern of oxygen distribution in these water bodies. During part of the year, anoxic conditions can be observed at night. During the day, however, oxygen availability increases according to plant cover, depth and period of the day (Almeida-Val et al., 1999a). 
Thus, both long and short-term changes in oxygen may be seen as determinants of fish distribution in the Amazon Basin. Hypoxia tolerance is particularly common in Amazon fishes, and it is believed that such chronic hypoxic environments are the cause of a series of adjustments at all biological levels of organization. These adjustments include behavioural, morphological, anatomical, physiological, metabolic and molecular changes, which are combined to give phenotypic plasticity to fish species allowing them to adapt to the pulsating nature of the basin (Junk et al., 1983; Val \& Almeida-Val, 1995; Almeida-Val et al., 1999a).

The Amazon fish fauna has representatives of almost all freshwater groups occurring in the world (14 orders), and most of them are adapted to low oxygen concentrations in their respective environments (Val et al., 1998). The main strategies can be summarized as follows: (1) obligate air-breathing patterns, (2) facultative air-breathing patterns, (3) aquatic surface respiration and (4) hypoxia tolerance assured by the combination of the anaerobic potential of tissues and organs, and through metabolism suppression. It is important to mention that all strategies involve metabolic and physiological adjustments; some of them due to long-term (evolutionary) changes in structural genes, others due to regulation (up or down regulation) of gene expression (Almeida-Val et al., 1993, 1999b; Almeida-Val \& Hochachka, 1995; Val \& Almeida-Val, 1995; Val et al., 1998). Although much of the attention has been drawn to the oscillations in dissolved oxygen in water, some investigations of the effects of temperature on the metabolism of Amazonian fishes are unavoidable. The main reason is that fishes of the Amazon spend their life at high temperatures and have reorganized their whole metabolism (overall and organ specific) to acclimate to these conditions (Almeida-Val et al., 2006). Investigations demonstrated changes in differential metabolic rates and differential scaling patterns, when fishes of the Amazon River were compared to temperate fish species (Driedzic \& Almeida-Val, 1996; Almeida-Val et al., 2000). The high temperature of Amazon River waters (c. $25-32^{\circ} \mathrm{C}$, maybe higher) contrasts with temperate water bodies, which approach $0^{\circ} \mathrm{C}$ in winter and do not exceed $25^{\circ} \mathrm{C}$ in summer. A life cycle spent at a low thermal regime is often associated with elevated metabolism, e.g. elevated levels of key enzymes of energy metabolism. In contrast to that, fishes living in high temperatures have a lower metabolism, resulting from lower enzyme levels, particularly those associated with aerobic metabolism (Guderley \& Gawlicka, 1992; Johnston et al., 1985; Way-Kleckner \& Sidell, 1985). Furthermore, there is a tendency for increased oxidative metabolism, particularly using fatty acids as main fuels, which allows for meeting the energy demands in low temperature environments (West et al., 1999). In fact, when comparing respiration rates (whole organism oxygen consumption $V_{\mathrm{O}_{2}}$ ) as a function of increased body mass regarding the allometric relationship $V_{\mathrm{O}_{2}}=a M^{b}$, where $a$ is $\log _{10}$ mass coefficient, $M$ is the $\log _{10}$ body mass and $b$ is the mass exponent, there is a clear difference between temperate and tropical fish groups. Variations of $b$ were adopted as described by Wootton (1998) for fishes in general, including Antarctic, temperate and tropical fishes, by Hammer \& Purps (1996) for tropical fishes, and by Almeida-Val et al. (2000) for the anoxia tolerant oscar Astronotus ocellatus (Agassiz). As a result there is a clear trend towards metabolic suppression rates in fishes as they become naturally acclimated nearer the Equator. These data can be seen as an effect of temperature or an adaptive trait to common hypoxic waters occurring in the tropics. In either case, there is good evidence that a metabolic gradient occurs, resulting in a biogeographical pattern associated with 
latitude (Almeida-Val et al., 2006). Metabolic rates of fishes of the Amazon River, particularly the exclusively water-breathing species, vary from sluggish to athletic types. As expected, comparisons between Amazon and north-temperate fish species suggest that the more sluggish a fish is, the less oxygen is consumed per unit mass. Regardless of the high acclimation temperatures, these fishes experience suppressed aerobic capacity, as shown by their aerobic and anaerobic enzyme levels and their metabolic rates (Almeida-Val \& Hochachka, 1995; Driedzic \& Almeida-Val, 1996; West et al., 1999).

Currently, the two major concerns regarding Amazon fishes are global warming and the speed with which hypoxia is spreading globally throughout water bodies as a result of pollution. In the Amazon River, the effects of global warming have been reflected in annual rhythms of flood pulses causing extremely strong droughts, as in 2005, and severe inundations as in 2009, when the highest water level ever registered in the Negro River, was caused by intense rain in the headwaters of the entire basin. Along with these phenomena, fish assemblages may be affected since the system is disturbed and unusual changes in dissolved oxygen, temperature and other variables may cause differential responses from different species. Considering the depletion in oxygen availability (hypoxia) the situation is even more complex. As already mentioned, hypoxia is a natural phenomenon in the Amazon Basin and has imposed so many pressures throughout evolution that most fish groups developed a dependence on surface waters. Originally, however, healthy environments have been transformed into poorly oxygenated waters due to excessive anthropogenic input of nutrients and organic material. In addition, some chemical pollutants associated with the modern way of life, including polymers, metals, petroleum, aquaculture nutrients, pesticides and herbicides, will continue to present new metabolic challenges to fishes of the Amazon River (Almeida-Val et al., 2006). Intensive farming, application of fertilizers, deforestation and discharge of domestic and industrial effluents are coincident with human population growth as well as with urbanization. Thus, organic pollution and hypoxia caused by eutrophication are now considered to be among the most pressing water problems in the world (Val \& Almeida-Val, 1999; Wu, 2002).

Oil pollution is also a concern in the Amazon River. Large reserves of oil have been found in the basin, and oil and gas are currently being extracted near the Urucu Basin, a tributary of the Amazon River. The oil is transported in tankers across the Amazon River to the refinery located in Manaus. Although safety procedures are observed, the risk of an oil spill in rivers of the Amazon Basin exists. The effects of an oil spill on freshwater habitats are poorly known since most data on the effects of oil spills are from marine habitats and terrestrial environments. In water, the fractions of crude oil have different effects on fishes; the water soluble fraction, composed of aromatic hydrocarbons, also includes metals and is among the most hazardous fraction to organisms. Other fractions include short-chain hydrocarbons that are volatile and short lived in the water. The third component of crude oil is a large amount of long-chain hydrocarbons and these are the ones that stay much longer on the top of the water column and pose a barrier at the air-water interface, observed as an oil slick. The dependence of fishes of the Amazon River on the water surface during episodes of hypoxia disadvantage them in the case of an oil spill (Val, 1996, 1997; Val \& Almeida-Val, 1999; Matsuo et al., 2005). In fact, a series of adjustments and responses of fishes to crude oil exposure has been observed. Most obligatory and facultative air-breathing fishes, as well as aquatic surface respiration species 
(ASR), have their blood oxygen content almost completely depleted when exposed to oil spills. Moreover, their methaemoglobin (non-functional haemoglobin) levels increase, and their metabolism changes to combat reactive oxygen species that are generated in excess when fishes are exposed to oil fractions. During exposure, the levels of antioxidant enzymes increase as well as the detoxifying processes, which compensates for the aggressive damage produced in animal tissues and cells (Val \& Almeida-Val, 1999).

\section{Fish ecology}

The prevalence of Characiformes in the composition and structure of the ichthyofauna of lakes of the middle Amazon River is well established (Junk et al., 1983; Soares et al., 1986; Petry et al., 2003), as well as the seasonal changes related to variations in river flow. Siluriiformes and Gymnotiformes prevail in river habitats (Merona, 1987; Cox-Fernandes et al., 2004). Larger geographic patterns, however, have already been detected. Inflows to the Amazon River contribute to Gymnotiformes diversity and increase at the main channel downstream from the confluences (Cox-Fernandes et al., 2004); another example is higher richness, diversity and abundance of demersal fishes of the Amazon and Negro Rivers at depths $<10 \mathrm{~m}$, and the gradual decrease of such variables with increasing depth (Barletta, 1995; ThoméSouza \& Chao, 2004). Looking at the Amazon River more broadly, however, shows that sound scientific information about fishes within the flooded forest is relatively restricted. Difficulties arise not only from surveying large areas but also, and mainly, from the diversity of habitats and species diversity. Even now, it is still true to say that there are large knowledge gaps to be filled in order to understand the general patterns of distribution and species, populations and community interrelations (Santos et al., 1991). As expected, large fishes of commercial interest concentrate the attention of scientific studies, while smaller species which constitute the vast majority of the biomass are neglected. The concentration of efforts around commercial species has resulted in a significant knowledge (biology and fisheries) of only 20 of the 80 exploited species of the middle and lower Amazon River.

The floodplain of the Amazon River and its tributaries is a complex network of channels, ephemeral lakes (Quaternary terrains) and proper lakes (on Tertiary areas). Habitat diversity across the flood plain undergoes dramatic changes both horizontally and vertically, according to water level and sediment dynamics. The environmental dynamics determine extreme conditions to the fish fauna, promoting wide swings in oxygen levels, and availability of food, shelter and breeding grounds. Fishes that depend upon the seasonal colonization of the flooded forest or floodplains are dominant in local landings in terms of biomass (Junk et al., 1989).

\section{Fish species and habitats connectivity}

Environmental characteristics, longitudinal and lateral movements of fishes were combined to establish three management categories for fishes in the Amazon Basin: (1) sedentary species, (2) migratory species that use the flooded forest during some part of their life cycle and (3) migratory species that perform long-distance movements (Lowe-McConnell, 1987). For each group, a particular management strategy incorporating an ecosystem approach was proposed by Barthem \& Fabré (2004). 
The species-habitat concept can be related to evolutionary life strategies. A triangular model to represent life strategies (Kawasaki, 1980) was applied to fishes in Venezuela and North America (Winemiller, 1989; Winemiller \& Rose, 1992). This model predicts three life strategies for fishes: (1) periodic $\left(r_{2}\right)$, high fecundity, seasonal reproductive cycle, no parental protection, minimum sexual maturity after at least 1 year, medium average life expectancy, low juvenile survival and high adult survival rates, large population densities fluctuations; (2) equilibrium ( $k$ ), low fecundity, large eggs, parental protection, late reproduction, iteroparity, high juvenile and adult survival rates, high life expectancy, stable population densities; (3) opportunistic $\left(r_{1}\right)$, low fecundity, annual cycle, no parental protection, iteroparity, low juvenile and adult survival rates, small size and variable population densities. In the Apuré River (Orinoco Basin, Venezuela), 63\% of the species in the flooded forest assembly were $r_{2}$, among which $40 \%$ were migratory. In the $k$ group, only $15 \%$ were migratory species.

The fish assembly of 36 lakes in the flooded forest between Santarém and Tefé (1570 km) was studied, and from 194 species, 43 performed short-distance movements (Granado-Lorencio et al., 2005).

\section{The lacustrine species}

In the central Amazon River, there is a prevalence of $k$-strategy (54\% of species), but a high percentage $(42 \%)$ of species with periodic strategy also occur. These species may be associated with lake environments, but are not necessarily sedentary as originally proposed. Some species have limited movements, e.g. cichlids, that deposit their eggs on the bottom and both parents share their care and continue for weeks after hatching (Kullander, 2003).

Lake species have a maximum total length $\left(L_{\mathrm{T}}\right)$ of $20-200 \mathrm{~cm}$ and develop their entire life cycle in flooded environments with similar limnological characteristics. These species perform daily or seasonal movements at a local scale $(1-5 \mathrm{~km})$ in order to use different lakes or flooded environments. This is the case for A. gigas, a $k$-strategist that performs lateral movements among habitats of the flooded forest (Castello, 2007). The movements of this species cover two different groups of habitats: one among flooded areas have trophic and reproductive functions and differ from the movements among other sets of habitats during the dry period, when they look for favourable conditions for survival. Hoplias spp. is a second example of a fish species that uses different habitats of the flooded forest by performing shortdistance movements to breed and to promote separation of juveniles and adults in different areas (Winemiller \& Jepsen, 1998). These movements were also observed in the Orinoco River and were attributed to trophic interactions that may be affected by seasonal shifts in flooded areas. Lake species of the Amazon Basin perform seasonal movements and along their paths they explore and use different habitats of the flooded forest (Dingle \& Drake, 2007). The seasonal flood and draught, however, cyclically and gradually modify (create and destroy) these habitats used by fishes.

Of the lake fisheries' species, $48 \%$ of these are from the middle and lower Amazon River discussed here, and 57\% adopt an equilibrium strategy. Their capacity for stock replenishment is lower than the resilience of the habitats that they need in order to complete their life cycles, this indicates the fragility of these species which live in Amazon River lacustrine environments. 


\section{Lacustrine-riverine species}

Species in this group are medium-sized $\left(20-60 \mathrm{~cm} L_{\mathrm{T}}\right)$, except for $C$. macropomum (maximum $L_{\mathrm{T}} 120 \mathrm{~cm}$ ). This group uses lakes and the main channel of rivers to complete their life cycle. Their movements are seasonal and associated with the water level in the river. Usually species from this group cover 400-500 km to breed, feed or disperse. All species in the group have a periodic strategy and are represented by species from the families Anastomidae, Characidae, Hypophthalmidae, Myleidae, Prochilodontidae and Pimelodidae.

The characid, C. macropomum, stays in the lakes and flooded forest for 5 years before moving for the first time into rivers to reproduce (Araújo-Lima \& Goulding, 1998). Adults usually use lakes and the flooded forest to feed on seeds and return to the rivers to breed. Semaprochilodus insignis (Jardine) and Semaprochilodus taeniurus (Valenciennes) (Prochilodontidae) spend 6-8 months in lakes during flood. They feed and grow rapidly and subsequently move to tributaries to disperse (Ribeiro \& Petrere, 1990). Similar movements are described for Prochilodus nigricans Spix \& Agassiz (Barthem \& Fabré, 2004) and Brycon amazonicus (Spix \& Agassiz) (Zaniboni-Filho, 1985). These species are intensely fished during their dispersion movements. Since shoals are mainly juveniles of not more than 1 year and young adults (2-3 years), these species are under threat of overfishing.

Records of age and growth rates of lake-river fish species suggest a strong correlation between movements, habitat use and seasonal biological processes such as breeding and feeding. Semaprochilodus insignis and S. taeniurus have two growth marks per year, one relative to the drought when they perform movements of dispersion, and another relative to the flood when they move for feeding and reproduction (Barthem \& Fabré, 2004). The same pattern was observed for P. nigricans (Oliveira, 1997) and B. amazonicus (Villacorta-Correa, 1987). High growth rates and double marks on calcified structures were also found in Pimelodidae, e.g. Calophysus macropterus (Lichtenstein) (Perez \& Fabré, 2003) and Hypophthalmus marginatus Valenciennes (Santos-Filho \& Batista, 2005).

Shoals of lake-river species move on a regional scale, promoting the redistribution of individuals upstream. Their second movement is for breeding, and is downstream, searching for water mixtures (white with black or clear water) at the end of the drought. Juveniles and adults use the flooded plains to feed and in this manner reduce juvenile mortality by exploring and using flooded forest environments to feed whenever they are available without the need to invest in parental care. These movements differ from those proposed for lake species since they depend fundamentally on the predictable rhythm of the flood pulse, in accordance with a periodic strategy (Winemiller \& Rose, 1992).

Fisheries monitoring on the Amazon River show that this group of fish species comprises at least $77 \%$ of the landings. The conservation of these species is also closely related to the conservation of the flooded forest, with special concern for the routes taken by these fishes to move and disperse between lakes and rivers.

\section{Riverine species}

River species are the large Pimelodidae $\left(80-200 \mathrm{~cm} L_{\mathrm{T}}\right)$ that chiefly inhabit the main channel of the Amazon River and its tributaries. They can move $>1000 \mathrm{~km}$. So far, only three species are placed in this group: Brachyplatystoma rousseauxii (Castelnau), Brachyplatystoma vaillantii (Valenciennes) and Brachyplatystoma platynemum 
Boulenger. The three species are periodic strategists, and use the flooded plains during the adult phase, depending upon this habitat to feed on medium-sized fishes that move from one habitat to another during drought (Angelini et al., 2006). Brachyplatystoma rousseauxii and $B$. vaillantii may move $>3000 \mathrm{~km}$ to feed and reproduce, from the Andes to the Amazon Estuary (Carvalho \& Fabré, 2006). The life cycle of both species involves four major steps that take place from the estuary to the upper Amazon Basin. These species, populations are characterized by an age (and therefore size) class structure (Alonso \& Picker, 2005). Juveniles (c. $20 \mathrm{~cm} \mathrm{B.} \mathrm{vail-}$ lantii and c. $40 \mathrm{~cm} \mathrm{~B}$. rousseuaxii) are found in the estuary and in flooded forest lakes. When these young complete $2-3$ years $(c .20-40 \mathrm{~cm} \mathrm{~B}$. vaillantii and $c$. $40-80 \mathrm{~cm} \mathrm{~B}$. rousseuaxii), they start to move upstream. Adults ( $>40 \mathrm{~cm} \mathrm{~B}$. vaillantii and $>80 \mathrm{~cm} B$. rousseuaxii) reach the upper course of white-water rivers to spawn, a journey that can stretch $>3000 \mathrm{~km}$ in spite of the different rhythms of the two species. For $B$. rousseuaxii, a change in population structure is evident from the estuary to the upper river course. Young migrants prevail up to $1200 \mathrm{~km}$ from the estuary, which in the case of the Amazon River corresponds to the confluence with the Madeira River and the Purus River. After $1800 \mathrm{~km}$ upstream from the river mouth, adults comprise at least $70 \%$ of the population. At $c .3000 \mathrm{~km}$ from the estuary, only adults can be found (Fig. 1).

It was suggested that there is only one single population of B. rousseauxii and B. vaillantii (Barthem \& Goulding, 1997), spanning in the whole basin. Genetic studies using mitochondrial DNA have shown that $B$. vaillantii has no preference for the river channel to reproduce, in contrast with B. rousseauxii that prefers the Amazon River system when compared to other tributaries (Batista \& Alves-Gomes, 2006). From the genetic and population dynamics point of view, there is a single population of both these large migrant species in the Amazon River. Recruitment occurs mainly in the upper course of white-water rivers (e.g. Madeira, Juruá, Purus, Içá and Japurá Rivers). Moreover, these species are fished along the entire system where they occur, even up to Iquitos in Peru. Total fisheries yield per year is c. $18600 \mathrm{t}$ for B. rousseauxii and $14100 \mathrm{t}$ for B. vaillantii (Fabré \& Barthem, 2005). Therefore, all size classes, including juveniles are exploited, which explains the signs of overfishing already detected (Alonso \& Picker, 2005). In addition, dams for hydroelectric power generation may cut the migratory routes, posing an extra threat to these species.

Fishes are the most studied taxonomic group in the Amazonian region, but even so, their ecological patterns (seasonal and spatial movements) are still not fully known. The effects of connectivity between lakes and rivers of the Amazon region on the structure of fish assemblages are a key study subject (Granado-Lorencio et al., 2005). In addition to connectivity, limnological variables are also responsible for explaining fisheries yields (Nolan et al., 2009). Hence, it is possible to hypothesize that fish species composition and abundance depends upon environmental variables of the flooded forest habitats and their seasonal shifts. According to Petrere (1983), the extension of the flooded forest areas can explain the fisheries yields of the Amazon Basin, but the role of habitat diversity for fisheries production within these ephemeral water environments is unknown. 


\section{LA PLATA BASIN}

The La Plata catchment comprises an area drained by the Paraguay, Paraná and Uruguay Rivers ending at La Plata River and a wide estuary (Fig. 1) (Bonetto, 1998). Flood pulses, as in other neotropical river basins, are a critical component of the integrity of floodplain rivers and define a suite of important ecological processes related to nutrients, biota and hydrological conditions which link the terrestrial and fluvial landscape (Junk \& Wantzen, 2004). In addition, connectivity plays a major role in structuring fish assemblages (Paully \& Rodriguez, 2004), influencing $\beta$ and $\gamma$-diversity in river floodplains (Arrington \& Winemiller, 2004). In the Paraná River, DOC represents the most important carbon source (Depetris \& Paolini, 1991) and as the flood pulse recedes, floodplain DOC, particulate organic carbon (POC) and nutrients represent a valuable source for biotic communities and a key mechanism for supporting the overall sustainability of the system. Such features have been reported for the lower Paraguay and middle Paraná Rivers (Carignan \& Neiff, 1992) and are strongly related to fish population dynamics. Fish abundance is dominated by small size species, including juveniles of migratory species (Bonetto et al., 1965; Oldani, 1990) where fish biomass can reach up to $2000 \mathrm{~kg} \mathrm{ha}^{-1}$ (Pignalberi de Hassan \& Cordiviola de Yuan, 1985). These lagoons are also inhabited by juveniles of migratory species such as Prochilodus lineatus (Valenciennes), Piaractus mesopotamicus (Holmberg), Salminus brasiliensis (Cuvier) and Leporinus obtusidens (Valenciennes), thus reflecting their ecological importance as nursery and recruitment areas.

\section{Fish ecology}

The La Plata Basin includes fishes from the upper Paraguay and Paranoplatense zoogeographical provinces (López et al., 2002; López \& Miquelarena, 2005). Based on presence of endemic fish species and environmental characteristics, this basin can be divided in three ecoregions (subtropical Potamic Axis, Oriental Paraná-Platense and lower Uruguay River). These rivers support large migratory fishes that exhibit a dominant potadromous life-history strategy, all being iteroparous. According to Agostinho et al. (2003), the migratory fishes represent $21 \%$ of fish abundance in neotropical rivers that have floodplains.

These migratory fishes can perform reproductive movements $>1440 \mathrm{~km}$ along the Paraná River or between the Uruguay and Paraná Rivers moving up to $1100 \mathrm{~km}$ (Sverlij \& Espinach Ros, 1986; Sverlij et al., 1993). Most of the available information has been gathered from $P$. lineatus by studying its movements in the Paraná River and secondary channels (Bonetto \& Pignalberi, 1964; Bonetto et al., 1981), in the Bermejo River (Bonetto et al., 1971), in the Uruguay River (Delfino \& Baigún, 1985; Espinach Ros et al., 1998) and in La Plata River (Bonetto et al., 1971). Migratory movements comprise ascending displacements for spawning during spring and summer in the middle and high Paraná, and for trophic purposes descending movements to the lower areas of the Paraná, Uruguay and La Plata Rivers (Sverlij et al., 1993).

Among the exotic species, Cyprinus carpio L. is considered the most abundant in the basin. Acipenser baerii Brandt, Morone saxatilis (Walbaum), Tilapia zilli (Gervais) and Micropterus salmoides (Lacépède) have also been occasionally reported in the Paraná and Uruguay Rivers. 
The La Plata Basin provides almost $90 \%$ of continental fish production for Argentina, Uruguay and Paraguay, and encompasses different fishery regions based on geomorphological and hydrological characteristics (Quirós, 2004). Small-scale artisanal fisheries are based on $c$. 20 species for which minimum size limit regulations, sometimes different among provinces or countries, have been imposed as the only regulatory framework (Filippo, 2008). Historical records (1935-1983) have been analysed by Quirós \& Cuch (1989) and Quirós (1990) who noted that catches of Siluriiformes predominated in the lower Paraguay and middle and upper Paraná Rivers, whereas $P$. lineatus represented the main species captured from the middle portion of the Paraná River to the La Plata Estuary. Quirós \& Cuch (1989) estimated a mean annual catch of $11900 \mathrm{t}$ for the $1945-1984$ period (73\% of the total catch comprised $P$. lineatus).

The upper Paraná River, influenced by the Yacyreta Dam, shows different fishing areas. Upstream of the reservoir commercial fisheries were strongly depleted 5 years after its construction by the reduction of large migratory fishes, which were almost unable to pass the dam (Oldani \& Baigún, 2002). In this region, landings decreased from 2500 to $3000 \mathrm{~kg}_{\text {fisher }}{ }^{-1}$ year $^{-1}$ to $500 \mathrm{~kg} \mathrm{fisher}^{-1}$ year $^{-1}$ after dam construction (Espinach Ros \& Fuentes, 2000). In the Yacyreta Reservoir, changes in environmental conditions shifted the fisheries focus to smaller and less valuable species such as Hemiodus orthonops Eignman \& Kennedy, Pachyurus bonariensis Steindachner and Trachydoras paraguayensis (Eigenmann \& Ward), after the trophic phase ended (Baigún \& Oldani, 2005).

The Paraguay-Paraná-La Plata axis shows a heterogeneous profile of target species according to their relative commercial importance. The lower Paraguay River fisheries are characterized by the catch of large Siluriiformes and omnivorousfrugivorous species, and the fishery is expanding (Espinach Ros \& Delfino, 1993). Although the mean sizes of main target species are still greater than length of first maturation, the absence of regular trophy sizes suggest that the fishery is entering a moderate to high development phase. In turn, at the Paraná-Paraguay confluence, mean sizes of commercial and recreational species such as $P$. lineatus, Pseudoplatystoma spp. and Luciopimelodus pati (Valenciennes) still remain high and even over critical length (J. Bechara, F. Vargas \& C. Flores-Quintana, unpubl. data).

Historically the lower Uruguay River has supported an important fishery based on P. lineatus, which yield up to 4500 t between 1945 and 1998 (Espinach Ros \& Fuentes, 2000). In the same vein, in La Plata River (freshwater sector) P. lineatus fisheries were very significant during most of the 20th Century reaching up to $12000 \mathrm{t} \mathrm{year}^{-1}$ and averaging 4000-5000 t year ${ }^{-1}$ between 1930 and 1980 (Baigún et al., 2003). This is the only fishery in the basin that operates with small vessels (10-16 m) (Espinach Ros \& Fuentes, 2000). At present, these fisheries are restricted to only a few small areas on the Uruguayan coast where other species such as S. brasiliensis, Odontesthes spp. and L. obtusidens become seasonal targets.

A distinctive feature of the La Plata Basin is the importance of recreational fisheries. Although target species comprise c. 30 species, most anglers are oriented to the capture of large top predators [L. pati, Pseudoplatystoma fasciatum (L.), Pseudoplatystoma corruscans (Spix \& Agassiz), Zungaro jahu (Ihering), Platystoma luetkeni (Steindachner), Hemisorubim platyrhynchos (Valenciennes), Sorubim lima (Bloch \& Schneider), Hoplias malabaricus (Bloch), S. brasiliensis] and omnivorous-frugivorous species [L. obtusidens, P. mesopotamicus and Brycon orbygnianus 
(Valenciennes)], most of which are migratory. The effects of the recreational fishery are still unknown, but could be important due to the large number of anglers. Since most of these species also became targets for the commercial fishery, conflicts based on regulations and allocations of fishing areas are not uncommon (Baigún et al., 2003).

Ornamental fisheries remain almost unregulated and not quantified, and include several species mostly of small size captured with beach seines in floodplain lagoons and marshes. The most common ornamental fish species include Crenicichla spp., Geophagus spp., Austrolebias spp., Gymnotus carapo L., Apteronotus albifrons (L.), Thoracocharax stellatus (Kner), Hyphessobrycon spp., Moenkhausia spp., Otocinclus spp., Serrasalmus spp., Paraloricaria spp. Loricariichthys spp. and Hypostomus spp. and are captured for aquarium purposes (Gómez et al., 1994).

Industrial pollution, urban sewage, mining, water diversion, deforestation and flow regulation by dams are the main factors influencing fishes and fisheries directly or indirectly (Bonetto, 1998). For instance, the upper Paraná Basin has lost 80-90\% of forest cover in the last 50 years (Tucci \& Clarke, 1998), whereas change in land use from natural forest to cropping systems based on soybean production has increased sediment and pollutant inputs, changing water quality. In addition, river regulation by chained dams has sequestered nutrients and organic matter adsorbed to sediments. Development of large hydroelectric power plants and then dams, mainly in the upper Paraná Basin (Brazil), is influencing the river flow regime particularly during dry periods (Baigún et al., 2010). River regulation in the Paraná Basin has been considered to be one of the primary factors reducing fish diversity (Agostinho \& Gomes, 1997). The lower portion of this basin has fewer dammed river stretches. This situation could change in coming years if several dams projected for the Parana and Uruguay Rivers are built. With the construction of the Yacyreta (upper Paraná River) and Salto Grande (lower Uruguay River) dams, several important lessons regarding fish conservation, fisheries and mitigation actions were learnt. In the Yacyreta dam, fish passages (elevators) were effective for small migratory species (Pimelodus maculatus Lacépède). Despite using the Borland lock type, the Salto Grande dam was unfortunately no exception to the rule and its fish passage is also more efficient for small migratory species [Auchenipterus nuchalis (Spix \& Agassiz), Parapimelodus valenciennesi (Lütken) and Lycengraulis grossidens (Agassiz)] (Espinach Ros et al., 1998). Other effects such as drainage for waterways, dykes, irrigation and levee construction, water pumping for rice farming, industrial and domestic sewage contamination represent causes of a decline in ecological integrity. The Paraguay-Paraná waterway may represent a major threat reducing the flooded area, particularly during the dry seasons (Hamilton, 1999). The La Plata River is heavily polluted, acting as a sink of fine contaminated sediments drained by the basins of the Paraguay, Paraná and Uruguay Rivers. Heavy metals and organic pollutants are easily incorporated into the trophic chain by bioaccumulation through detritivirous fishes such as P. lineatus, Loricaria spp. and Hypostomus, spp. (Colombo et al., 2000). In addition, it is necessary to assess how present and future projects (e.g. dams, dykes, water channel diversions and waterways) could affect environmental integrity and mitigate the changes caused. 


\section{Fish biodiversity conservation and fisheries sustainability}

Fish conservation guidelines in the lower La Plata Basin are poorly developed and regional Red Lists of Threatened Species are still lacking or imprecise. Recently, applying IUCN global criteria (Baillie et al., 2004), c. 200 species were assessed for the lower basin with 11 considered as threatened (eight vulnerable and three endangered) (Sub-regional Assessment Workshop of La Plata Basin fish: Paraguay and Argentina, Asunción, Paraguay, August 2008). The increasing importance of artisanal, commercial and recreational fisheries in the lower basin is challenging managers to apply sustainable management strategies to protect migratory stocks, but other species that also strongly contribute to biodiversity and may play critical ecosystem roles have not been properly considered. Conservation of migratory stocks should be established as a key priority for maintaining fishery sustainability and fisher livelihoods. New paradigms are required to maintain healthy fish communities and to conserve and achieve sustainable fisheries. Integrating such perspective into management advice and ecosystem objectives, the La Plata Basin still offers the outstanding opportunity for re-examining critical concepts and management actions, often derived from the marine environment, such as the meaning of overfishing in the light of the unique characteristics presented by large river fish communities. In Table I some major issues and strategies that need to be considered to maintain sustainable fisheries in the long term across the lower La Plata Basin are listed.

In conclusion, the La Plata Basin is confronted with important changes derived from accelerated changes in land and water use, which will affect their fish communities and fisheries. Although high diversity and healthy fish communities with trophy-sized fishes are observed for most of the lower basin rivers, some typical indicators of resource degradation are being identified. Species disappearance from several areas, mean size reduction, increasing conflicts between fishers, delay in incorporating ecosystem approaches into management plans, deficient fishing regulations, rising of commercial fishing pressure, declining of flood pulse intensity, industrial and agriculture pollution, ongoing floodplain occupation and changes in land and water use across the overall basin are some of the main concerns that should be assessed and integrated into fishery management frameworks. Construction of dams planned for the Paraná and Uruguay Rivers will promote irreversible changes in fish assemblages reducing migratory stocks and thus affecting fishers' livelihoods. Decreasing flood pulses will isolate critical rearing, nursery and feeding habitats located in secondary channels and floodplain areas affecting overall fish production. Promotion of intensive commercial fishing should be balanced in terms of socio-economic and ecological benefits and costs. The dam development and river fragmentation of the upper and middle Paraná Basin (principally in Brazil) have resulted in decreasing fisheries quality due to a reduction of migratory stocks and critical habitat losses (Agostinho et al., 2007a) New paradigms are needed to conserve the La Plata Basin resources in the face of expected new climate scenarios and increasing human intervention. Resource management in large rivers should be envisioned within an ecosystem approach to fisheries (Garcia et al., 2003), but adapted to large river ecological characteristics. Pervasive paradigms derived from marine environments directed to achieve maximum sustainable yield and economic benefits as main goals are inappropriate for large rivers where other objectives become relevant as well. It is important for the managers to understand that specific properties of large rivers were not found in marine environments (e.g. flood pulses and 
TABLE I. Main constraints and limitations observed in the lower La Plata Basin for sustainable fishery management practice and proposed tools

Constraints Technical tools

Transboundary stocks

Lack of appropriate statistical fishery records

Top-down and highly centralized management structures

Conflicts among artisanal, industrial and recreational fisheries

Open access resources

Poor or incomplete scientific knowledge of fish bio-ecological characteristics

Limited fishery information

Few and single species assessment models

Old, inappropriate or incomplete fishing regulations

Weak or few governmental fishery management agencies, lacking enforcement power and poor technical capability

Incompatible land and water resource use and management to maintain fish biodiversity and sustainable fisheries high at local, regional or even basin scale

Lack of reliable management plans applicable at different spatial scales
Integrate management policies across socio-economic and ecological areas

Design reliable fishery information systems to acquire critical in situ (landings) and ex situ information (markets)

Develop more participative and transversal administrative systems promoting co-managed fisheries and new governance practises

Apply temporal and spatial fishing regulations including gear types, mesh sizes, size limits, closed seasons, catch limits and reserve areas

Consider fishing right assignments to groups or communities

Improve key scientific information mostly directed to develop management tools

Developing a reference point system and identify indicators of fishery sustainability, applying meta-information-based tools and expert knowledge

Develop multispecies models integrated into an ecosystem approach to fisheries management

Promote regulations based on an ecosystem approach using floodplain-river structure and processes as adjusted principles as well as species biological criteria

Create or strengthen economic, logistic and human capacities by upgrading agency status according to fishery importance or conflicts

Develop ordination measurements identifying and integrating those activities and processes that may affect river ecological integrity

Develop comprehensive fishery ordination frameworks comprising social, economic and ecological components

floodplain connectivity, strong importance of migratory stocks, smaller population sizes and large source of effects even at a basin scale) and societal benefits derived from goods and services strongly depend on maintaining ecological integrity and become key factors to assure long-term fisheries sustainability. Such management approaches are also relevant to expected climatic changes in the basin that could modify abiotic characteristics and key biotic communities. 


\section{EFFECTS OF IMPOUNDMENTS ON THE FISHES AND FISHERIES OF SOUTH AMERICA}

The damming of rivers to form large reservoirs for hydroelectric power generation have altered the hydrology of most South American river basins. There are $>900$ large reservoirs in this region that cover $>40000 \mathrm{~km}^{2}$; the majority are located in the eastern half of Brazil (Agostinho et al., 2007b). Some important river basins, such as La Plata, São Francisco and Tocantins, have few undammed stretches and illustrate the most extreme cases of habitat modification in the region. The increased demand for electric power, the option to produce it via hydro sources and the shortage of new potential of existing large water bodies, has recently increased interest in exploiting new possibilities in western Brazil and in small rivers. In addition to the recognized importance of reservoirs in economic development, it is widely held that they result in irreversible alterations, including marked environmental and social changes. The hydrological regime of rivers affects the quality of habitats and the functioning of ecosystems. The most noticeable effect of dams on the ichthyofauna occurs with respect to migratory species. Entire populations (even species), which can be affected by processes of river fragmentation can have their access to spawning and nursery habitats blocked. Such issues lead to serious genetic consequences and affect the intensity of recruitment (Petrere, 1996). Equally harmful are the effects of river flow control, and the retention of nutrients and sediments to the downstream stretches, especially when the affected area is a floodplain. River flow regulation affects the connectivity of river-floodplain systems, reducing the availability of critical habitats for the development of fishes and affecting recruitment, particularly of migratory fishes (Junk et al., 1989; Agostinho et al., 2004; Thomaz et al., 2007). Retention of nutrients impoverishes the river floodplain leading to decreased fish productivity (Kobayashi et al., 2008; Roberto et al., 2009). In addition, retention of sediments increases transparency and the erosive capacity of water, changing habitats (Souza-Filho et al., 2004), trophic relations (Abujanra et al., 2009; Luz-Agostinho et al., 2009), intensity of predation on eggs and larvae (Agostinho et al., 2007b), persistence of species (Gubiani et al., 2007) and aquatic vegetation (Zimmer et al., 2003; Thomaz et al., 2009).

\section{FISH SPECIES COMPOSITION AND LIFE-CYCLE STRATEGIES}

Insufficiency of surveys and the need for taxonomic revisions of several groups leads to inaccurate estimates of fish diversity in the continental waters of Brazil (Agostinho et al., 2008). In the Paraná Basin, where most of the South American research institutions and ichthyologists have historically been based, the number of species described in the current decade presents an exponential trend and it is the highest since 1758, when Linnaeus performed the first descriptions (Langeani et al., 2007). In the Iguaçu Basin, which is $>1000 \mathrm{~km}$ in length and in which more than half of the species are endemic, the most abundant species still need accurate descriptions. Even considering the incipient state of knowledge on the richness of freshwater neotropical fish species, the present figure represents $28-31 \%$ of the fish species currently known on Earth (Reis et al., 2003a, b; Lévequè et al., 2008). The fauna in this area are essentially composed of Characiformes (41\%) and Siluriiformes (45\%), as well as Gymnotiformes (3\%), Perciformes (Cichlidae) (4.5\%) Cyprinodontiformes 
(3.5\%) and some marine families endemic to fresh water (1.8\%): Potamotrigonidae, Soleidae, Clupeidae, Engraulidae, Sciaenidae and Belonidae, among others. In addition, there are some less-represented families, such as Osteoglossidae and Lepidosirenidae (Lowe-McConnell, 1987; Moyle \& Cech, 1996; Agostinho et al., $2007 a$ ). Within the home range of neotropical species, different species can be classified from sedentary to long-distance migratory, with the majority falling in between the gradient of these two extremes (in particular, short-distance migratory). The first group typically includes species that develop parental care, internal (or eventually external) fertilization, but with a restricted displacement, such as cichlids, most loricariids, gymnotids, some Characiformes and Siluriiformes (Agostinho et al., 2004). Long-distance migratory forms include the larger species of Characiformes and Siluriiformes. Migratory fishes comprise $>15 \%$ of the total neotropical ichthyofauna. They exhibit the largest home ranges, including spawning and nursery habitats, up to $4000 \mathrm{~km}$ apart (Barthen \& Goulding, 1997). Their reproduction and recruitment are controlled mainly by the seasonality of the hydrological regime (Lowe-McConnell, 1987; Winemiller, 1989; Bailly et al., 2008), as evidenced by the synchrony between floods and the events of the reproductive cycle (maturation of oocytes, migration, spawning and initial development of the progeny). Another noticeable correlation is between the success of recruitment and the attributes of the hydrological regime (Bailly et al., 2008; Fernandes et al., 2009; Suzuki et al., 2009). Dams may block the movements of migratory fishes between critical habitats needed to complete their life cycle. In addition, dams artificially control the seasonal flooding regime. Alteration of these rhythms leads to differences in water quality and decreased availability of critical habitats. Thus, dams are one of the most important threats to habitat conservation and the maintenance of migratory fish populations. The disappearance of large migratory species in some rivers in the upper Paraná Basin, where there are $>140$ dams, is an example of this problem (Lowe-McConnell, 1987).

\section{FIS HERIES}

Before the impoundment of large areas in South American basins, fisheries were based on large, long-distance migratory species (e.g. large catfishes and characids) with high commercial and sporting value. After reservoir formation, the stocks of these species decreased and were replaced by smaller and less valuable species (Petrere et al., 2002; Okada et al., 2005; Hoeinghaus et al., 2009).

Commercial fisheries practised in reservoirs contrast to those conducted in lotic stretches of the basin. Fishers do not have the same traditional characteristics. Most fishers in this case have been fishing for $<30$ years and previously worked in other economic activities (Agostinho et al., 2008). In addition, small landowners, who had part of their land inundated by reservoirs, now produce insufficient income based on agriculture and turn to this type of fishing to supplement their family income.

A recurrent phenomenon observed in the region is the massive arrival of workers who participated in the construction of dams into the fisheries due to the lack of job opportunities. These workers are attracted by the high yields of the first years after impoundment (heterotrophic phase). When the trophic depletion of reservoirs begins, catches are drastically reduced. To overcome this problem, fishers increase effort, which results in the collapse of stocks and various other issues, especially poverty (Agostinho et al., 2007a). 
In spite of the large amounts of surface fresh water (Amazon and Paraná-La Plata Basins) and aquifers on a continental scale, some regions of South America have a semi-arid to arid climate (Brazilian north-east, Patagonia and Chile). In these regions river dams are mostly for providing water supply for urban and rural populations, since the available volumes are not enough for power generation (exception is the São Francisco River). The best example, although not the only one, is the Brazilian north-east. The semi-arid climate and the extremely high population densities have resulted in the need for a number of small dams to store water from the short and low-flow coastal rivers that drain to the equatorial Atlantic Ocean. The operating procedures for these dams and the reservoirs are also a concern for fish conservation in South America. The little freshwater supply that used to arrive at the coastal areas is now almost totally controlled. At the same time, sediments and nutrient inputs have been severely modified. Coastal habitats such as mangroves and beaches are already suffering a lack of sediment supply, marine intrusion and other forms of habitat modifications. One of the most serious concerns is the release of water via bottom spillways. This water is usually loaded with organic matter and therefore has a powerful dissolved oxygen demand and carries other pollutants. All these factors are only aggravated by the nature of the flooded land, which has once been agricultural fields (sugar and alcohol-cane) and that water temperatures in the region are normally $>25^{\circ} \mathrm{C}$.

\section{PERSPECTIVES FOR CONSERVATION}

Actions taken to manage reservoir effects on the ichthyofauna and to help conserve fishery resources and yields are restricted to stocking programmes, construction of fish passages and some fishery controls. Despite some local successes, these efforts have not been efficient basin-wide, with regard to either conservation or improving the sustainability of fisheries (Agostinho et al., 2004, 2007b). Reasons for failure include: (1) insufficient knowledge of the managed systems, (2); lack of clear objectives, (3) use of inadequate (adapted from other different world regions) management protocols and (4) lack of monitoring.

\section{CURRENT STATUS OF SELECTED SOUTH AMERICAN ESTUARINE AND MARINE ECOSYSTEMS}

\section{ROLE OF RIVER FLOW IN COASTAL FISH DISTRIBUTION PATTERNS}

The south-west Atlantic coastal system (SWACS; Fig. 1), including coastal lagoons (Mar Chiquita, Rocha), estuaries (La Plata, Rincon) and bays (Samborombón, Anegada), provides critical habitats for many commercial and recreational species (main feeding, mating, spawning and nursery grounds) and are characterized by a great variability of oceanographic conditions. SWACS also support human activities (e.g. fishing and environmental modifications).

Monitoring and knowledge of the effects of small and large-scale patterns in abiotic conditions are necessary for a more complete understanding of fish and fisheries dynamics and therefore, effective management. The linkage between the ecosystem 
and management practice is provide by solid ecological knowledge and understanding of the dynamics of the source and the ecosystem in which it operates.

The physical dynamics of SWACS, a broad and shallow water $(<50 \mathrm{~m}$ deep) continental shelf of $c .108 \mathrm{~km}^{2}$, is governed by the atmospheric temperate thermal cycle, local water inputs, advection of modified subantarctic shelf water (from the south) and shelf subtropical water (from the north) and prevailing winds (Guerrero \& Piola, 1997; Lucas et al., 2005). Temperature, which controls seasonal stratification over the continental shelf, displays a pronounced seasonal cycle, typical of temperate areas, and reaches a maximum in summer $\left(18-23^{\circ} \mathrm{C}\right)$ and a minimum in winter $\left(9-11^{\circ} \mathrm{C}\right)$. Its horizontal distribution is closely coupled with the underlying bathymetry, as its thermal mass is directly related to thickness of the water column (Lucas et al., 2005). The main local water inputs generate two main estuarine systems, La Plata River and El Rincón. The La Plata River has an extensive shallow coastal-plain microtidal estuary. The combined discharge of the Negro and Colorado Rivers generates the El Rincón estuarine system, a shallow funnel-shaped coastal area, oriented roughly north-west and south-east. The El Rincón system interacts, at its external boundary, with salty (33.7-34.2) waters coming from San Matías Gulf, a semi-closed coastal embayment with depths greater than the adjacent shelf (60-200 m) (Lucas et al., 2005). On a seasonal scale, the prevailing winds and river are the main forcing mechanism for the extension and contraction of the estuarine system and their interaction with the surrounding shelf water (subantarctic and subtropical water) within SWACS (Palma et al., 2004; Simionato et al., 2004). During autumn to winter, under a near-balance of onshore and offshore winds, the slope of the La Plata River discharge induces a north-north-east drift of coastal waters along the Uruguayan and southern Brazilian coast, and the high salinity water from El Rincón shows its maximum northward extension (Lucas et al., 2005), forcing a southern intrusion of cold and salty shelf waters into the estuary along the coast (Guerrero \& Piola, 1997). During spring-summer, the coastal system is under the influence of onshore winds and Ekman drift forces waters southward, generating a freshwater tongue along the Argentine coast, occasionally observed southward of San Antonio Cape (Guerrero \& Piola, 1997). During this period, the El Rincón basin is dominated by lower salinity waters due to retraction of the high salinity flow from the San Matías Gulf and a peak in the freshwater discharge of the Negro River (Lucas et al., 2005). This condition, in combination with the extension of La Plata River waters along the Argentine coast, generates an intrusion into the estuary of salty shelf water along the Uruguayan coast (Guerrero \& Piola, 1997).

\section{ENVIRONMENTAL INFLUENCE ON DISTRIBUTION OF FISHES}

Seasonal and annual variability in the SWACS oceanographic conditions influence various fish biological behaviours (migration, spawning, mating and bottom fidelity) and influence the seasonal and interannual coastal habitat use that determine fish catchability and susceptibility. The salinity and temperature are related to factors that influence ontogenetic changes in fish habitat associations (Jaureguizar et al., 2003a, 2008; Cortés et al., 2008). Fish assemblage habitat associations (Díaz de Astarloa et al., 1999; Jaureguizar et al., 2003b, 2006a, b; Lorenzo Pereiro, 2007), and their 
spatial distribution as a consequence of changing river flow or winds affects species availability to artisanal fisheries along the coast (Lagos, 2001; Nagy et al., 2006).

On a large spatial scale, the strong physical environment gradient along SWACS (Fig. 1) creates a gradual change in the fish composition from fresh and shallow $(3.5 \mathrm{~m})$ to marine and deeper waters $(60 \mathrm{~m})$ that define the riverine, estuarine and coastal shelf fish assemblages (Anganuzzi, 1983; Jaureguizar et al., 2004; Lorenzo Pereiro, 2007). The riverine fish assemblages occupy the inner part of La Plata River, characterized by fresh water (salinity $0.08 \pm 0.02)$ and shallow depth $(7.88 \pm$ $1.53 \mathrm{~m}$ ). Its ichthyofauna form part of the Paranoplatense fish community and show a high affinity to the Paraná and Uruguay Rivers basins (Cousseau, 1985). It is mainly dominated by freshwater [Paraloricaria vetula (Valenciennes), Pimelodus albicans (Valenciennes), L. obtusidens, Pterodoras granulosus (Valenciennes), C. carpio, L. pati and P. valenciennis] and anadromous species [Genidens barbus (Lacépède) and L. grossidens] (Jaureguizar et al., 2004). The anadromous species, G. barbus during spring and early summer, and L. grossidens during the autumn and early winter, penetrate into the La Plata River and its basin to spawn (Fuster de Plaza \& Boschi, 1961; Menni, 2004). The estuarine fish assemblage occupies the mixohaline waters of the La Plata Estuary, and its ichthyofauna is dominated by euryhaline species of marine origin. The species composition shows a gradient to the mouth where estuarine resident species predominate [Micropogonias furnieri (Desmarest), Anchoa marinii Hildebrand, Brevoortia aurea (Spix \& Agassiz), Percophis Brasiliensis Quoy \& Gaimard, Macrodon ancylodon (Bloch \& Schneider) and Paralichthys orbignyanus (Valenciennes)] and, to a lesser degree, occasional freshwater species (P. albicans, $P$. valenciennis and L. pati), marine species, either stragglers [Cynoscion guatucupa (Cuvier), Conger orbignyanus Valenciennes and Paralichthys patagonicus Jordan] or migrants [Prionotus punctatus (Bloch), Sympterygia bonapartii Müller \& Henle and Menticirrhus americanus (L.)], and estuarine migrants (Mugil spp.) (Anganuzzi, 1983; Prenski \& Sánchez, 1988; Lasta et al., 1998; Díaz de Astarloa et al., 1999; Jaureguizar et al., 2006b). The estuarine resident species use Samborombón Bay as the main nursery area (Lasta, 1995). The shelf-fish assemblage occupies the salty waters (mean \pm S.D. $31.61 \pm 1.45$ ) from the coast to $50 \mathrm{~m}$ depth, and in the north SWACS region it extends outside of the estuarine ecosystem. The fish community is dominated by marine species [Atlantoraja castelnaui (Miranda Ribeiro), C. orbignyanus, C. guatucupa, Discopyge tschudii Heckel, Mustelus schmitti Springer, Squatina guggenheim Marini, Sympterygia acuta Garman, S. bonapartii, Trichiurus lepturus L., Trachurus lathami Nichols, P. patagonicus, Prionotus nudigula Ginsburg, P. brasiliensis, Urophycis brasiliensis (Kaup) (Anganuzzi, 1983; Prenski \& Sánchez, 1988; Lasta et al., 1998; Díaz de Astarloa et al, 1999; García et al., 2003; Jaureguizar et al., 2004, 2006b)]. Some species perform seasonal migrations within the shelf ecosystem as a result of water-mass dynamics (e.g. T. lepturus and D. tschudii) or reproductive movements (e.g. M. furnieri, M. schmitti and C. guatucupa) causing seasonal changes in the shelf and estuarine fish composition (Jaureguizar et al., 2004).

The riverine-estuarine border is near the location where the halocline intersects the bottom (Fig. 2), and corresponds to the bottom salinity front (Guerrero \& Piola, 1997). This represents the boundary for intrusions of freshwater species into the estuary (L. pati, P. valenciennis, L. obtusidens, P. lineatus and species of Loricariidae) (Jaureguizar et al., 2003b, 2004). The border zone between the estuarine and shelf 


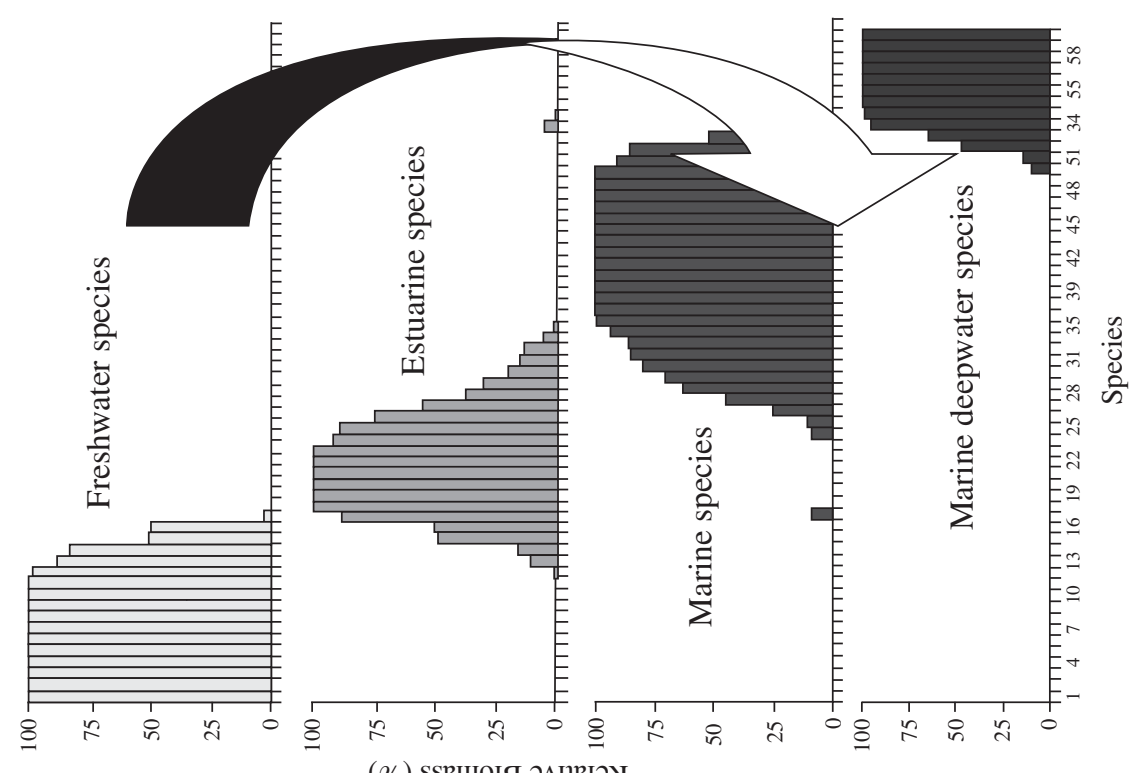

อ

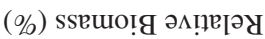
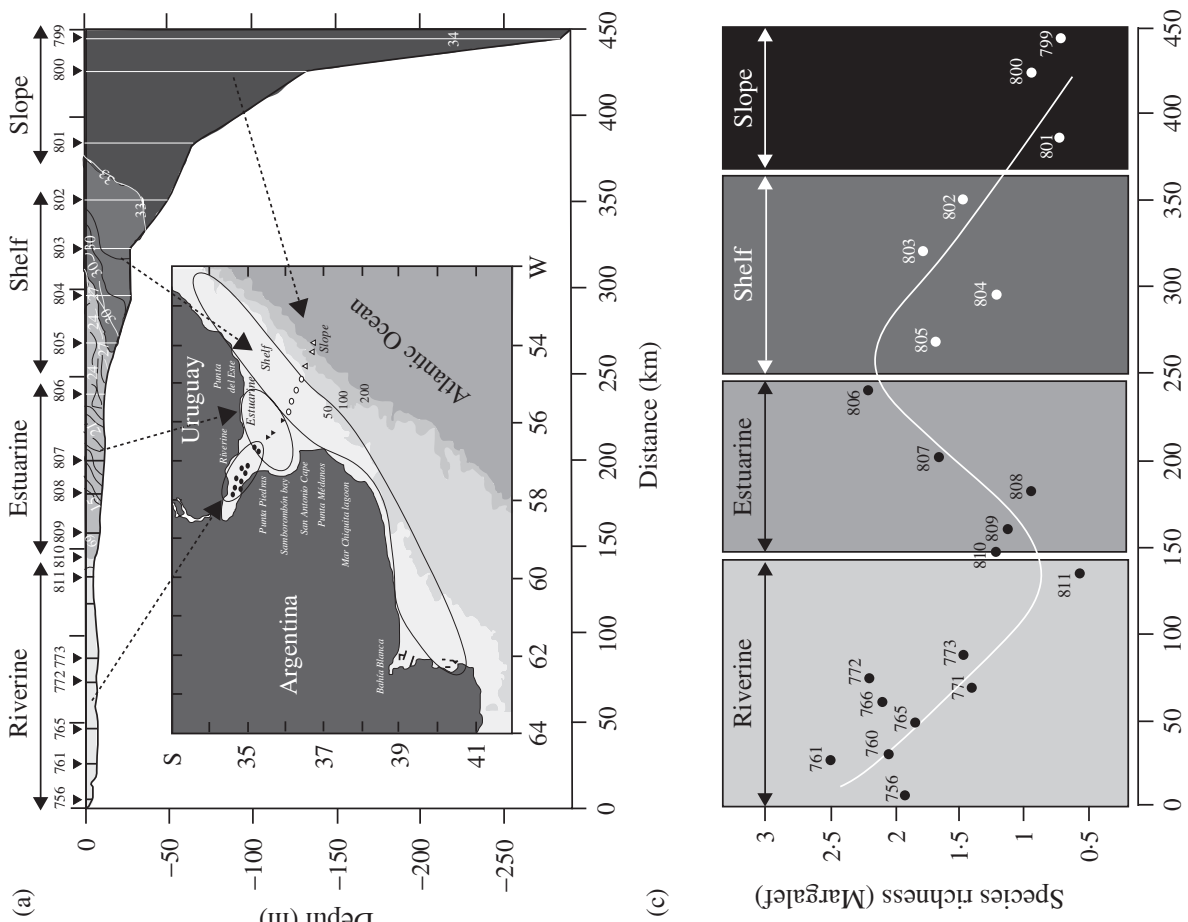

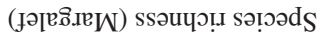


assemblages (Fig. 2) coincides with the location of the maximum horizontal gradient of surface salinity indicating the boundary between the estuary and the continental coastal waters (Jaureguizar et al., 2007). The persistent salinity vertical structure in the estuarine ecosystem shows the presence of a shelf water intrusion along the bottom, which allows the incursion of marine species towards the head of the estuary (Jaureguizar et al., 2003b). This zone is the limit for the presence in the estuary of marine species such as Mullus argentinus Hubbs \& Marini, Pagrus pagrus (L.), Merluccius hubbsi Marini and T. lathami. Both border zones coincide with minimum (among riverine and estuarine fish assemblages) and maximum (among the estuarine and coastal shelf fish assemblages) of species richness (Margalef index; Ludwig \& Reynolds, 1998), respectively (Fig. 2).

The north-south, as well as the top-down estuary movements of the fish assemblages reflect the combined influence of the seasonal distribution of shelf water masses along the SWACS and the discharge pattern of the La Plata River (Jaureguizar et al., 2004). During autumn to winter the environmental conditions, when cold and high salinity waters cover a large area of the SWACS, allow for a wider distribution of marine species associated with shelf water (D. tschudii and $P$. nudigula), even forcing an intrusion into the south of the La Plata River estuary (Jaureguizar et al., 2007). Discopyge tschudii is a cold water species and considered a Magellanic form (Menni \& Gosztonyi, 1982). On the other hand, spring and summer environmental conditions generate a lesser southbound intrusion in the La Plata River, but force an intrusion of marine species (T. lepturus) along the Uruguayan coast. In addition, interannual variations in the discharge of the La Plata River and the synoptic winds can explain the interannual variations in the geographical extension within each season. During spring, the influence of high freshwater discharge of the La Plata River during El Niño events (e.g. 1983 and 1998), associated with high precipitation (Robertson \& Mechoso, 1998; Camilloni \& Barros, 2000), produces a movement of the estuarine fish assemblage to the coastal shelf. On the other hand, during La Niña events, decreases of freshwater discharge of the La Plata River estuary induce movement of the estuarine fish assemblage upstream (e.g.

FIG. 2. (a) Location of the fish assemblage areas on the distribution of salinity, (b) relative biomass (\%) of the species by fish assemblage area (García et al., 2003) and (c) the species richness variation along environment gradient. (1) Ageneiosus. valenciennesi, (2) Brochiloricaria chauliodon, (3) Cyprinus carpio, (4) Hypostomus laplatae, (5) Leporinus obtusidens, (6) Pachyurus bonariensis, (7) Paraloricaria vetula, (8) Pimelodus maculatus, (9) Prochilodus lineatus, (10) Pterodoras. granulosus, (11) Genidens barbus, (12) Rhinodoras dorbignyi, (13) Pimelodus albicans, (14) Luciopimelodus pati, (15) Parapimelodus valenciennis, (16) Lycengraulis grossidens, (17) Micropogonias furnieri, (18) Anchoa marinii, (19) Brevoortia aurea, (20) Conger orbignyanus, (21) Cynoscion guatucupa, (22) Percophis brasiliensis, (23) Macrodon ancylodon, (24) Prionotus punctatus, (25) Parona signata, (26) Sympterygia bonapartii, (27) Paralichthys patagonicus, (28) Myliobatis goodei, (29) Trichiurus lepturus, (30) Mustelus schmitti, (31) Rioraja agassizi, (32) Squatina guggenheim, (33) Stromateus brasiliensis, (34) Trachurus lathami, (35) Acanthistius brasilianus, (36) Atlantoraja castelnaui, (37) Dules auriga, (38) Galeorhinus galeus, (39) Mullus argentinae, (40) Myliobatis goodei, (41) Pagrus pagrus, (42) Percophis. brasiliensis, (43) Prionotus nudigula, (44) Pseudopercis semifasciata, (45) Squalus megalops, (46) Thyrsitops lepidopodea, (47) Zapterys brevirostris, (48) Discopyge tschudii, (49) Xystreurys rasile, (50) Nemadactylus bergi, (51) Merluccius hubbsi, (52) Urophysis brasiliensis, (54) Coelorhynchus marinii, (55) Genypterus blacodes, (56) Helicolenus dactylopterus lahillei, (57) Macruronus magellanicus, (58) Patagonotothem ramsayi, (59) Squalus acanthias and (60) Squalus mitsukurii. 
1994 and 1999) (Jaureguizar et al., 2006b). Although the fish assemblages show few geographical variations $(<100 \mathrm{~km})$, affecting the inner coastal fisheries of the La Plata Estuary (Pajas Blancas, Uruguay) and its adjacent marine waters (San Antonio Cape, Argentina) (Lagos, 2001; Nagy et al., 2006), a relative persistence in their resident species composition and diversity can be observed (Jaureguizar et al., 2006b; Lorenzo Pereiro, 2007).

\section{SOUTH-WESTERN ATLANTIC ESTUARINE AND MARINE ECOS Y STEMS}

\section{Distribution pattern of fish in mangrove estuaries}

A mangrove estuary results from the interplay between marine and fresh water influences that dominate every aspect of the system as both external drivers and ecological stressors. The controlling marine influence is the semi-diurnal tidal rise and, at the other end, the seasonal fluctuation of freshwater river flow. Fish assemblages can be described in relation to biomass, density, and number of species, and the seasonal fluctuation of environmental variables (salinity, water temperature and dissolved oxygen). These variables change in the estuary main channel and intertidal mangrove forest, at both high and low tide.

The New World mangrove ecosystems cover an estimated 4.3 million ha representing $28 \%$ of the world's mangroves and are spread along Pacific and Atlantic coastlines. Nearly $73 \%$ of the total mangrove area of the American continental coastline occurs in the south-western Atlantic Ocean and Caribbean (Lacerda et al., 2002). In the western Atlantic Ocean coastal mangroves stretch from Bermuda ( $32^{\circ}$ $\left.20^{\prime} \mathrm{N}\right)$ to Laguna, Santa Catarina, in southern Brazil $\left(28^{\circ} 30^{\prime} \mathrm{S}\right)$. The eastern limit is Fernando de Noronha Islands, Brazil ( $\left.3^{\circ} 50^{\prime} \mathrm{S} ; 32^{\circ} 34^{\prime} \mathrm{W}\right)$. On the south-western Atlantic Ocean and Caribbean mangrove coasts, the diversity is low with only five genera and nine species of mangrove trees (Lacerda et al., 2002). The most abundant species are Rhizophora mangle, Laguncularia racemosa and Avicennia germinans.

The mangrove forest along the northern coast of South America is not flooded during low tide (tidal range: 5-7 m). Nevertheless, many fish species remain in the mangrove forest during this time. Tidal behaviour strategies are described for fish species that linger in the mangrove forest during low tide. In this habitat, a total density of 2.8 individuals $\mathrm{m}^{-2}$ and a total biomass of $17.4 \mathrm{~g} \mathrm{~m}^{-2}$ are recorded at low tide. Myrophis punctatus Lütken is the most important species in number (1.7 individuals $\mathrm{m}^{-2}$ ) and mass $\left(12.7 \mathrm{~g} \mathrm{~m}^{-2}\right)$. Spatial and temporal interactions were observed for densities and biomass for the dominant species [M. punctatus, Poecilia spp. and Gobionellus smaragdus (Valenciennes)] (Barletta et al., 2000).

Migration trends are inferred from the results of the seasonal fluctuations of density and biomass of the most important species in the mangrove tidal creeks and main channel of the estuary (Barletta-Bergan et al., 2002a, b; Barletta et al., 2003, 2005). In the Caeté Estuary (eastern Amazon, tropical and humid), seasonal salinity fluctuation is the main factor that structures the fish assemblages in the entire estuarine system (Barletta et al., 2003, 2005). In this estuary, the salinity shows a seasonal trend. At the beginning of the rainy season in all areas the salinity values decrease. After this period the rainfall decreases and salinity rises again. Independent from season, the upper estuary shows the lowest salinity values and the lower the highest 
ones. Water temperature, except in the lower estuary, and dissolved oxygen show the same seasonal trends as salinity (Barletta et al., 2003, 2005).

The estuary supports a resident fish community that is functionally important as an intermediate trophic level for many consumers. The production and seasonal occurrence of fishes appear to vary with salinity, hydrology and nutrient status in the estuary, all of which are controlled by both freshwater flow and tidal sea level rise. Many species are adapted to these salinity fluctuations and are resident within the estuarine habitats. Other species stay in the estuary only during a certain period of their life and when the conditions are appropriate. Estuaries are frequently referred to as nursery areas for both fishes and invertebrates (Beck et al., 2001). Ichthyoplankton can originate either from within the estuary or from adjacent marine and freshwater environments (Barletta-Bergan et al., 2002a). Juveniles use the estuary as a feeding ground and refuge (Krumme et al., 2005). Marine species move to coastal shallow waters before reaching maturity, where they contribute to the coastal fisheries yield (Barletta et al., 1998, 2003). The structure and seasonal dynamics of the fish larvae and juvenile fish communities show clearly the importance of the main channel (Barletta-Bergan et al., 2002a, Barletta et al., 2005) and mangrove forest (Barletta-Bergan et al., 2002b, Barletta et al., 2003) of the estuary as a fish nursery habitat. This estuary is no exception; Embley Estuary (northern Australia) habitats have the same function when compared with the Caete Estuary (Barletta \& Blaber, 2007). The intertidal mangrove areas are also considered essential nursery grounds for fish fauna often including commercially important species (Morton, 1990; Laegdsgaard \& Johnson, 1995; Barletta et al., 2003). The north Brazilian coast (tropical and humid) houses the largest continuous mangrove estuarine belt in the world and constitutes $56.6 \%$ of the mangroves in South America $\left(7591 \mathrm{~km}^{2}\right)$ (Souza Filho, 2005). Although large tracts of this area currently remain undisturbed, uncontrolled population growth and inefficient management of the natural resources, combined with lack of governance among environmental institutions, poses a threat to the conservation of this unique mangrove ecosystem. According to Barletta \& Costa (2009) and Costa et al. 2009 along the north-east Brazilian coast (e.g. Goiana River estuary, tropical and semi-arid) the deforestation of the Atlantic rain forest, soil erosion, river and estuaries aggradation, loss of aquatic habitat by land reclamation, eutrophication ( $\mathrm{N}, \mathrm{P}$ and oxygen-consuming effluents) chemical contamination (depending on the phase of the sugar and alcohol production) and social stress are the consequence of sugar and alcohol-cane plantations, milling, alcohol and sugar production. The authors also highlighted that aquaculture farms are present in the middle and lower estuary. Prawns Litopenaeus vannamei are the preferred stock, but tilapia Oreochromis urolepis hornorum (Norman) are also viable. The choice of investment depends heavily on market demands and government initiatives, but never on social and ecological needs. Both types of agro-industry reclaimed extensive areas of the mangrove forest and pump water from the estuary and discard effluents to the main channel.

\section{The intertidal mangrove fish fauna}

South of the mouth of the Amazon River, more than 30 estuaries fringe $c .650 \mathrm{~km}$ of mangrove-dominated coastline. So far, published information on this mangrove creek fish fauna is available only from three mangrove systems: (1) the Curuçá Estuary located at the eastern tip of the mouth of the southern channel of the Amazon 
Delta (Pará River), (2) the Caeté Estuary near Bragança, Pará (200 km from the Amazon mouth) and (3) the estuaries on the São Luis and Caranguejo Islands located in São Marcos Bay, Maranhão (550 km from the Amazon mouth) (Fig. 1). Over half of the studies to assess spatial and temporal variation in mangrove intertidal fish assemblages have used fixed sampling designs on a small scale $(<2 \mathrm{~km}$ between creeks sampled). In the Caeté Estuary (Fig.1), Barletta-Bergan et al. (2002b) and Barletta et al. (2003) studied the annual cycle of fishes (larval, juveniles and adult stages) in three first order mangrove creeks. The smallest creek had significant larval fish densities (Barletta-Bergan et al., 2002b). In the same area, Krumme et al. (2004) have investigated the tidal and diel changes in the nektonic fauna composition in two second-order mangrove creeks. There were no significant spatial differences. On the São Luis Island, Batista \& Rêgo (1996) pooled the catches from four first-order creeks (1.3 km maximum distance between creeks sampled) to study an annual cycle in fish fauna changes; Castro (2001) compared the annual cycle of the fish fauna in three first-order creeks (1.5 km maximum distance between creeks sampled), however, catch data were not standardized to biomass or density.

Only three studies focused on a medium spatial scale analysis ( 2 to $20 \mathrm{~km}$ between creeks sampled) to elucidate possible inter-creek variability in fish habitat use according to a standardized methodological protocol. Barletta et al. (2000) described the spatial and temporal variation in fish fauna assemblages that linger in the mangrove forest of the Caeté Estuary during low tide. Fourteen fish species were caught using an ichthyotoxic plant in six areas along the estuary. The three most dominant species showed spatial-temporal variations in density in accordance with salinity variations in the estuary. In addition, the high species richness in innermost areas was explained by the occurrence of both freshwater and estuarine fish species in these areas.

In the Curuçá Estuary, Giarrizzo \& Krumme (2007) studied the annual cycle of fishes in four intertidal mangrove creeks. In these creeks, temporal patterns in fish fauna composition occurred cyclically according to seasonal changes in salinity, but overall density and biomass did not differ throughout the year. This would imply an optimized use of the intertidal creek habitat over time by the fishes since similar numbers and standing stock were apparently maintained all year round as observed by Barletta et al. (2003). Additionally, biomass and density of juvenile fishes were significantly different in the two middle estuarine creeks than in the two inner estuarine creeks throughout the year suggesting that they are, per se, important juvenile fish habitats. The results showed that the nursery value of mangrove creeks varied on a scale of $4 \mathrm{~km}$ suggesting high habitat diversity, being mainly attributable to relative estuarine location and landscape features. These findings were supported by Sarpedonti et al. (2008) studying the same estuarine system, where the ichthyoplankton of two mangrove creeks, located $8 \mathrm{~km}$ apart from a homogeneous salinity zone, showed significant spatial differences between the body size of larvae. Based on these observations, important factors can be responsible for the heterogeneity among the north Brazilian estuaries (eastern Amazon), including proximity to the plume of the Amazon River, freshwater and nutrient input $v$. marine influence, tidal range, and geomorphology of the estuary and non-estuarine embayment. Comparisons of the intertidal fish fauna among estuaries and non-estuarine embayments along the northern Brazilian mangrove coastline revealed a significant heterogeneity in the species composition, functional and ecological guilds (Giarrizzo \& Krumme, 2008; Viana et al., 2010). Independent of this fish assemblage variability, it is clear that 
seasonal variations in salinity are the most important variable that influence the fish assemblage composition and structure in northern South American estuarine habitats (Cervigón, 1985; Lowe-McConnell, 1987; Morais \& Morais, 1994; Barletta et al., 2000, 2003, 2005; Barletta-Bergan et al., 2002a, b).

\section{Fish and fisheries in the mangrove forest}

In the northern Brazilian estuarine mangrove belt, complex networks of branching intertidal creeks are flooded twice daily (4-7.5 m tidal range). Many fish species use the intertidal creeks for tidal migrations between mangrove habitats and the sub-tidal areas. The artisanal fishers take advantage of these tidal fish movements, setting passive fishing gear in the intertidal creeks. Common large intertidal fish weirs (currais) are placed in the mudflats and sandbanks, while temporary net barriers (block-nets) are used in mangrove creeks (Barletta et al., 1998). The increase in use of intertidal fish weirs and block-nets with small mesh size $(<2 \mathrm{~cm})$ sometimes associated with an ichthyotoxic plant can have adverse effects on the environment and fish recruitment due to their non-selectivity.

In order to protect natural resources, including fishes and fish habitats, the Brazilian government established the National System of Conservation Units (SNUC, 2000), responsible for planning and implementing the National Policy for Protected Areas administrated by Ministry of the Environment. Yet, although several conservation units (CU) have been created, the SNUC has not been able to fulfil its conservation objectives. The main obstacles to an effective implementation of SNUC have been: (1) insufficient public resources allocated to coastal management, (2) limited participation by the local populations in decision-making regarding natural resources management and conservation, (3) political instability at the local level, (4) lack of monitoring from the environmental authorities and (5) lack of ecological and biological data.

\section{Research and management implications}

Understanding the variations in fish fauna at different spatial and temporal scales can provide valuable insights for management and conservation. The results from the present review on the intertidal mangrove fish fauna in north Brazil suggests that an estuarine system, even though homogeneous in salinity, as well as in the other environmental variables, may have different nursery values. The geographical comparison of the intertidal fish fauna between three estuaries along the continuous mangrove belt south of the Amazon River mouth has shown that the assemblage is heterogeneous in terms of species composition and contribution of functional and ecological guilds. Although these findings were determined from only four previous studies, the comparisons provide enough data to recognize the absolute necessity for conservation in the region. The high spatial heterogeneity and the different fish fauna assemblages necessitate a habitat classification of mangrove landscape features employing readily obtainable quantitative data for geophysical and oceanographic characteristics. This categorization could provide data that correlate fish assemblages or key species to specific estuaries or coastal sectors. This would offer the necessary aid to regional management systems, and provide a framework for research, monitoring and conservation of the mangrove ecosystem. 


\section{Riverine, estuarine and marine connections}

Seasonal fluctuations of the environmental variables (salinity, dissolved oxygen and water temperature) structure the fish assemblages in the main channel of the estuary (Barletta et al., 2005, 2008; Dantas et al., 2010). Studies of estuarine fish assemblages show that they undergo large seasonal fluctuations in biomass and density. The estuarine dependent species are ordered along a large-scale spatial gradient during the early and principally the late dry season, when relatively stable hydrological conditions create a well-defined salinity gradient in the estuary (Barletta et al., 2005). On the other hand, during the late rainy season, freshwater runoff increases, salinity declines and the estuary becomes suitable for freshwater fishes (P. blochii, B. vaillanti, Hypostomus plecostomus (L.) and Loricaria sp.) and brackish-water fish species [Pseudauchenipterus nodosus (Bloch)] (Barletta et al., 2005). According to Barletta \& Blaber (2007), these freshwater species (Siluriiformes) characteristic of the upper Caeté Estuary have no equivalent functional guilds in the Embley Estuary (Indo-West Pacific, North Australia). Representatives of this order and the Characiformes, Gymotiformes and Perciformes were able to colonize Asian, African and South American waters before these continents were separated. Aside from two catfish families (Ariidae and Plotosidae) that became secondarily adapted to salt water, Ostariophysans have not been able to reach Madagascar, the West Indies, New Zealand and Australia. This suggests that those land masses have not been connected to any of the larger continents since the upper Jurassic (Briggs, 1996). This also explains why, despite seemingly suitable habitats and hydrological conditions, there are no freshwater ostariophysan species in the Embley Estuary.

Not only salinity but also turbidity is indicated as an important factor associated with larval fish abundance (Cyrus \& Blaber, 1987a, $b$; Whitfield, 1994a, $b$; BarlettaBergan et al., 2002a). Melville-Smith et al. (1981) and Barletta-Bergan et al. (2002a) suggested that high abundance in most upstream sections of the estuary may reduce the chances of larvae being flushed out to less productive, inhospitable, offshore areas where they subsequently die. Additionally, increased organic matter and turbidity in the upper reaches of the estuary might also provide shelter from predation for larval fish assemblages (Barletta-Bergan et al., 2002a). The authors also concluded that the species number was greatest in the upper estuary, a feature which reflects the penetration of a few freshwater and marine species, and the presence of the estuarine ones in this area of the estuary. Young of the year (YOY) and adult fishes are captured more in the upper estuary. When the salinity values rise in the estuary, during the early and late dry season, these species move upstream towards the upper estuary for spawning and shelter for YOY. During the end of the rainy season, however, a strong reduction of salinity values in the entire ecosystem is observed, independent of turbidity and most of the fishes move downstream to inshore areas (Barletta et al., 2005).

Seasonal fluctuation in density and biomass of catfishes [Cathorops spixii (Agassiz), Cathorops agassizii (Eigenmann \& Eigenmann), Sciades herzbergii (Bloch), Amphiarius phrygiatus (Valenciennes), Aspistor parkeri (Traill), Sciades couma (Valenciennes), Aspistor luniscutis (Valenciennes), Sciades proops (Valenciennes)], in the Goiana Estuary (tropical semi-arid of north-east Brazil) is positively correlated not only with salinity but also with dissolved oxygen during the rainy season (Dantas et al., 2010) (Fig. 1). In this estuary, located at the eastern Amazon (tropic humid region) (Barletta et al., 2005), salinity is also an important environmental variable 
which influences the fish assemblage distribution pattern in the different reaches. The Paranaguá Estuary (tropical to subtropical transition zone, south Brazil), however, seems to be an exception to this model, since the middle and lower estuary have stable salinity values even towards the late rainy season, and the most abundant estuarine species remain in these areas of the estuary during this period (Barletta et al., 2008) (Fig. 1). This suggests that the combinations of geomorphology of the estuary and river flow basin drainage are also factors influencing the fish assemblage' distribution in the ecocline of an estuarine ecosystem.

The importance of estuarine ecosystems as spawning, nursery and protection areas not only for fishes but also for invertebrates is clear. For that reason, management and conservation of these systems should take into account the life cycle of the species which utilize these ecosystems. Moreover, the lives of traditional populations depend upon minimum environmental quality in estuaries from where they access resources for subsistence and artisanal fisheries (Barletta \& Costa, 2009; Costa et al. 2009).

Estuaries have historically been strategic for economic growth because they are sheltered waters and have therefore suffered significant anthropogenic pressures (M. Barletta, M.F. Costa, A.C.R. Couto, M.F.M. Corrêa \& U. Saint-Paul, unpubl. data). Port construction and operations are usually state-based or state-controlled activities; however, these operations are under the highly competitive market rules. Land reclamation, state building, ports and terminals, industrial plants and dredging of waterways are all part of a non-sustainable economic model which, so far, has failed to take into consideration any ecological limits of the estuarine environment (Kennish, 1998). One of the most significant, and often neglected, ecological pressures on these systems is the capital and maintenance dredging of the shipping channel which provides access to port and terminal facilities (Kennish, 1992). Taking into account this information, Barletta et al. (M. Barletta, M.F. Costa, A.C.R. Couto, M.F.M. Corrêa \& U. Saint-Paul, unpubl. data) have described the effects of dredging of the main channel of the Paranaguá Estuary comparing the demersal fish communities before, during and after dredging. Moreover, comparisons with the same months and seasonal period of the year before dredging (Barletta et al., 2008) were also made in order to quantify possible seasonal differences between years on the fish assemblages. The authors concluded that, in the Paranaguá Estuary, during the year of the dredging process, significant differences were observed for a number of species, Genidens genidens (Cuvier) and C. spixii (density and biomass) and A. luniscutis. Most of these species showed highest values of density and biomass in the main channel of the estuary during the dredging process. Genidens barbus, showed the same tendencies, but the highest densities and biomass were detected in the adjacent area where the dredging operation takes place. On the other hand, Cynoscion leiarchus (Cuvier) and Menticirrhus americanus (L.) showed the lowest values of density and biomass during the dredging, and after the dredging were not captured at all. These results strongly suggest that the dredging had an influence on the fish assemblage distribution in the estuary (M. Barletta, M.F. Costa, A.C.R. Couto, M.F.M. Corrêa \& U. Saint-Paul, unpubl. data).

\section{PATOS LAGOON BASIN}

The Patos Lagoon basin is a large $\left(201626 \mathrm{~km}^{2}\right)$ heterogeneous drainage system shared between Brazil and Uruguay (Fig. 1). The lagoon is $250 \mathrm{~km}$ long and $60 \mathrm{~km}$ 
wide, covering an area of $10360 \mathrm{~km}^{2}$. The middle and upper portions of Patos Lagoon is predominantly fresh to oligohaline (Odebrecht et al., 2005). The estuarine area is restricted to, on average, only $10 \%$ of the area at the lower portion, although the upper limit of saline waters migrates seasonally and year to year depending on hydrological balances (Möller et al., 2001).

The Guaíba River is the major hydrographic feature of the Patos Lagoon system, with a length of $710 \mathrm{~km}$ in the main channel (Jacuí River), a catchment area of $87700 \mathrm{~km}^{2}$ and an average discharge of $c .1500 \mathrm{~m}^{3} \mathrm{~s}^{-1}$. In the middle west of the Patos Lagoon, there is the Camaquã Basin, with a catchment area of $24000 \mathrm{~km}^{2}$.

The Mirim Lagoon is located between Brazil and Uruguay, with an average area of $6000 \mathrm{~km}^{2}$ (Bracco et al., 2005). During periods of high waters and intense rainfall, Mirim Lagoon and the adjacent wetland system drains into Patos Lagoon. In 1977, a dam was built on this channel to prevent the entrance of saline waters from Patos Lagoon into the Mirim Lagoon (Burns et al., 2006), allowing a constant supply of fresh water for irrigation of rice fields along the lagoon's margins.

\section{Fish assemblage diversity, threats and distribution}

The Patos Lagoon drainage area has 121 limnetic fish species (Grosser \& Hahn, 1981; Malabarba, 1989; Reis et al., 2003b; Becker et al., 2007). In the estuary, fish diversity increases to c. 150 species (Chao et al., 1985; Vieira \& Castello, 1997; García \& Vieira, 2001).

Threats to fish populations in the Patos Lagoon system are diverse and spread over the entire basin. This basin suffers pressure from almost 7 million inhabitants, concentrated in small to large cities, most of them living with untreated domestic effluent. Economic activities are diverse, from intensive agriculture of soybean, corn and wheat in well-drained areas to rice in the wetlands. There is also intensive chicken and pork farming and extensive cattle ranching. Industrial production is widespread, including chemical, petrochemical, metal-mechanic, cellulose and leather factories. Mining includes coal, zinc, copper, lead and sand.

In 2006 and 2007, several field trips were made throughout the Guaíba Basin, trying to map the distribution of migratory fishes [Salminus brasiliensis, P. lineatus, L. obtusidens and Pimelodus pintado Azpelicueta, Lundberg \& Loureiro] by means of interviews with old residents and fishers (Alves \& Fontoura, 2009). The objective of this study was to identify the effect of hydroelectric power generation plants (dams) as obstacles to migratory fishes. According to the old residents of the upper Jacuí and Taquarí Basins, the causes of the reduction of fish populations were related to overfishing. Nylon gillnets started to be used regularly and without control $c$. 30-40 years ago. Residents also reported massive mortality events associated with pesticides and industrial untreated effluents. Against this background, direct effects of river damming and reservoir operations became difficult to detect in the Jacuí and Guaíba Basin.

The migratory fish species of the Guaíba Basin (S. brasiliensis, P. lineatus, $L$. obtusidens), except $P$. pintado, were not reported above altitudes of 280-300 m (Alves \& Fontoura, 2009). This suggests that operating hydroelectric power generation dams in the Jacuí Basin may not be the only key factor limiting upstream movement of migratory fishes, but the 280-300 m altitudinal profile should be considered in the licensing process of new dams. Besides limiting fish migration, river 
damming changes population structures of flooded areas and limits genetic flow, although direct implications for the Guaíba Basin have yet to be measured.

The status of fish populations in the Jacuí Basin has not been regularly evaluated, but unsystematic sampling programmes and unstructured interviews points to reductions in both abundance and size of captured fishes. Also, migratory fish species are no longer captured in the historical upper limits. Museum records since 1968, however, show that the $C$. carpio is the largest fish species captured, especially in the upper segments of the Jacuí Basin. Other exotic species recorded in the Guaíba Basin and upper Patos Lagoon are M. salmoides (museum record from 1965) and the rainbow trout Oncorhynchus mykiss (Walbaum) (museum record from 1989); restricted to altitudinal areas of the Taquari and Antas and Caí River basins (for M. salmoides), the Nile tilapia Oreochromis niloticus (L.), grass carp Ctenopharyngodon idellus (Valenciennes), following Becker et al. (2007) and the African catfish Clarias gariepinus (Burchell).

From the historical point of view, it is also interesting to identify the gradual appearance of species of the Uruguay Basin in the Patos Lagoon drainage area. These new introductions are P. bonariensis (Sciaenidae; Milani \& Fontoura, 2007), Acestrorhynchus pantaneiro Menezes (Characidae; Pereira et al., 2006) and P. corruscans (Pimelodidae). The first two species are being captured on a regular basis and are established species. The mechanism of Uruguay species introduction is unknown, but the prevailing hypothesis concerns the relative proximity of the upper Vacacaí (Jacuí Basin) and Ibicuí (Uruguay Basin) to an area of intense rice farming, with water pumping and effluent discharged to both drainages.

Agriculture is widespread all over the Patos Lagoon Basin. There is an increasing production of loblolly pine Pinus taeda in the highlands, soybean, corn and wheat at average altitudes, and rice production in the wetlands around the lagoons and downstream segments of the main rivers. Riparian vegetation is greatly depleted, and the plantation areas frequently reach the river margins, resulting in sediment and nutrient inputs. Rice is usually produced in drained wetlands, which are a specialized habitat for rivulids (Cyprinodontiformes) (Table II). Wetlands are also important nursery habitats for several species (S. brasiliensis, P. lineatus and L. obtusidens) in marginal lagoons of downstream segments of the Jacuí Basin or for nesting $(H$. malabaricus) all over the Patos Lagoon Basin. Industrial pollution is under control with strong legal enforcement, although most domestic effluent is still untreated. Massive fish mortality, $>80 \mathrm{t}$, was recorded for the lower Sinos Basin in 2006, a result from the synergistic effects of untreated domestic effluent, low water levels and illegal industrial discharge. Sand mining is especially important in low river segments of the Guaíba basin and affects water quality by suspending sediments and modifying the marginal topography. The main problem concerns areas with dangerous heavy metal contaminations (zinc, nickel, mercury and arsenic) that may be due to old industrial discharges in times when these effluents were not treated or monitored.

In the Patos Lagoon, some species have a wide distribution, from the marine region to freshwater areas in the northern part of the lagoon, especially estuarine dependent and estuarine resident species. Based on spatial and temporal distribution, the estuarine fish fauna of Patos Lagoon was divided into deeper water, shallow water and pelagic associations (Vieira \& Castello, 1997). The major components of the deeper water estuarine association are epibenthic (e.g. M. furnieri, G. barbus 
TABLE II. List of endangered freshwater fish species for the Patos Lagoon. Freshwater species according to Reis et al. $(2003 a, b)$ and estuarine species following Becker et al. (2007)

\begin{tabular}{|c|c|c|c|c|}
\hline Order & Family & Species & Status & Distribution \\
\hline \multirow[t]{2}{*}{ Characiformes } & Characidae & $\begin{array}{l}\text { Bryconamericus } \\
\text { lambari }\end{array}$ & Vulnerable & $\begin{array}{c}\text { Endemic species } \\
\text { of Feitoria } \\
\text { Stream, upper } \\
\text { Caí Basin }\end{array}$ \\
\hline & & $\begin{array}{l}\text { Salminus } \\
\quad \text { brasiliensis }\end{array}$ & Vulnerable & $\begin{array}{l}\text { Main rivers of } \\
\text { the Patos } \\
\text { Basin }\end{array}$ \\
\hline Siluriiformes & Callichthyidae & $\begin{array}{l}\text { Lepthoplosternum } \\
\text { tordilho }\end{array}$ & Endangered & $\begin{array}{c}\text { Endemic species } \\
\text { of lower Jacuí } \\
\text { and Guaíba }\end{array}$ \\
\hline \multirow[t]{4}{*}{ Cyprinodontiformes } & Rivulidae & $\begin{array}{c}\text { Austrolebias } \\
\text { cyaneus }\end{array}$ & Endangered & $\begin{array}{c}\text { Endemic species } \\
\text { of wetlands of } \\
\text { lower Jacuí }\end{array}$ \\
\hline & & $\begin{array}{c}\text { Austrolebias } \\
\text { minuano }\end{array}$ & Endangered & $\begin{array}{c}\text { Endemic species } \\
\text { of wetlands } \\
\text { around Rio } \\
\text { Grande city }\end{array}$ \\
\hline & & $\begin{array}{l}\text { Austrolebias } \\
\text { nigrofasciatus }\end{array}$ & Endangered & $\begin{array}{l}\text { Endemic species } \\
\text { of wetlands of } \\
\text { the west } \\
\text { drainage of } \\
\text { the Mirim } \\
\text { Lagoon }\end{array}$ \\
\hline & & $\begin{array}{l}\text { Megalebias } \\
\quad \text { wolterstorffi }\end{array}$ & $\begin{array}{l}\text { Critically } \\
\text { endangered }\end{array}$ & $\begin{array}{l}\text { Endemic species } \\
\text { of wetlands of } \\
\text { Guaíba and } \\
\text { northern Patos } \\
\text { Lagoon }\end{array}$ \\
\hline
\end{tabular}

and G. genidens) and demersal fish species [e.g. M. ancylodon, M. americanus, Paralonchurus brasiliensis (Steindachner), C. guatucupa, Umbrina canosai Berg], which comprise an important portion of the southern Brazilian, Uruguay and Argentina fishing industry. Throughout the year, juveniles and sub-adults of M. furnieri, Genidens spp. and sub-adults of P. brasiliensis, M. ancylodon and M. americanus use the Patos Lagoon as a feeding ground and represent the dominant components in the main channel and adjacent areas.

Shallow waters $(<2 \mathrm{~m})$ are typically dominated by small estuarine resident fishes (Atherinidae, Anablepidae) and juveniles of estuarine dependent marine species of Mugil spp. and M. furnieri. Together, these species make up $90 \%$ in number of beach seine catches and display three clearly defined annual abundance peaks (Chao et al., 1985). Young individuals of Mugilidae species $\left(<50 \mathrm{~mm} L_{\mathrm{T}}\right)$ compose $42 \%$ of the total catch. Mugil curema Valenciennes and Mugil sp. occur during summer and autumn, while Mugil platanus Günter is present throughout the year, with peak abundance from late winter to early summer. 
Atherinidae species are present throughout the year and total c. $30 \%$ of the catch. The peak abundance of Atherinella brasiliensis (Quoy \& Gaimard) and Odontesthes argentinensis (Valenciennes) occurs during the autumn and winter and winter and spring, respectively. The pelagic species $\left(L_{\mathrm{T}}<120 \mathrm{~mm}\right)$ L. grossidens, A. marinii, Engraulis anchoita Hubbs \& Marini, and juveniles of Peprilus paru (L.) and Selene setapinnis (Mitchill), represent $40 \%$ of midwater catches (Chao et al., 1985). Plankton-feeding juveniles of the clupeids Brevoortia pectinata (Jenyns), Ramnogaster arcuata (Jenyns) and Platanichthys platana (Regan) are abundant in shallower areas.

Years of low abundance of fishes seem to coincide with periods of high rainfall and low salinity during El Niño events, which decreases recruitment of resident and estuarine dependent fish species, though species richness increases due to an expanded range of freshwater species [Parapimelodus nigribarbis (Boulenger)] into the estuary (Garcia et al., 2003). Due to lower or higher precipitation and freshwater outflow, the abundance of marine species in the estuary increases or decreases during La Niña (1995-1996) or El Niño (1997-1998) events, respectively (Garcia et al., 2001, 2004).

Landing statistics are not available on a regular basis for the whole basin. According to Milani \& Fontoura (2007), fisheries in the northern Patos Lagoon capture 18 different species as recorded by local names, but that may include 24 nominal species. Four of them are responsible for $85 \%$ of the catches: viola Loricariichthys anus (Valenciennes), H. malabaricus, M. platanus and the marine catfish Genidens spp. are responsible for $85 \%$ of the total catches. A legally enforced closed season aims at protecting the $L$. anus and $H$. malabaricus breeding stocks.

The commercial fishery never stops, not even during closed seasons, as result of deficient control and poor law enforcement. Loricariichthys anus is probably under severe pressure owing to a low fecundity (male lip brooding) and a reproductive period restricted to November to February, with increased seasonal captures despite legal enforcement. For this fishery, special gillnets are used, with an illegal mesh-size $(<70 \mathrm{~mm})$ and set just over the bottom and only $60-70 \mathrm{~cm}$ high. As these gillnets do not reach the water surface, they are not identified, and fishes are extracted at night or early in the morning with no control. Hoplias malabaricus is not affected directly by fisheries during the breeding period (November to February). During this period, this species moves to flooded wetlands to breed, escaping fisheries pressure. It is suffering pressure from increased drainage of wetlands, which may limit available habitats for nesting and reproduction, although the species is found inside rice fields (Rodrigues, 2009).

In the estuarine region, M. furnieri, M. platanus, Genidens spp. and Pogonias cromis (L.) sustain small-scale fisheries in the estuary, although landing and catch per unit effort data are underestimated. The decline of artisanal fish stocks can be attributed to inadequate fishery surveillance by government sectors, which led to overfishing and mortality of juveniles during the reproductive seasons (Chao et al., 1985; Haimovici \& Umpierre, 1996; Haimovici et al., 1997, 2006; Reis et al., 1994) or may be due to decreasing water quality as a result of urban and industrial activities and power production in the Patos Lagoon catchment (Asmus, 1997; Almeida et al., 1993; Alves \& Fontoura, 2009; Odebrecht et al., 2010). Climatic events may also mask the causes of fish stock declines in the estuary since they affect the structure of the fish fauna and the recruitment of economically important species (Garcia et al., 
2003, 2004; Odebrecht et al., 2010). Indeed, intense local and oceanic fisheries seem to act synergistically with ENSO events and have led eventually to the depletion of estuarine fish stocks such as Mugilidae since their abundance depends on saltwater intrusion (Vieira et al., 2008). Depletion of stocks inside the Patos Lagoon does not accord with recorded landings for São Paulo coastal areas, which concern basically the same reproductive population. Meteorological changes caused by the ENSO phenomenon may partly be the cause of the declines and hence of great economical and social impact (Castello \& Möller, 1978; Möller et al., 2001; Garcia et al., 2004).

Global warming also represents a major threat to the Patos system not only by changing the frequency of ENSO events. The lagoon itself was essentially a large estuary in the climatic optimum of 4 to $5 \times 10^{3}$ years ago, with two other connections with the ocean, the palaeochannels of the Guaíba and Camaquã River drainages, as identified by sediment sonar exploration (Weschenfelder et al., 2008). With a rise in the sea level, not only the estuarine limits will move to the northern Patos Lagoon but there is a risk of disruption of the ancient channels, demanding engineering intervention to maintain the community structure.

\section{PRIORITIES AND RECOMMENDATIONS FOR CONSERVATION}

\section{AQUATIC PROTECTED AREAS FOR BIODIVERSITY CONSERVATION}

Threats to estuarine and coastal fish habitats can come from a number of sources and develop into a myriad of problems, many of them recurrent as dissolved oxygen depletion (Fig. 3). Another characteristic of these threats is that they usually happen as a sequence of events or in conjunction. Ultimately, the resulting processes will lead to habitat loss. Habitat loss may be radical, when a whole habitat disappears from the landscape, or subtle, when it starts to gradually lose its attributes, services and quality with respect to nursery, feeding grounds or shelter for reproduction and from predators. Eventually, the decreased quality of services will be reflected in communities, populations and individuals. The full process may result in a range of ecological as well as social issues or costs. Fishes are sensitive to all these changes, and the correct choice of guild or guilds to study in an ecosystem can reveal, quite accurately, the nature and degree of such transformations (Costa et al. 2009).

Information is often only partially available in the form of academic documents (monographs, dissertations and theses) or government reports in native languages. Although these contain important information for habitat conservation and scientific advancement, there is a pressing need for South American scientists to publish internationally. For this reason, the present review hopes to make an important contribution by bringing to the international scene, information previously only available locally or within regional institutions. Encouraging leading South American scientists to produce reviews of this kind helps optimize the availability of information.

There is still a lack of simple inventories of fishes and, especially of, other aquatic organisms. Taxonomic and systematic studies of South American fishes are still deficient, so the real biodiversity may be underestimated. Inventory initiatives should be pursued soon, as many aquatic environments are under threat of disappearing completely and permanently (e.g. Sete Quedas Falls, Paraná Basin). Baseline studies 


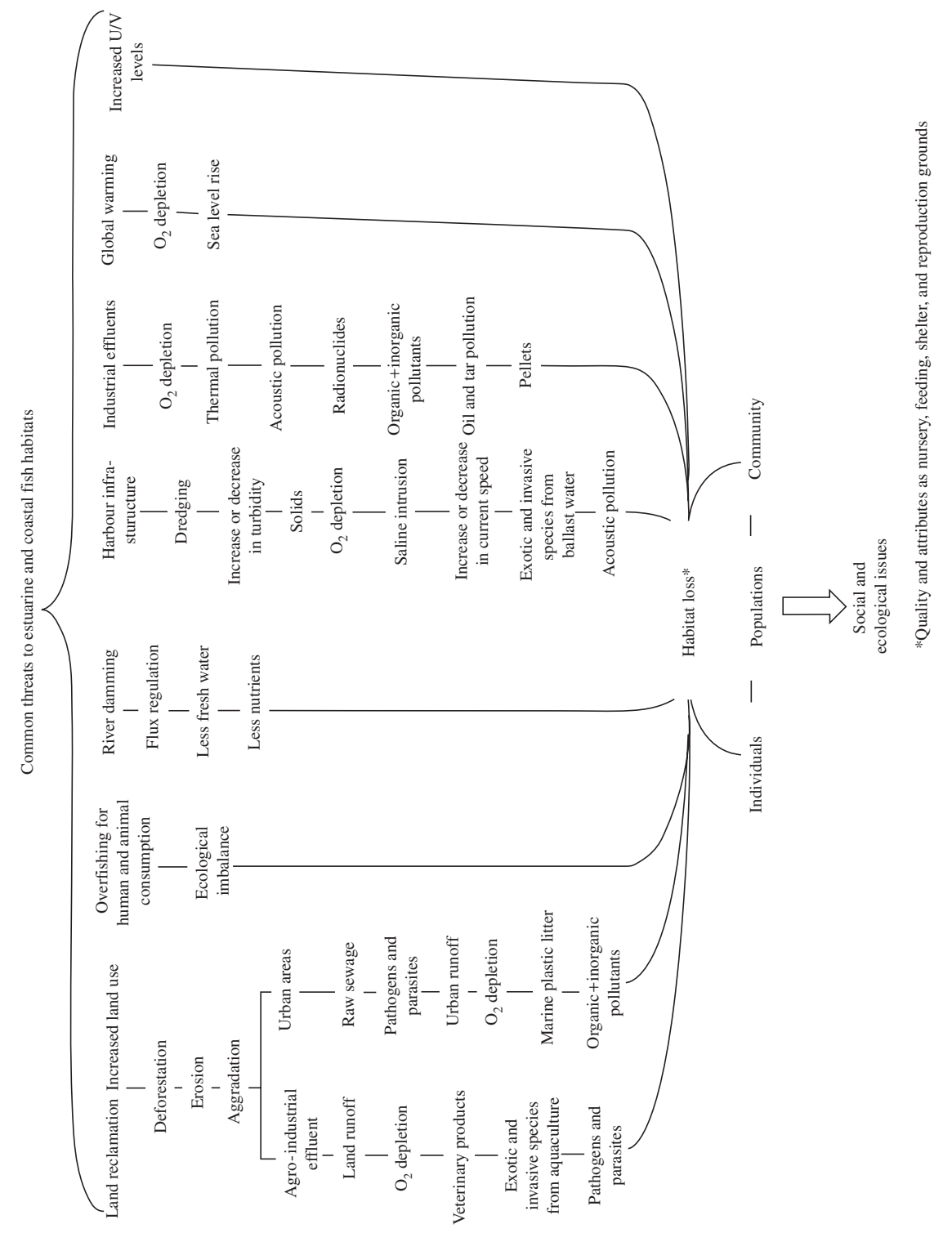

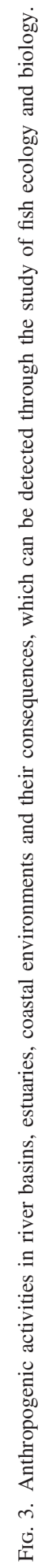


of hydrology, physico-chemical and ecological and biological integrity of streams are essential if the goal is their conservation. Basic life-history studies for most of the commercially exploited fish species are missing completely or are incomplete and insufficient.

The establishment of aquatic protected areas (headwaters, riparian vegetation, coastal forests and their connected habitats with nursery and other important ecological roles) has not started until recently on the continent. These initiatives have secured many different levels of protection status for the main aquatic habitats but still remain concentrated around relatively small areas and are not completely effective. The different levels of environmental protected areas, such as national and state parks, and extractive protected areas (RESEX) are established and managed by the government. Private conservation units also exist, especially around freshwater habitats and are responsible for the protection of some important habitats across river basins.

The long-term environmental effects of dam construction have not been adequately taken into account when planning or operating these structures. When true costbenefit studies include the environmental costs, few projects would be found to be feasible. The long-term studies of the effects of existing dams need to be undertaken, to make better informed decisions about future projects. Emphasis on the biological integrity of streams should redirect water quality assessment. The effects of deforestation should be studied and reforestation projects urgently started, especially to protect riparian habitats crucial to many fishes (Rodríguez et al., 2007).

When dams in the Amazon are considered, management directives should be profoundly reviewed; new approaches are fundamental to the expansion of dams in that region. The first of these includes an increase in basin surveys. Currently, these studies are restricted to areas of hydroelectric power generation potential, and a diagnosis of the biota should be required by the time the dam building starts (implementation phase). Such data are necessary to adequately predict the consequences of the new dams and, most importantly, to identify the critical habitats for the life cycles of fish species. In addition, these data are needed to plan the occupation of a basin, allowing areas to be prioritized and selected for all purposes, not the least for conservation. The second approach refers to the obvious need to evaluate the outcomes (results and consequences) of the actions implemented. Therefore, monitoring should be strongly coupled with management and serve as a source of knowledge, providing information with which to evaluate an action and subsequently review the management plans whenever necessary.

Despite fish habitat changes and losses, actions towards fishes and fisheries sustainability from the Colombian Government through the Agriculture and Rural Development Ministry are focused solely on fisheries regulation (e.g. closed seasons, minimum capture sizes and gear specifications) and compensatory measures (e.g. stocking and aquaculture). More consistent and systemic measures are urgently needed.

Management strategies should be developed taking into account the characteristics resulting from evolutionary selection of traits, which permit the species to adapt to the types of environment in which they occur and enable them to respond to threats in their environment. Fish distribution in the Amazon can be considered the result of adaptations. There is reasonable evidence that regional processes influence both regional and local diversity. There is no single explanation, however, for species 
richness in different parts of the world. Thus, ecology, evolution, biogeography, systematics and palaeontology are all required to understand global patterns of fish diversity (Val et al., 2006).

Due to the importance of species-habitat relationships, life strategies and the effect of movement patterns, it is suggested that migrations should be considered ecological and evolutionary phenomena that allow connectivity between habitats and promote renewal of demographic groups (population patches). Migration is a strategy to further exploit and use ephemeral habitats and transcends each species. To know the home range of a species targeted for special conservation status is fundamental in formulating the strategy to protect it. Genetic studies have advanced rapidly in the Amazon Basin (Hrbek et al., 2005; Santos et al., 2007; Machado, 2009) and a wide genetic variability has arisen as an important result, together with the indication of poorly structured populations. Metacommunities is then a possible approach to study fishes in the region (Granado-Lorencio et al., 2005).

Spatial changes in community structure, species demographics and genetic flow among habitats and sub-basins will be the future challenges to fish biologists in the Amazon Basin. The bridging of some of these knowledge gaps will help better explain the factors that determine fish assembly variables (structure, diversity and abundance) at local, regional and basin-wide scales, allowing for the best possible conservation measures.

The Brazilian Environmental Authority has implemented conservation units of sustainable use (e.g. extractive protected areas, RESEX), which are not sufficient for a total protection of the ecosystems, as these protected areas are designated for the conservation and sustainable management of natural resources by the traditional communities inhabiting them. So far, the designation of RESEX has been opportunistic and the geographic boundaries of these conservation units have been selected based on non-ecological considerations related to the social and economic interests of local governments and community organizations. The results from this review highlight the need for more ecological and biological studies to obtain data (e.g. on nursery ground value and habitat connectivity) not only to implement the management plans of existing protected areas but also to identify the location and extent of conservation units in the future.

There are present and urgent challenges that should be understood more fully in order to guarantee fish habitat conservation in the mangrove-lined estuaries of Brazil: (1) how spatial patterns in fish habitat use are related to landscape features, (2) how the biological connectivity operates in mangrove ecosystems and what is the ecological role of each habitat, (3) how the temporal and spatial change in benthic invertebrates affect the feeding ecology of the intertidal mangrove fish species, (4) how the contribution of the autotrophic sources to fish changes along an estuarine gradient and in relation to seasonal variation and (5) what are the direct and indirect effects of commercial fishing activities on intertidal habitats.

Future dredging operations for maintenance of shipping channels giving access to port facilities should be avoided during periods of fish reproduction and recruitment. Seasonal rainfall patterns and other environmental variables vary greatly along the Brazilian coast. If similar measures regarding dredging or any other large anthropogenic interventions are to be implemented in other regions of Brazil and other countries around the tropical and subtropical belt, the seasonal regimes and their 
consequences to the estuarine communities should be documented before decisionmaking (M. Barletta, M.F. Costa, A.C.R. Couto, M.F.M. Corrêa \& U. Saint-Paul, unpubl.data). Laws regulating fisheries inside the estuaries are based on areas, gears and periods of reproduction of the fishes and invertebrates. At the continental shelf, policy is similar: fishing is controlled according to the minimum size for catching, while shrimp fishing considers the period allowed for catching (Robert \& Chaves, 2001). These variables are obtained by integrating the reproductive attributes of species, such as size at first maturation and period and area of spawning, with knowledge about the occupation habits of species in the estuary and its vulnerability to fishing gears (Souza \& Chaves, 2007).

The short-term conservation objectives for the La Plata Basin and its coastal areas (SWACS) might be reached without much ecosystem information, but long-term objectives, important for the conservation of the structure and functioning of the entire ecosystem, require strategies that incorporate interspecific relationships and habitats. Therefore, identifying the main environmental characteristics of habitats required by a fish throughout its life-history stage, and environmental influences on connectivity between habitats, is vital for studying population dynamics, managing fish stocks, delineating essential fish habitat and designing marine protected areas. Developing models in areas with persistent fish community structures (defined according to fish assemblages) could be useful for SWACS management and conservation in relation to the structure and functioning of the entire ecosystem (riverine, estuarine, coast and shelf).

The information for some species shows that the habitats required by many fishes throughout their life history occur under different political jurisdictions (e.g. Argentina, Uruguay and Brazil). Assuming a single population, a management strategy must involve the complete distribution range to manage effectively the fish populations of the SWACS. Thus, studies to effectively validate the interconnection (e.g. otolith chemistry, satellite tracking, genetics and growth) between jurisdictions should be carried out in the near future.

\section{Conservation genetics}

DNA technology has been considered worldwide as one of the most remarkable revolutions for the study of biodiversity, especially for the neotropical biota, given its incomparable diversity. Regarding molecular data, similar patterns can also be observed and new and intense research is urgently needed, given the very large biodiversity, the habitat loss and human impacts.

Chromosomal analyses as tools for testing species cohesiveness have shown several very interesting patterns of population genetic aggregation, since slight to narrow connectivity functions as continuous and discontinuous environments. For instance, karyotype-based studies in populations of $H$. malabaricus and in the blue tetra Mimagoniates microlepis (Steindachner) demonstrated a striking population discontinuity occurring within the species resulting from a long-term isolation period imposed by Serra do Mar chains in southern Brazil (Guimarães et al., 1995; Bertollo et al., 2000; Vicari et al., 2006; Torres et al., 2008). Artoni et al. (2009) demonstrated two biological patterns regarding karyotypical differentiations by karyotyping 627 specimens belonging to 13 species from Campos Sulinos in the state of Paraná (southern Brazil), suggesting that regions hosting variable karyotypes should be the primary focus of conservation efforts, given possible high unrecognized species richness. In 
the marine environment, $M$. curema is a very interesting phenomenon depicting an unexpected, but possible pattern of population discontinuity in a wide ranging species by karyotype-based methods (LeGrande \& Fitzsimons, 1976; Nirchio \& Cequea, 1998; Nirchio et al., 2003, 2005). Such data with others from meristics and morphology resulted in the detection of a new taxon (Mugil rubrioculus Harrison, Nirchio, Oliveira, Ron \& Gaviria) from the Caribbean province (Harrison et al., 2007).

In marine environments, allopatry-based population differentiation may also be a part of the phenomenon regarding population discontinuity with putative speciation. The Panamá Isthmus is considered one of the most evident physical barriers in terms of Atlantic and Pacific Ocean communications, including biota exchange. Epinephelus itajara (Lichtenstein) is one of the most threatened fish species worldwide. The species was included in the world Red List by IUCN as a species critically threatened. In 2002, a joint action by several institutions acquired the approval with the Brazilian Environmental Institute and from the Ministry of Environment the law of protection to E. itajara along the whole Brazilian Economic Exclusive Zone. In addition, close genetic relationships have been identified for this species in the western Atlantic Ocean (Craig et al., 2009). Such information is crucial in terms of the species conservation, given that a putative genetic depletion in one region could implicate the alteration of the historical demography in the other region. Studies on coral reef fishes have demonstrated a clear population genetic division between close but ecologically different habitats and high species cohesiveness between similar habitats separated by thousands of kilometres (Rocha et al., 2005).

In an ecological sense, DNA bar-coding procedures can also be used for a broad biodiversity assessment (current biodiversity and palaeoecology) and diet composition (Valentine et al., 2008). Forensic genetics host several DNA technologies in order to answer the four most common casework questions: What species is it? Where did it come from? Was it captive bred? (Ogden et al., 2009). In terms of direct applications, DNA bar-coding procedures enable (1) provision of methods of high technological rigour to non-experts or users of natural resources with regard to identifying biodiversity in biomedicine (parasites and vectors), in agriculture (pests) or in the cases of conservation issues and (2) recognition of several organisms at diverse development stages (Hajibabaei et al., 2007).

Wildlife DNA forensics is essentially concerned with the identification of evidence items in order to determine the species, population, relationship or individual identity of a sample. With the development of national and international legislation to protect ever-diminishing habitat and species diversity, DNA forensics is now becoming a key investigative tool to combat wildlife crime (Ogden et al., 2009). Given the incomparable biodiversity subjected to real threats in the region and the large amount of exploitable species that have almost no protecting laws, it is important to suggest such DNA technology as an ever stimulating obligate routine by governmental environmental bureaux in South America. Very few studies in South America have so far made use of such genetic tools. It suggests that possibly there are no investments, motivation or interests in applying a tremendous amount of knowledge for a rational use of fish resources.

Studies in the Amazon Basin depict such a situation, given its very large fish biodiversity, few working scientists, the true threats over the whole biome by the advance of agricultural boundaries and disordered human population expansion. The 
conservation genetics studies of A. gigas could be considered a landmark model of analysis focussed on protecting Amazon fishes (Hrbek et al., 2005, 2007). In the south, work on $P$. corruscans is also a striking example of conservation genetics of fishes of the La Plata Basin (Pereira et al., 2009).

In the marine environment, genetics studies on Sciaenidae, especially those on M. ancylodon and C. acoupa (Santos et al., 2003, 2006; Rodrigues et al., 2008), are also an exceptional example of a fisheries genetic approach, given their importance in fish landings (Barletta et al., 1998).

The issues discussed above show the need for constant monitoring of fish species (harvested, endangered or not) as well as their habitats. Such recommendations are closely linked to the expansion and development status of human populations as well as patterns of habitat and resources use. Developed nations will be those that recognize the importance of aquatic habitats and biological conservation and turn their investments to the way of a revolutionary social and economic condition (Torres, 2003).

\section{CONCLUSIONS}

Once causal relationships between sources of impact and its consequences are consistently established, based on scientific knowledge, it will be possible to implement far more robust sample designs to be used in monitoring and ecosystem comparisons. Some of these interactions are actually linked to desirable interventions, such as tourism and artisanal fishing. Nevertheless, even these activities need to be planned and monitored. A compromise will always be needed between socio-economic sustainability and some environmental loss. Effects need to be detected, quantified and diagnosed through the study of fish species or assemblages. Since they are acting upon the whole system, integrated approaches will be needed.

Another issue is the adaptation of models developed for other regions, socioeconomic situations and technological stages. For instance, South American native fishes and their larvae are sometimes used as toxicological models; these initiatives are highly valuable in establishing local models, nearer to real situations.

Aquatic ecology may be understood from many different viewpoints. Fishes are key elements in describing a number of ecosystem features, including the different levels of anthropogenic interference. Fishes may be successfully used as bioindicators of chemical pollution. The same approach can be used from watershed to ocean, integrating the whole basin in a single ecocline where positive and negative scores are integrated. The most commonly used forms of anthropogenic interference assessment using fishes are the traditional chemical analysis of muscle tissues (and sometimes stomach contents) and the detection of physiological and genetic biomarkers. Population and community variables are also necessary to describe environmental changes induced by human use and activities in rivers, lakes, reservoirs, estuaries and coastal waters.

In developing countries, such as most of the South American nations, it is believed that environmental pressures are still increasing and that turning the situation in favour of the environment and all South Americans will require a longer time and greater effort than is currently seen in developed countries. This is due largely to the regional differences in development levels within the continent and partially 
to the geographic scale of the work. There are a number of initiatives to reverse habitat loss and poor water quality standards in a number of water environments throughout South America. Are such managerial actions working? Monitoring is costly and difficult in terms of wide areas (whole basins) to cover and long periods of time (season and years) to support the activity. So it may not always be the best approach. Herein lies the relevance of existing and future scientific work for the decision-makers. Only through the establishment of a sound scientific basis will it be possible to acquire good data records. In addition, the recent interest in and increase in the relevance of environmental records is helpful. In the case of aquatic environments, one of the most precious environmental records (sediments) is nearly always present. Others of biological origin may also be very useful (otoliths and bones). Biogeochemical records of natural and anthropogenic nature can be used as well as biotic and abiotic markers to underpin management of environmental quality, habitat conservation, ecological services and sustainability.

In an ideal world, an understanding of how fish assemblages change in response to natural changes along different time scales would be necessary before intervening in their environments. This is no longer always possible, however, since most aquatic environments are already subject to some form of human intervention, and severe transformations are more the rule than the exception. Therefore, it is necessary to deal with mixed signals, and part of the challenge lies in numerically distinguishing these signals, as well as putting them in perspective.

M.B., N.F.F., A.A.A., V.A.V., A.L.V., R.A.T., N.N.F., V.B., P.T.C. and J.P.V. are recipients of research fellowships from CNPq. The authors thank S. J. M. Blaber and two anonymous reviewers for their important contributions to earlier versions of this manuscript.

\section{References}

Abujanra, F., Agostinho, A. A. \& Hahn, N. S. (2009). Effects of the flood regime on the body condition of fish of different trophic guilds in the Upper Paraná River floodplain, Brazil. Brazilian Journal of Biology 69 (Suppl. 2), 469-479.

Agostinho, A. A. \& Gomes, L. C. (1997). Manejo e monitoramento de recursos pesqueiros: perspectivas para o reservatório de Segredo. In Resevatório de Segredo: Bases ecológicas para o manejo (Agostinho, A. A. \& Gomes, L. C., eds), pp. 319-364. Maringa: Universidad Estadual de Maringa.

Agostinho, A. A., Gomes, L. C., Susuki, H. I. \& Julio, H. F. Jr. (2003). Migratory fishes of the Paraguay-Paraná basin, Brazil. In Migratory Fishes of South America. Biology, Fisheries and Conservation Status (Carolsfeeld, J., Harvey, B., Ross, C. \& Baer, A., eds), pp. 19-99. Ottawa, ON: World Fisheries Trust/World Bank/IDRC 2004.

Agostinho, A. A., Gomes, L. C., Veríssimo, S. \& Okada, E. K. (2004). Flood regime, dam regulation and fish in the Upper Paraná river: effects on assemblage attributes, reproduction and recruitment. Reviews in Fish Biology and Fisheries 14, 11-19.

Agostinho, A. A., Gomes, L. C. \& Pelicice, F. M. (2007a). Ecologia e manejo de recursos pesqueiros em reservatórios do Brasil. Maringa: EDUEM.

Agostinho, A. A., Marques, E. E., Agostinho, C. S., Almeida, D. A., Oliveira, R. J. \& Melo, J. R. B. (2007b). Fish ladder of Lajeado Dam: migrations on one-way routes? Neotropical Ichthyology 5, 121-130.

Agostinho, A. A., Pelicice, F. M. \& Gomes, L. C. (2008). Dams and the fish fauna of the Neotropical region: impacts and management related to diversity and fisheries. Brazilian Journal of Biology 68 (Suppl. 4), 1119-1132.

Allan, J., Frenner, A., Erazo, J., Fernández, L., Flecker, A., Karwan, D., Segnini, S. \& Taphorn, D. (2002). Land use in watersheds of the Venezuelan Andes: a comparative analysis. Conservation Biology 16, 527-538. 
Almeida-Val, V. M. F. \& Hochachka, P. W. (1995). Air-breathing fishes: metabolic biochemistry of the first diving vertebrates. In Biochemistry and Molecular Biology of Fishes, Vol. 5 (Hochachka, P. W. \& Mommsen, T., eds), pp. 45-55. Amsterdam: Elsevier.

Almeida-Val, V. M. F., Val, A. L. \& Hochachka, P. W. (1993). Hypoxia tolerance in Amazon fishes: status of an under-explored biological "goldmine". In Surviving Hypoxia: Mechanisms of Control and Adaptation (Hochachka, P. W., Lutz, P. L., Sick, T., Rosenthal, M. \& van den Thillart, G., eds), pp. 435-445. Boca Raton, FL: CRC Press.

Almeida, V. L. L., Resende, E. K., Lima, M. S. \& Ferreira, C. J. A. (1993). Dieta e atividade alimentar de Prochilodus lineatus (Characiformes, Prochilodontidae) no Pantanal do Miranda-Aquidauana, Mato Grosso do Sul, Brasil. Unimar 15 (Supp.), $125-141$.

Almeida-Val, V. M. F., Val, A. L. \& Walker, I. (1999a). Long- and short-term adaptation of Amazon fishes to varying $\mathrm{O}_{2}$-levels: intra-specific phenotypic plasticity and interspecific variation. In Biology of Tropical Fishes (Val, A. L. \& Almeida-Val, V. M. F., eds), pp. 185-206. Manaus: INPA.

Almeida-Val, V. M. F., Paula-Silva, M. N., Duncan, W. P., Lopes, N. P., Val, A. L. \& Land, S. C. (1999b). Increase of anaerobic potential during growth of an Amazonian cichlid, Astronotus ocellatus. Survivorship and LDH regulation after hypoxia exposure. In Biology of Tropical Fishes (Val, A. L. \& Almeida-Val, V. M. F., eds), pp. 437-448. Manaus: INPA.

Almeida-Val, V. M. F., Val, A. L., Duncan, W. P., Souza, F. C. A., Paula-Silva, M. N. \& Land, S. (2000). Scaling effects on hypoxia tolerance in the Amazon fish Astronotus ocellatus (Perciformes, Cichlidae): contribution of tissue enzyme levels. Comparative Biochemistry and Physiology 125B, 219-226.

Almeida-Val, V. M. F., Chippari-Gomes, A. R. \& Lopes, N. P. (2006). Metabolic and physiological adjustments to low oxygen and high temperature in fish of the Amazon. In The Physiology of Tropical Fishes, Vol. 21 (Val, A. L., Almeida-Val, V. M. F. \& Randall, D. J., eds), pp. 443-500. London: Elsevier.

Alonso, J. C. \& Picker, L. (2005). Dinâmica populacional e estado atual de exploração de Piramutaba e de Dourada. In $O$ manejo da pesca dos grandes bagres migradores: Piramutaba e Dourada no eixo Solimões - Amazonas (Fabré, N. N. \& Barthem, R. B., eds), pp. 21-28. Manaus: ProVárzea/IBAMA.

Alvarado, H. \& Gutierrez, F. (2002). Especies hidrobiológicas continentales introducidas y transplantadas y su distribución en Colombia. Bogotá: Ministerio del Medio Ambiente.

Álvarez, E., Balbas, L., Massa, I. \& Pacheco, J. (1986). Aspectos ecológicos del Embalse Guri. Interciencia 11, 325-333.

Alves, T. P. \& Fontoura, N. F. (2009). Statistical distribution models for migratory fish in Jacuí Basin (Brazil). Neotropical Ichthyology 7, 647-658.

Anganuzzi, A. (1983). Estructura de la comunidad de peces del área costera bonaerense. MSc Thesis, Universidad Nacional de Mar del Plata, Brazil.

Angelini, R., Fabré, N. N. \& Silva-Jr, U. L. (2006). Trophic analysis and fishing simulation of the biggest Amazonian catfish. African Journal of Agricultural Research 1, 151-158.

Araújo-Lima, C. A. R. M. \& Goulding, M. (1998). Os Frutos do Tambaqui. Ecologia, Conservação e Cultivo na Amazônia. Belém: Sociedade Civil Mamirauá/CNPq.

Arrington, D. A. \& Winemiller, K. O. (2004). Organization and maintenance of fish diversity in shallow waters of tropical floodplains. In Proceedings of the Second International Symposium of the Management of Large Rivers for Fisheries, Vol. 2, RAP Publication 2004/16 (Welcomme, R. \& Petr, T., eds), pp. 25-36. Bangok: Food and Agriculture Organization and Mekong River Commission, FAO Regional Office for Asia and the Pacific.

Artoni, R. F., Vicari, M. R., Almeida, M. C., Moreira-Filho, O. \& Bertollo, L. A. C. (2009). Karyotype diversity and fish conservation of southern field from South Brazil. Reviews of Fish Biology and Fisheries 19, 393-401.

Asmus, M. L. (1997). Coastal plain and Patos Lagoon. In Subtropical Convergence Environments - The Coast and Sea in the Southwestern Atlantic (Seelinger, U., Odebrecht, C. \& Castello, J. P., eds), pp. 9-12. New York, NY: Springer.

Baigún, C. \& Oldani, N. (2005). Impactos de represas en la baja cuenca del Río de la Plata: Escenarios ecológicos aplicados a recursos pesqueros. In Humedales fluviales de 
América del Sur. Hacia un manejo sustentable (Fundación Proteger, ed.), pp. 475-488. Santa Fe: Fundación Proteger.

Baigún, C., Oldani, N. \& Damme, P. (2010). Represas hidroeléctricas en América Latina y su impacto sobre la ictiofauna. In Peces de la Amazonía boliviana: potencialidades y amenazas (van Damme, P. A., Carvajal, F. \& Molina, J., eds). Cochabamba: IINIA.

Baillie, J. E. M., Hilton-Taylor, C. \& Stuart, S. N. (2004). IUCN Red List of Threatened Species. A Global Species Assessment. Gland and Cambridge: IUCN.

Bailly, D., Agostinho, A. A. \& Suzuki, H. I. (2008). Influence of the flood regime on the reproduction of fish species with different reproductive strategies in the Cuiabá River, Upper Pantanal, Brazil. Rivers Research and Applications 24, 1218-1229.

Barletta, M. (1995). Estudos das comunidades de peixes bentônicos em três áreas do canal principal, próximas à confluência dos rios Negro e Solimões-Amazonas (Amazônia Central-Brasil). MSc Thesis, INPA/UFAM, Manaus, Brazil.

Barletta, M. \& Blaber, S. J. M. (2007). Comparison of fish assemblages and guilds in tropical habitats of the Embley (Indo-West Pacific) and Caeté (western Atlantic) estuaries. Bulletin of Marine Science 80, 647-680.

Barletta, M. \& Costa, M. F. (2009). Living and nonliving resources exploitation in a tropical semi-arid estuary. Journal of Coastal Research SI 56, 371-375.

Barletta, M., Barletta-Bergan, A. \& Saint-Paul, U. (1998). Description of the fishery structure in the mangrove dominated region of Bragança (State of Pará - North Brazil). Ecotropica 4, 41-53.

Barletta, M., Saint-Paul, U., Barletta-Bergan, A., Ekau, W. \& Schories, D. (2000). Spatial and temporal distribution of Myrophis punctatus (Ophichthidae) and associated fish fauna in a Northern Brazilian intertidal mangrove forest. Hydrobiologia 426, 65-74.

Barletta, M., Barletta-Bergan, A., Saint-Paul, U. \& Huboldt, G. (2003). Seasonal changes in density, biomass, and diversity of estuarine fishes in tidal mangrove creeks of the lower Caeté Estuary (Northern Brazilian coast, East Amazon). Marine Ecology Progress Series 256, 217-228.

Barletta, M., Barletta-Bergan, A., Saint-Paul, U. \& Hubold, G. (2005). The role of salinity in structuring the fish assemblages in a tropical estuary. Journal Fish Biology 66, 45-72.

Barletta, M., Amaral, C. S., Correa, M. F. M., Guebert, F., Dantas, D. V., Lorenzi, L. \& Saint-Paul, U. (2008). Factors affecting seasonal variations in demersal fish assemblages at an ecocline in a tropical-subtropical estuary. Journal of Fish Biology 73, $1314-1336$.

Barletta-Bergan, A., Barletta, M. \& Saint-Paul, U. (2002a). Structure and seasonal dynamics of larval fish in the Caeté River in north Brazil. Estuarine, Coastal and Shelf Science 54, 193-206.

Barletta-Bergan, A., Barletta, M. \& Saint-Paul, U. (2002b). Community structure and temporal variability of ichthyoplankton in North Brazilian mangrove creeks. Journal of Fish Biology 61 (Suppl. A), 33-51.

Barthem, R. B. \& Fabré, N. N. (2004). Biologia e diversidade dos recursos pesqueiros da Amazônia. In A pesca e os recursos pesqueiros na Amazônia Brasileira (Ruffino, M. L., ed.), pp. 11-55. Manaus: ProVárzea/IBAMA.

Barthem, R. \& Goulding, M. (1997). Os bagres balizadores: ecologia, migração e conservação de peixes amazônicos. Brasília: CNPq.

Batista, J. S. \& Alves-Gomes, J. A. (2006). Phylogeography of Brachyplatystoma rousseauxii (Siluriformes - Pimelodidae) in the Amazon Basin offers preliminary evidence for the first case of "homing" for an Amazonian migratory catfish. Genetics and Molecular Research 5, 723-740.

Batista, V. S. \& Rêgo, F. N. (1996). Análise de associações de peixes, em igarapés do estuário do Rio Tibiri, Maranhão. Revista Brasileira Biologia 56, 163-176.

Beck, M. W., Heck, K. L. Jr., Able, K. W., Childers, D. L., Eggleston, D. B., Gillanders, B. M., Halpern, B., Hays, C. G., Hoshino, K., Minello, T. J., Orth, R. J., Sheridan, P. F. \& Weinstein, M. P. (2001). The identification, conservation and management of estuarine and marine nurseries for fish and invertebrates. BioScience 51, $633-641$. 
Becker, F. G., Moura, L. A. \& Ramos, R. A. (2007). Biodiversidade. Regiões da Lagoa do Casamento e dos Butiazais de Tapes, Planície Costeira do Rio Grande do Sul. Brasilia: Ministério do Meio Ambiente.

Bertollo, L. A. C., Born, G. G., Dergam, J. A., Fenocchio, A. S. \& Moreira-Filho, O. (2000). A biodiversity approach in the Neotropical Erythrinidae fish, Hoplias malabaricus. Karyotipc survey, geographic distribution of cytotypes and cytotaxonomic considerations. Chromosome Research 8, 603-613.

Bonetto, A. A. (1998). Panorama sinóptico sobre la ictiofauna, la pesca y piscicultura en los rios de la cuenca del Plata, con especial referencia al Parana. Revista de ictiología, Argentina 6, 3-16.

Bonetto, A. A. \& Pignalberi, C. (1964). Nuevos aportes al conocimiento de las migraciones de los peces en los ríos mesopotámicos de la República Argentina. Comunicaciones del Instituto Nacional de Limnología, Santo Tome 1, 1-14.

Bonetto, A. A., Pignalberi, C. \& Cordiviola de Yuan, E. (1965). Contribución al conocimiento de las poblaciones de peces de las lagunas isleñas del Paraná medio. Anais II Congreso Latinoamericano de Zoología, Sao Paulo 2, 131-144.

Bonetto, A. A., Pignalberi, C., Cordiviola de Yuan, E. \& Oliveros, O. (1971). Información complementaria sobre migraciones de peces en la cuenca del Plata. Physis 30, 505-520.

Bonetto, A. A., Canon Veron, M. \& Roldan, D. (1981). Nuevos aportes al conocimiento de las migraciones de peces en el Río Paraná. Ecosur 8, 29-40.

Bracco, R., Puerto, L., Inda, H. \& Castiñeira, C. (2005). Mid-late Holocene cultural and environmental dynamics in Eastern Uruguay. Quaternary International 132, 37-45.

Briggs, J. C. (1996). Global Biogeography. Amsterdam: Elsevier.

Burns, M. D. M., Garcia, A. M., Vieira, J. P., Bemvenuti, M. A., Marques, D. M. L. M. \& Condini, V. (2006). Evidence of habitat fragmentation affecting fish movement between the Patos and Mirim coastal lagoons in southern Brazil. Neotropical Ichthyology 4, $69-72$.

Camilloni, I. \& Barros, V. (2000). The Parana River Response to El Niño 1982-83 and 1997-98 events. Journal of Hydrometeorology 1, 412-430.

Carignan, R. \& Neiff, J. J. (1992). Nutrient dynamics in the floodplain ponds of the Paraná River, Argentina, dominated by Eichhornia crassipes. Biogeochemistry 17, 85-121.

Carvalho, A. R. \& Fabré, N. N. (2006). Da foz do Amazonas aos Andes. Ciência Hoje 39, 64-67.

Castello, L. (2007). Lateral migration of Arapaima gigas in floodplains of the Amazon. Ecology of Freshwater Fish 17, 38-46.

Castello, J. P. \& Möller, O. O. (1978). On the relationship between rainfall and shrimp production in the estuary of the Patos Lagoon (Rio Grande do Sul, Brazil). Atlântica 3, $67-74$.

Castro, A. C. L. (2001). Diversidade da assembléia de peixes em igarapés do estuário do Rio Paciência (MA - Brasil). Revista Atlântica 23, 39-46.

Castro, L. \& Gorzula, S. (1986). The interrelations of the Caroní river basin ecosystem and Hydroelectric power projects. Interciencia 11, 272-277.

Cervigón, F. (1985). The ichthyofauna of the Orinoco estuarine water delta in the west Atlantic coast, Caribbean. In Fish Community Ecology in Estuaries and Coastal Lagoons: Towards an Ecosystem Integration (Yañez-Arancibia, A., ed.), pp. 57-78. Mexico, DF: Unam Press.

Chao, L. N., Pereira, L. E. \& Vieira, J. P. (1985). Estuarine fish community of the dos Patos Lagoon, Brazil: a baseline study. In Fish Community Ecology in Estuaries and Coastal Lagoons: Towards an Ecosystem Integration (Yañez-Arancibia, A., ed.), pp. 429-450. Mexico, DF: Unam Press.

Chao, N. L., Petry, P., Prang, G., Sonneschien, L. \& Tilusty, M. (Eds) (2001). Conservation and Management of Ornamental Fish Resources of the Rio Negro Basin, Amazonia, Brazil - Projeto Piaba. Manaus: Editora da Universidade do Amazonas.

Colombo, J. C., Bilos, C., Remes Lenicov, M., Colauti, D., Landoni, P. \& Brochu, C. (2000). Detritivorous fish contamination in the Río de la Plata estuary: a critical accumulation pathway in the cycle of anthropogenic compounds. Canadian Journal of Fisheries and Aquatic Sciences 57, 1139-1150. 
Colonnello, G., Ayarzaguena, J. \& Aznar, A. (1985). Efecto de la salinidad sobre las comunidades naturales de Los Llanos Altos Orientales. Edo. Anzoátegui (Venezuela). Memoria Sociedad Ciencias Naturales La Salle 45, 65-78.

Costa, M. F., Barbosa, S. C. T., Barletta, M., Dantas, D. V., Kehrig, H. A., Seixas, T. G. \& Malm, O. (2009). Differences in Mercury accumulation in Trichiurus lepturus (cutlassfish) in relation to length, weight and season. Environmental Science and Pollution Research International 16, 423-430.

Cousseau, M. B. (1985). Los peces del Río de la Plata y de su frente marítimo. In Fish Community Ecology in Estuaries and Coastal Lagoons: Towards an Ecosystem Integration (Yañez-Arancibia, A., ed.), pp. 515-534. Mexico: Unam Press.

Cox-Fernandes, C., Podos, J. \& Lundberg, J. G. (2004). Amazonian ecology: tributaries enhance the diversity of electric fishes. Science 305, 1960-1962.

Craig, M. T., Graham, R. T., Torres, R. A., Hyde, J. R., Freitas, M. O., Ferreira, B. P., Hostim-Silva, M., Gerhardinger, L. C., Bertoncini, A. A. \& Robertson, D. R. (2009). How many species of goliath grouper are there? Cryptic genetic divergence in a threatened marine fish and the resurrection of a geopolitical species. Endangered Species Research 7, 167-174.

Cyrus, D. P. \& Blaber, S. J. M. (1987a). The influence of turbidity on juvenile marine fishes in estuaries. Part 1. Journal of Experimental Marine Biology and Ecology 109, 53-70.

Cyrus, D. P. \& Blaber, S. J. M. (1987b). The influence of turbidity on juvenile marine fishes in estuaries. Journal of Experimental Marine Biology and Ecology 109, 71-91.

Dantas, D. V., Barletta, M., Costa, M. F., Barbosa, S. C. T., Possatto, F. E., Ramos, J. A. A., Lima, A. R. A. \& Saint-Paul, U. (2010). Movement patterns of catfishes (Ariidae) in a tropical semi-arid estuary. Journal of Fish Biology 76, 2471-2488. doi: 10.1111/j.10958649.2010.02646.x.

Delfino, R. \& Baigún, C. (1985). Marcaciones de peces en el embalse de Salto Grande, Río Uruguay (Argentina-Uruguay). Revista de la Asociación de Ciencias Naturales del Litoral, Argentina 16, 85-93.

Depetris, P. J. \& Paolini, J. E. (1991). Biogeochemical aspects of South American Rivers: the Paraná and the Orinoco. In Biochemistry of Major World Rivers (Degens, E. T., ed.), pp. 105-125. New York, NY: Wiley.

Díaz de Astarloa, J. M., Aubone, A. \& Cousseau, M. B. (1999). Asociaciones ícticas de la plataforma costera de Uruguay y norte de Argentina, y su relación con los parámetros ambientales. Physis 57, 29-45.

Dingle, H. \& Drake, A. V. (2007). What is migration? BioScience 57, 113-121.

Driedzic, W. \& Almeida-Val, V. M. F. (1996). Enzymes of cardiac energy metabolism in Amazonian teleosts and the freshwater stingray (Potamotrygon hystrix). Journal of Experimental Zoology 274, 327-333.

Dudley, R. (1998). Atmospheric oxygen, giant paleozoic insects and the evolution of aerial locomotor performance. Journal of Experimental Biology 201, 1043-1050.

Espinach Ros, A. \& Delfino, R. (1993). Las pesquerías de la cuenca del Plata en Bolivia, Paraguay, Argentina y Uruguay. In Comisión de Pesca Continental para América Latina. Informe de la sexta reunión del Grupo de Trabajo sobre Recursos Pesqueros Montevideo, Uruguay, 10-13 de mayo de 1993 (COPESCAL, ed.), pp. 36-51. FAO Informe de Pesca No 490.

Espinach Ros, A., Sverlij, S., Amestoy, F. \& Spinetti, M. (1998). Migration pattern of the sábalo Prochilodus lineatus (Pisces, Prochilodontidae) tagged in the lower Uruguay River. Verhandlungen Internationaler Vereinigung Limnologie 26, 2234-2236.

Fabré, N. N. \& Barthem, R. B. (2005). O manejo da pesca dos grandes bagres migradores: piramutaba e dourada no eixo Solimões/Amazonas. Manaus: IBAMA.

Fernandes, R., Agostinho, A. A., Ferreira, E. A., Pavanelli, C. S., Suzuki, H. I., Lima, D. P. \& Gomes, L. C. (2009). Effects of the hydrological regime on the ichthyofauna of riverine environments of the upper Paraná River floodplain. Brazilian Journal of Biology 69 (Suppl. 2), 669-680.

Filippo, P. F. (2008). Marco regulatorio de la pesca marítima, continental y la acuicultura en la República Argentina. Consejo Federal de Inversiones, Buenos Aires, Argentina. 
Fuster de Plaza, M. L. \& Boschi, E. E. (1961). Areas de migración y ecología de la anchoa Lycengraulis olidus (Günther) en las aguas argentinas (Pisces, fam. Engraulidae). Contribuciones del Instituto de Biología Marina (Mar del Plata, Argentina) 1, 127-183.

Galvis, G. \& Mojica, J. I. (2007). The Magdalena River freshwater fishes and fisheries. Aquatic ecosystem health and management 10, 127-139.

García, A. \& Vieira, J. P. (2001). O aumento da diversidade de peixes no estuário da Lagoa dos Patos durante o episódio El Niño 1997-1998. Atlántica, Río Grande 23, 85-96.

Garcia, A. M., Vieira, J. P. \& Winemiller, K. O. (2001). Dynamics of the shallow-water fish assemblage of the Patos Lagoon estuary (Brazil) during cold and warm ENSO episodes. Journal of Fish Biology 59, 1218-1238.

Garcia, A. M., Raseira, M. B., Vieira, J. P., Winemiller, K. O. \& Grimm, A. M. (2003). Spatiotemporal variation in shallow-water freshwater fish distribution and abundance in a large subtropical coastal lagoon. Environmental Biology of Fishes 68, 215-228.

Garcia, A. M., Vieira, J. P., Winemiller, K. O. \& Grimm, A. M. (2004). Comparison of the 1982-1983 and 1997-1998 El Niño effects on the shallow-water fish assemblages of the Patos Lagoon estuary (Brazil). Estuaries 27, 905-914.

Giarrizzo, T. \& Krumme, U. (2007). Spatial differences and seasonal cyclicity in the intertidal fish fauna from four mangrove creeks in a salinity zone of the Curuçá estuary, north Brazil. Bulletin of Marine Science 80, 739-754.

Giarrizzo, T. \& Krumme, U. (2008). Heterogeneity in intertidal fish fauna assemblages along the world's longest mangrove area in northern Brazil. Journal of Fish Biology 72, $773-779$.

Giarrizzo, T. \& Krumme, U. (2009). Temporal patterns in the occurrence of selected tropical fishes in mangrove creeks: implications for the fisheries management in north Brazil. Brazilian Archives of Biology and Technology 52, 679-688.

Gómez, S. E., Cassará, H. \& Bordone, S. (1994). Producción y comercialización de los peces ornamentales en la República Argentina. Revista de Ictiología, Corrientes 2/3, 13-20.

Granado-Lorencio, C., Lima, C. R. M. A. \& Lobón-Cerviá, J. (2005). Abundance-distribution relationships in fish assembly of the Amazonas floodplain lakes. Ecography 28, $515-520$.

Grosser, K. M. \& Hahn, S. D. (1981). Ictiofauna da Lagoa Negra, Parque estadual de Itapuã, Município de Viamão, Rio Grande do Sul, Brasil. Iheringia (Serie Zoologie) 59, 45-64.

Gubiani, E. A., Gomes, L. C., Agostinho, A. A. \& Okada, K. O. (2007). Persistence of fish populations in the upper Paraná River: effects of water regulation by dams. Ecology of Freshwater Fish 16, 191-197.

Guderley, H. E. \& Gawlicka, A. (1992). Qualitative modification of muscle metabolic organization with thermal acclimation of rainbow trout, Oncorrhynchus mykiss. Fish Physiology and Biochemistry 10, 123-132.

Guerrero, R. A. \& Piola, A. R. (1997). Masas de agua en la plataforma continental. In El Mar Argentino y sus Recursos Pesquero, Tomo I: Antecedentes históricos de las exploraciones en el mar y las características ambientales (Boschi, E., ed.), pp. 107-119. Mar del Plata: Instituto Nacional de Investigación y Desarrollo Pesquero.

Guimarães, I. N., Almeida-Toledo, L. F., Oliveira, C., Foresti, F. \& Filho, S. A. T. (1995). Cytogenetic studies of three species of Glandulocaudinae (pisces, Characiformes, Characidae). Revista Brasileira de Genética 18, 185-189.

Haimovici, M. \& Umpierre, R. G. (1996). Variaciones estacionais en la estructura poblacional del efectivo pesquero de corvina blanca Micropogonias furnieri (Desmarest, 1823) en extremo sur de Brasil. Atlântica 18, 179-203.

Haimovici, M., Castello, J. P. \& Vooren, C. M. (1997). Fisheries. In Subtropical Convergence Environments: The Coast and Sea in the Southewestern Atlantic (Seeliger, U., Odebrecht, C. \& Castello, J. P., eds), pp. 183-196. New York, NY: Springer.

Haimovici, M., Vasconcellos, M., Kalikoski, D. C., Abdalah, P., Castello, J. P. \& Hellembrandt, D. (2006). Diagnóstico da pesca no litoral do Rio Grande do Sul. In Projeto RECOS: Uso e apropriação dos recursos costeiros. Grupo Temático: Modelo Gerencial da pesca. A pesca marinha e estuarina do Brasil no início do século XXI: recursos, tecnologias, aspectos socioeconômicos e institucionais (Isaac, V. J., Martins, A. S., Haimovici, M. \& Andriguetto, J. M., eds), pp. 157-180. Belém: UFPA. 
Hajibabaei, M., Singer, G. A. C., Herbert, P. D. N. \& Hickey, D. A. (2007). DNA barcoding: how it complements taxonomy, molecular phylogenetics and population genetics. Trends in Genetics 23, 167-172.

Hamilton, S. K. (1999). Potential effects of a major navigation project (Paraguay-Paraná hidrovia) on inundation in the pantanal floodplains. Regulated Rivers Research \& Management 18, 289-299.

Hammer, C. \& Purps, M. (1996). The metabolic exponent of Hoplosternum littorale in comparison with Indian air-breathing catfish, with methodological investigation on the nature of metabolic exponent. In Physiology and Biochemistry of the Fishes of the Amazon (Val, A. L., Almeida-Val, M. F. \& Randall, D. J., eds), pp. 283-297 Manaus: INPA.

Harrison, I. J., Nirchio, M., Oliveira, C., Ron, E. \& Gaviria, J. (2007). A new species of mullet (Teleostei: Mugilidae) from Venezuela, with a discussion on the taxonomy of Mugil gaimardianus. Journal of Fish Biology 71, 76-97.

Hoeinghaus, D. J., Agostinho, A. A., Gomes, L. C., Pelicice, F. M., Okada, E. K., Latini, J. D., Kashiwaqui, E. A. L. \& Winemiller, K. O. (2009). Effects of river impoundment on ecosystem services of large tropical rivers: embodied energy and market value of artisanal fisheries. Conservation Biology 23, 1222-1231.

Hrbek, T., Farias, I. P., Crossa, M., Sampaio, I., Porto, J. I. R. \& Meyer, A. (2005). Population genetic analysis of Arapaima gigas, one of the largest freshwater fishes of the Amazon basin: implications for its conservation. Animal Conservation 8, 297-308. doi: $10.1017 / \mathrm{S} 1367943005002210$

Humphries, P. \& Winemiller, K. O. (2009). Historical impacts on river fauna, shifting baselines, and challenges for restoration. BioScience 59, 673-684.

Jaureguizar, A., Bava, J., Carozza, C. R. \& Lasta, C. (2003a). Distribution of the whitemouth croaker (Micropogonias furnieri) in relation to environmental factors at the Río de la Plata estuary, South America. Marine Ecology Progress Series 255, 271-282.

Jaureguizar, A., Menni, R., Bremec, C., Mianzan, H. \& Lasta, C. (2003b). Fish assemblage and environmental patterns in the Río de la Plata estuary. Estuarine Coastal and Shelf Science 56, 921-933. doi: 10.1016/S0272-7714 (02) 00288-3

Jaureguizar, A., Menni, R., Guerrero, R. \& Lasta, C. (2004). Environmental factors structuring fish communities of the Río de la Plata estuary. Fisheries Research 66, 195-211. doi: 10.1016/S0165-7836 (03) 00200-5

Jaureguizar, A. J., Ruarte, C. \& Guerrero, R. (2006a). Distribution of age-classes of striped weakfish (Cynoscion guatucupa) along an estuarine-marine gradient: correlations with the environmental parameters. Estuarine Coastal and Shelf Science 67, 82-92. doi: 10.1016/j.ecss.2005.10.014

Jaureguizar, A., Menni, R., Lasta, C. \& Guerrero, R. (2006b). Fish assemblages of the Northern Argentine coastal system: spatial patterns and their temporal variations. Fisheries Oceanography 15, 326-344. doi: 10.1111/j.1365-2419.2006.00405.x

Jaureguizar, A. J., Waessle, J. A. \& Guerrero, R. A. (2007). Estuarine dynamics controlling the Atlantic searobins (Prionotus spp) distribution on Southwestern Atlantic Coastal System $\left(34^{\circ}-41^{\circ}\right.$ S). Estuarine Coastal and Shelf Science 73, 30-42. doi: 10.1016/j. ecss.2006.12.012

Jaureguizar, A. J., Militelli, M. I. \& Guerreo, R. A. (2008). Environmental influence on maturity stage spatial distribution of whitemouth croaker (Micropogonias furnieri) along an estuarine gradient. Journal of the Marine Biological Association of the United Kingdom 88, 175-181. doi: 10.1017/S0025315408000167

Jiménez-Segura, L. F. (2007). Ictioplancton y periodos reproductivos de los peces en la cuenca media del Río Magdalena. DSc Thesis, Universidad de Antioquia, Medellin, Colombia.

Johnston, I. A., Sidell, B. D. \& Driedzic, W. R. (1985). Force-velocity characteristics and metabolism of carp muscle fibres following temperature acclimation. Journal of Experimental Biology 119, 239-249.

Junk, W. J. \& Wantzen, K. M. (2004). The flood pulse concept: new aspects, approaches and applications - an update. In Proceedings of the Second International Symposium on the Management of Large Rivers for Fisheries (LARS 2) (Welcomme, R. \& Petr, T., eds), pp. 117-149. Bangkok: Food and Agriculture Organization and Mekong River Commission, FAO Regional Office for Asia and the Pacific. 
Junk, W. J., Soares, G. M. \& Carvalho, F. M. (1983). Distribution of fish species in a lake of the Amazon river floodplain near Manaus (lago Camaleão), with special reference to extreme oxygen conditions. Amazoniana 7, 397-431.

Junk, W. J., Bayley, P. B. \& Sparks, R. E. (1989). The flood pulse concept in river - floodplain systems. Special Publication of the Canadian Journal of Fisheries and Aquatic Sciences 106, 10-127.

Kawasaki, T. (1980). Fundamental relations among the selections of life history in the marine teleosts. Bulletin of the Japanese Society of Scientific Fisheries 46, 289-293.

Kennish, M. J. (1992). Ecology of Estuaries: Anthropogenic Effects. Boca Raton, FL: CRC Press.

Kennish, M. J. (1998). Pollution Impacts on Marine Biotic Communities. Boca Raton, FL: CRC Press.

Kobayashi, J. T., Thomaz, S. M. \& Pelicice, F. M. (2008). Phosphorus as a limiting factor for Eichhornia crassipes growth in the upper Paraná River floodplain. Wetlands 28, 905-913.

Krumme, U., Saint-Paul, U. \& Rosenthal, H. (2004). Tidal and diel changes in the structure of a nekton assemblage in small intertidal creeks in northern Brazil. Aquatic Living Resources 17, 215-229. doi: 10.1051/alr: 2004019

Krumme, U., Keuthen, H., Barletta, M. \& Saint-Paul, U. (2005). Contribution to the feeding ecology of the predatory wingfin anchovy Pterengraulis atherinoides (L.) in nothern Brazilian mangrove creeks. Journal of Applied Ichthyology 21, 469-477.

Kullander, S. O. (2003). Family Cichlidae (Cichlids). In Check List of the Freshwater Fishes of South and Central America (Reis, R. E., Kullander, S. O. \& Ferraris, C. J. Jr., eds), pp. 605-654. Porto Alegre: Edipucrs.

Lacerda, L. D., Conde, J. E., Kjerfve, B., Alravez-Lean, R., Alarcón, C. \& Polania, J. (2002). American mangroves. In Mangrove Ecosystems: Function and Management (Lacerda, L. D., ed.), pp. 1-62. Berlin: Springer.

Laegdsgaard, P. \& Johnson, C. R. (1995). Fish communities in subtropical mangroves and adjacent habitats: the importance of nurseries for commercial species. Marine Ecology Progress Series 126, 67-81.

Langeani, F., Castro, R. M. C., Oyakawa, O. T., Shibatta, O. A., Pavanelli, C. S. \& Casatti, L. (2007). Diversidade da ictiofauna do alto Rio Paraná: composição atual e perspectivas futuras. Biota Neotropica 7, 181-197.

Lasso, C. A. (1989). Los peces de la Gran Sabana, alto Caroní, Venezuela. Memoria Sociedad Ciencias Naturales La Salle 49-50, 209-285.

Lasso, C. (2001). Ecología y conservación del pavón. Caracas: Fundación Cisneros.

Lasso, C. A. (2008). Peces. In Libro Rojo de la fauna Venezolana. Tercera Edición (Rodríguez, J. P. \& Rojas, J., eds), pp. 220-264. Caracas: Provita y Shell Venezuela S.A.

Lasso, C., Mojica, J., Usma, J., Maldonado-Ocampo, J., DoNascimiento, C., Taphorn, D., Provenzano, F., Lasso-Alcalá, O., Gálvis, G., Vásquez, L., Lugo, M., Machado-Allison, A., Royero, R., Suárez, C. \& Ortega-Lara, A. (2004). Peces de la cuenca del río Orinoco. Parte I: Lista de especies y distribución por cuencas. Biota Colombiana 5, $95-158$.

Lasso, C., Señaris, J., Alonso, L. \& Flores, A. (Eds) (2006a). Evaluación Rápida de la Biodiversidad de los Ecosistemas Acuáticos de la Confluencia de los Ríos Orinoco y Ventuari, Estado Amazonas, Venezuela. Boletin RAP de Evaluación Brologica 30.

Lasso, C., Giraldo, A., Lasso-Alcalá, O., León-Mata, O., DoNascimiento, C., Milani, N., Rodríguez-Olarte, D., Señaris, J. \& Taphorn, D. (2006b). Peces de los ecosistemas acuáticos de la confluencia de los ríos Orinoco y Ventuari, Estado Amazonas, Venezuela: resultados del AquaRAP 2003. In Evaluación Rápida de la Biodiversidad de los Ecosistemas Acuáticos de la Confluencia de los Ríos Orinoco y Ventuari, Estado Amazonas, Venezuela (Lasso, C., Señaris, J., Alonso, L. \& Flores, A., eds), pp. 114-122. Boletin RAP de Evaluación Brologica 30.

Lasso, C. A., Lasso-Alcalá, O. \& Rojas, H. (2009). Peces del Parque Nacional Canaima. In Biodiversidad del Parque Nacional Canaima: Bases Técnicas para la Conservación de la Guayana Venezolana (Señaris, J., Lew, D. \& Lasso, C. A., eds), pp. 79-101. Caracas: Fundación La Salle de Ciencias Naturales-The Nature Conservancy Venzuela. 
Lasta, C. A. (1995). La Bahía Samborombon: zona de desove y cría de peces. PhD Thesis, Universidad Nacional de La Plata, Argentina.

Lasta, C. A., Bremec, C. \& Mianzan, H. (1998). Áreas ícticas costeras en la Zona Común de Pesca Argentino-Uruguaya (ZCPAU) y en el litoral de la provincia de Buenos Aires. INIDEP Informe Técnico 21, 91-101.

LeGrande, W. H. \& Fitzsimons, J. M. (1976). Karyology of the mullets Mugil curema and M. cephalus (Perciformes: Mugilidae) from Louisiana. Copeia 1976, 388-391.

Lévequè, C., Oberdorff, T., Paugy, D., Stassny, M. L. J. \& Tedesco, P. A. (2008). Global diversity os fish (Pisces) in freshwater. Hydrobiologia 595, 545-587.

Lilyestrom, C. G. \& Taphorn, D. C. (1983). Apuntes sobre la biología y conservación de la Palambra (Brycon whitei). Revista UNELLEZ de Ciencia y Tecnología 1, 53-60.

López, H. L. \& Miquelarena, A. M. (2005). Biogeografía de los peces continentales de la Argentina. In Regionalización biogeográfica en Latinoamérica y tópicos afines (Llorente Bousquets, J. \& Morrone, J. J., eds), pp. 509-550. México City: CYTED.

Lorenzo Pereiro, M. I. (2007). Estructura de la comunidad de peces demersales en el Río de la Plata y su frente oceánico. PhD Thesis, Universidad Nacional de Mar del Plata, Argentina.

Lowe-McConnell, R. H. (1987). Ecological Studies in Tropical Fish Communities. Cambridge: Cambridge University Press.

Lucas, A. J., Guerrero, R. A., Mianzan, H., Acha, E. M. \& Lasta, C. A. (2005). Coastal oceanographic regimes of the Northern Argentine Continental Shelf (34-43 S). Estuarine Coastal and Shelf Science 65, 405-420. doi: 10.1016/j.ecss.2005.06.015

Ludwig, J. A. \& Reynolds, J. F. (1998). Statistical Ecology: A Primes on Methods and Computing. New York, NY: John Wiley \& Sons Inc.

Luz-Agostinho, K. D. G., Agostinho, A. A., Gomes, L. C., Júlio-Jr, H. F. \& Fugi, R. (2009). Effects of flooding regime on the feeding activity and body condition of piscivorous fish in the upper Paraná River floodplain. Brazilian Journal of Biology 69 (Suppl. 2), $481-490$.

Machado, V. (2009). Análise da variabilidade genética da curimatã, Prochilodus nigricans (Agassis, 1829) na calha do rio Amazonas e seus principais tributários. MSc Thesis. CIPET, Universidade Federal do Amazonas, Manaus, Brazil.

Machado-Allison, A. (1994). Factores que afectan las comunidades de peces en las áreas inundables de Venezuela. Acta Biológica Venezuelica 15, 59-75.

Machado-Allison, A. (2007). Sobre el origen del río Orinoco, su relación con cuencas vecinas, las evidencias biológico-paleontológicas y la conservación de hábitats acuáticos: una revisión basada en la información íctica. Boletín Academia de Ciencias Físicas, Matemáticas y Naturales 57, 25-64.

Mago, F. (1970). Lista de los peces de Venezuela. Caracas: Ministerio de Agricultura y Cría - Oficina Nacional de Pesca.

Malabarba, L. R. (1989). Histórico sistemático e lista comentada das espécies de peixes de água doce do sistema da Laguna dos Patos, Rio Grande do Sul, Brasil. Comunicação do Museu de Ciências da PUCRS (Ser. Zool.) 2, 107-179.

Maldonado-Ocampo, J., Vari, R. \& Usma, J. S. (2008). Checklist of the freshwater fishes in Colombia. Biota Colombiana 9, 143-237.

Marques, M., Costa, M. F., Mayorga, M. I. O. \& Pinheiro, P. (2004). The water environment: anthropogenic pressures and ecosystem changes in the Atlantic drainage basins of Brazil. AMBIO 33, 68-77.

Matsuo, A. Y. O., Duarte, R. M. \& Val, A. L. (2005). Unidirectional sodium fluxes and gill CYP1A induction in an Amazonian fish (Hyphessobrycon erythrostigma) exposed to a surfactant and to crude oil. Bulletin of Environmental Contamination Toxicology 75, $851-858$

Melville-Smith, R., Baird, D. \& Woolridge, T. (1981). The utilization of tidal currents by larvae of estuarine fish. South African Journal of Zoology 16, 10-13.

Menni, R. C. (2004). Peces y ambientes en la Argentina continental. Monografías del Museo Argentino de Ciencias Naturales 5, 1-316.

Menni, R. C. \& Gosztonyi, A. E. (1982). Benthic and semidemersal fish associations in the Argentine Sea. Studies on Neotropical Fauna and Environment 17, 1-29. 
Merona, B. (1987). Aspectos ecológicos da ictiofauna no Baixo Tocantins. Acta Amazônica 17, 109-124.

Milani, P. C. C. \& Fontoura, N. F. (2007). Diagnóstico da pesca artesanal na Lagoa do Casamento, sistema nordeste da Laguna dos Patos: uma proposta de manejo. Biociências 15, 82-125.

Mojica, J. I., Galvis, G., Sanchez-Duarte, P., Castellanos, C. \& Villa-Navarro, F. A. (2006). Peces del valle medio del río Magdalena, Colombia. Biota Colombiana 7, 23-38.

Möller, O. O., Casting, J. P., Salomon, J. C. \& Lazure, P. (2001). The influence of local and non-local forcing effects on the subtidal circulation of Patos Lagoon. Estuaries 24, 297-311.

Montaña, C., Taphorn, D., Layman, C. \& Lasso, C. (2007). Distribución, alimentación y reproducción de tres especies de pavones, Cichla spp. (Perciformes, Cichlidae) en la cuenca baja del río Ventuari, Estado Amazonas, Venezuela. Memoria de la Fundación La Salle de Ciencias Naturales 165, 83-102.

Morais, T. A. \& Morais, T. L. (1994). The abundance and diversity of larval and juvenile fish in a tropical estuary. Estuaries 17, 216-225.

Morton, R. M. (1990). Community structure, density and standing crop of fishes in a subtropical Australian mangrove area. Marine Biology 105, 385-394.

Moyle, P. B. \& Cech, J. J. Jr. (1996). Fishes: An Introduction to Ichthyology. Upper Saddle River, NJ: Prentice Hall.

Nirchio, M. \& Cequea, H. (1998). Karyology of Mugil liza and Mugil curema from Venezuela. Boletín de Investigaciones Marinas y Costeras 27, 45-50.

Nirchio, M., Cervigón, F., Rebelo Porto, J. I., Pérez, J. E., Gómez, J. A. \& Villalaz, J. (2003). Karyotype supporting Mugil curema Valenciennes, 1836 and Mugil gaimardianus Desmarest, 1831 (Mugilidae: Teleostei) as two valid nominal species. Scientia Marina 67, $113-115$.

Nirchio, M., Cipriano, R., Cestari, M. \& Fenocchio, A. S. (2005). Cytogenetical and morphological features reveal significant differences among Venezuelan and Brazilian samples of Mugil curema (Teleostei: Mugilidae). Neotropical Ichthyology 3, 107-110.

Nolan, K. S., Fabré, N. N. \& Batista, V. S. (2009). Landscape variables affecting fishery yield in lake systems of the Central Amazon region, Brazil. Journal of Applied Ichthyology 25, 294-298. doi: 10.1111/j.1439-0426.2008.01122.x

Novoa, D. (2002). Los recursos pesqueros del eje fluvial Orinoco-Apure: presente y futuro. Caracas: Ministerio de Agricultura y Tierras. INAPESCA.

Odebrecht, C., Abreu, P. C., Möller, O. O., Niencheski, L. F., Proença, L. A. \& Torgan, L. C. (2005). Drought effects on pelagic properties in the shallow and turbid Patos Lagoon, Brazil. Estuaries 28, 675-686.

Odebrecht, C., Abreu, P. C., Bemvenuti, C. E., Copertino, M., Muelbert, J. H., Vieira, J. P. \& Seeliger, U. (2010). The Patos Lagoon Estuary: biotic responses to natural and anthropogenic impacts in the last decades (1979-2008). In Coastal Lagoons: Critical Habitats of Environmental Change (Kennish, M. J. \& Paerl, H. W., eds), pp. 437-459. Boca Raton, FL: Taylor \& Francis CRC Press.

Ogden, R., Dawnay, N. \& McEwing, R. (2009). Wildlife DNA forensics - bridging the gap between conservation genetics and law enforcement. Endangered Species Research 9, 179-195. doi: 10.3354/esr00144

Okada, E. K., Agostinho, A. A. \& Gomes, L. C. (2005). Spatial and temporal gradients in artisanal fisheries: a case study of the Itaipu Reservoir, Brazil. Canadian Journal of Fisheries and Aquatic Sciences 62, 714-724.

Oldani, N. O. (1990). Variaciones de la abundancia de peces del valle del Río Paraná, Argentina. Revue Hidrobiologie Tropicale 23, 67-76.

Oldani, N. \& Baigún, C. (2002). Performance of a fishway system in a major South American dam on the Paraná River (Argentina-Paraguay). River Research and Applications 18, $171-183$.

Oliveira, M. I. (1997). Determinação da idade e aspectos da dinâmica populacional do Curimatá Prochilodus nigrans (Pisces; Prochilodontidae) da Amazônia Central. MSc Thesis, Universidade Federal do Amazonas, Manaus, Brazil. 
Palma, E. D., Matano, R. P. \& Piola, A. R. (2004). A numerical study of the Southwestern Atlanctic Shelf circulation: barotropic response to tidal and wing forcing. Journal of Geophysical Research 109, 1-17. doi: 10.1029/2004JC002315

Paully, M. \& Rodriguez, M. (2004). Determinism of fish assemblage structure in noetropical floodplain lakes: influence of internal and landscape conditions. In Proceedings of the Second International Symposium on the Management of Large Rivers for Fisheries (LARS 2) (Welcomme, R. \& Petr, T., eds), pp. 243-265. Bangkok: Food and Agriculture Organization and Mekong River Commission, FAO Regional Office for Asia and the Pacific.

Pereira, A. S., Milani, P. C. C. \& Fialho, C. B. (2006). Primeiro registro de Acestrorhynchus pantaneiro Menezes, 1992 (Characiformes, Acestrorhynchidae) no sistema da laguna dos Patos, Rio Grande do Sul, Brasil. Biota Neotropica 6, 1-4.

Pereira, L. H. G., Foresti, F. \& Oliveira, C. (2009). Genetic structure of the migratory catfish Pseudoplatystoma corruscans (Siluriformes: Pmelodidae) suggests homing behaviour. Ecology of Freshwater Fish 18, 215-225.

Perez, A. \& Fabré, N. N. (2003). Seleção das estruturas calcificadas para a determinação da idade da Piracatinga Calophysus macropterus Lichtenstein, 1819 (Pisces: Pimelodidade) na Amazônia Central, Brasil. Acta Amazônica 34, 120-124.

Petrere, M. Jr. (1983). Relationships among catches, fishing effort and river morphology for eight rivers in Amazonas States (Brazil), during 1976-1978. Amazoniana 8, 281-296.

Petrere, M. Jr. (1996). Fisheries in large tropical reservoir in South America. Lakes and Reservoirs: Research and Management 2, 111-133.

Petrere, M. Jr., Agostinho, A. A., Okada, E. K. \& Júlio, H. F. Jr. (2002). Review of the fisheries in the Brazilian portion of the Paraná/Pantanal basin. In Management and Ecology of Lake and Reservoir Fisheries (Cowx, I., ed.), pp. 123-143. London: Fishing News Books.

Petry, P. B., Bayley, P. B. \& Markle, D. F. (2003). Relationships between fish assemblages, macrophytes and environmental gradients in the Amazon River floodplain. Journal of Fish Biology 63, 547-579. doi: 10.1046/j.1095-8649.2003.00169.x

Pignalberi de Hassan, C. \& Cordiviola de Yuan, E. (1985). Fish populations in the Parana River. I. Temporary water bodies of Santa Fe and Corrientes areas, 1970-1971 (Argentine Republic). Studies on Neotropical Fauna and Environment 20, 15-26.

Prenski, B. \& Sánchez, F. (1988). Estudio preliminar sobre asociaciones ícticas en la Zona Común de Pesca Argentino-Uruguaya. Publicaciones de la Comisión Técnica Mixta del Frente Marítimo 4, 75-87.

Quirós, R. (1990). The Paraná River Basin development and the changes in the lower basin fisheries. Interciencia 15, 442-451.

Quirós, R. (2004). The La Plata river basin: international basin development and riverine fisheries. In Proceedings of the Second International Symposium on the Management of Large Rivers for Fisheries (Welcomme, R. L. \& Petr, T., eds), pp. 253-272. Bangkok, Thailand: Food and Agriculture Organization and Mekong River Commission, FAO Regional Office for Asia and the Pacific.

Quirós, R. \& Cuch, S. (1989). The fisheries and limnology of the lower Plata basin. In Proceedings of the International Large River Symposium (Dodge, D. P., ed.), pp. 429-443. Canadian Special Publication of Fisheries and Aquatic Sciences 106.

Reis, E. G., Vieira, P. C. \& Duarte, V. S. (1994). Pesca artesanal de teleósteos no estuário da Lagoa dos Patos e costa do Rio Grande do Sul. Atlântica 16, 55-68.

Reis, R. E., Lucena, Z. M. S., Lucena, C. A. S. \& Malabarba, L. R. (2003a). Peixes. In Livro vermelho da fauna ameaçada de extinção no Rio Grande do Sul (Fontana, C. S., Bencke, G. A. \& Reis, R. E., eds), pp. 117-145. Porto Alegre: Edipucrs.

Reis, R. R., Kullander, S. O. \& Ferraris, C. J. (2003b). Check List of the Freshwater Fishes of South and Central America. Porto Alegre: Edipucrs.

Ribeiro, M. C. L. B. \& Petrere, M. Jr. (1990). Fisheries ecology and management of the Jaraqui (Semaprochilodus taeniurus, S. insignis) in Central Amazonia. Regulated Rivers: Research and Management 5, 195-215.

Robert, M. C. \& Chaves, P. T. (2001). Observações sobre o ciclo de vida da corvina, Micropogonias furnieri (Desmarest) (Teleostei, Scianidae), no litoral do Estado do Paraná, Brasil. Revista Brasileira de Zoologia 18, 421-428. 
Roberto, M. C., Santana, N. F. \& Thomaz, S. M. (2009). Limnology in the Upper Paraná River foodplain: large-scale spatial and temporal patterns, and the influence of reservoirs. Brazilian Journal of Biology 69 (Suppl. 2), 717-725.

Robertson, A. W. \& Mechoso, C. R. (1998). Interannual and decadal cycles in river flows of Southeastern South America. Journal of Climate 11, 2570-2581. doi: 10.1175/15200442 (1998)011

Rocha, L. A., Robertson, D. R., Roman, J. \& Bowen, B. W. (2005). Ecological speciation in tropical reef fishes. Proceedings of the Royal Society B 272, 573-579.

Rodrigues, L. H. R. (2009). Reguladores da dinâmica das comunidades planctônicas e íctica em sistemas límnicos subtropicais. PhD Thesis. Universidade Federal do Rio Grande do Sul, Porto Alegre, Brazil.

Rodrigues, R., Schneider, H., Santos, S., Vallinoto, M., Saint-Paul, U. \& Sampaio, I. (2008). Low levels of genetic diversity depicted from mitochondrial DNA sequences in a heavily exploited marine fish (Cynoscion acoupa, Sciaenidae) from the Northern coast of Brazil. Genetics and Molecular Biology 31, 487-492.

Rodríguez, O. D. \& Taphorn, D. (2006). Abundance, feeding and reproduction of Salminus sp. (Pisces: Characidae) from mountain streams of the Andean piedmont in Venezuela. Neotropical Ichthyology 4, 73-79.

Rodríguez, O. D., Coronel, O. J., Amaro, A. \& Taphorn, D. (2007). Línea base para la estimación de la integridad en comunidades de peces en la cuenca del río Tocuyo, vertiente del Caribe, Venezuela. Memoria de la Fundación La Salle de Ciencias Naturales 165, 63-81.

Santos, G. M., Ferreira, E. J. G. \& Zuanon, J. A. S. (1991). Ecologia de peixes da Amazônia. In Bases Científicas para estratégias de preservação e desenvolvimento da Amazônia: Fatos e Perspectivas (Val, A. L., Figliuolo, R. \& Feldberg, E., eds), pp. 263-280. Manaus: INPA.

Santos, M. D. C. F., Ruffino, M. L. \& Farias, I. P. (2007). High levels of genetic variability and panmixia of the tambaqui Colossoma macropomum (Cuvier, 1818) in the main channel of the Amazon River. Journal of Fish Biology 71, 33-44. doi: 10.1111/j.10958649.2007.01514.x

Santos, S., Schneider, H. \& Sampaio, I. (2003). Genetic differentiation of Macrodon ancylodon (Sciaenidae, Perciformes) populations in Atlantic coastal waters of South America as revealed by mtDNA analysis. Genetics and Molecular Biology 26, 151-161.

Santos, S., Hrbek, T., Farias, I. P., Schneider, H. \& Sampaio, I. (2006). Population genetic structuring of king weakfish, Macrodon ancylodon (Sciaenidae), in Atlantic coastal eaters of South America: deep genetic divergence without morphological change. Molecular Ecology 15, 4361-4373.

Santos-Filho, L. C. \& Batista, V. S. (2005). Determinação de idade e crescimento do mapará (Hypophthalmus marginatus) na Amazônia Central. Acta Amazônica 35, 85-92.

Sarpedonti, V., Anunciação, E. M. S. \& Isaac, V. J. N. (2008). Ichthyoplankton variations in two mangrove creeks of the Curuçá estuary, Pará, Brazil. Ecotrópicos 21, 1-12.

Simionato, C. G., Dragan, W., Meccia, V. \& Núñez, M. (2004). A numerical study of the barotropic circulation of the Río de la Plata estuary: sensitivity to bathymetry, the Earths rotation and low frequency wind variability. Estuarine, Coastal and Shelf Science 61, 261-273. doi: 10.1016/j.ecss.2004.05.005

Sioli, H. 1984. The Amazon. Limnology and Landscape Ecology of a Mighty Tropical River and its Basin. Dordrecht: Dr W. Junk Publishers.

SNUC (2000). Sistema Nacional de Unidades de Conservação. Lei Federal n ${ }^{\circ} 9985$ de 18 de julho de 2000. (Brazilian Environmental Law).

Soares, M. G. M., Almeida, R. G. \& Junk, W. J. (1986). The trophic status of the fish fauna in Lago Camaleão, a macrophyte dominated floodplain lake in the middle Amazon. Amazoniana 9, 511-526.

Souza, L. M. \& Chaves, P. T. (2007). Atividade reprodutiva de peixes (Teleostei) e o defeso da pesca de arrasto no litoral norte de Santa Catarina, Brasil. Revista Brasileira de Zoologia 24, 1113-1121.

Souza Filho, E. E., Rocha, P. C., Comunello, E. \& Stevaux, J. C. (2004). Effects of the Porto Primavera Dam on physical environment of the downstream floodplain. In The Upper 
Parana River Floodplain Physical Aspects, Ecology and Conservation (Thomaz, S. M., Agostinho, A. A. \& Hahn, N. S., eds), pp. 55-74. Leiden: Backhuys Publishers.

Souza Filho, P. W. M. (2005). Costa de manguezais de macromaré da Amazônia: cenários morfológicos, mapeamento e quantificação a partir de dados de sensores remotos. Revista Brasileira de Geofísica 23, 427-435.

Suzuki, H. I., Agostinho, A. A., Bailly, D., Gimenes, M. F., Júlio-Junior, H. F. \& Gomes, L. C. (2009). Inter-annual variations in the abundance of young-of-the-year of migratory fishes in the Upper Paraná River floodplain: relations with hydrographic attributes. Brazilian Journal of Biology 69 (Suppl. 2), 649-660.

Sverlij, S. B. \& Espinach Ros, A. (1986). El dorado, Salminus maxillosus (Pisces, Characiformes), en el Río de la Plata y río Uruguay Inferior. Revista de Investigación y Desarrollo Pesquero (Mar del Plata) 6, 57-75.

Sverlij, S. B., Espinach Ros, A. \& Orti, G. (1993). Sinopsis de los datos biológicos y pesqueros del sábalo Prochilodus lineatus (Valenciennes, 1847). FAO Sinopsis sobre la Pesca 154.

Taphorn, D. \& García, J. (1991). El río Claro y sus peces, con consideraciones de los impactos ambientales de las presas sobre la ictiofauna del Bajo Caroní. Biollania 8, 23-45.

Thomaz, S. M., Bini, L. M. \& Bozelli, R. L. (2007). Floods increase similarity among aquatic habitats in river-floodplain systems. Hydrobiologia 579, 1-13.

Thomaz, S. M., Carvalho, P., Padial, A. A. \& Kobayashi, J. T. (2009). Temporal and spatial patterns of aquatic macrophyte diversity in the Upper Paraná River foodplain. Brazilian Journal of Biology 69 (Suppl. 2), 617-625.

Thomé-Souza, M. J. F. \& Chao, N. L. (2004). Spatial and temporal variation of benthic fish assemblages during the extreme drought of 1997-98 (El Niño) in the middle rio Negro, Amazonia, Brazil. Neotropical Ichthyology 2, 127-136.

Torres, R. A. (2003). New frontiers in conservation biology: the era of the genome. Brazilian Journal of Nature Conservation 1, 60-62.

Torres, R. A., Motta, T. S., Nardinho, D., Adam, M. L. \& Ribeiro, J. (2008). Chromosomes, RAPDs and evolutionary trends of Neotropical fish Mimagoniates microleps (Teleostei: Characidae: Glandulocaudine) from coastal and continental regions of the Atlantic forest, Southern Brazil. Acta Zoologica 89, 253-259.

Tucci, C. E. M. \& Clarke, R. T. (1998). Environmental issues in the La Plata Basin. Water Resources Development 14, 157-174.

Val, A. L. (1996). Surviving low oxygen levels: lessons from fishes of the Amazon. In The Physiology of Tropical Fishes, Vol. 21 (Val, A. L., Almeida-Val, V. M. F. \& Randall, D. J., eds), pp. 59-73. London: Elsevier.

Val, A. (1997). Efeitos do petróleo sobre a respiração de peixes da Amazônia. In Indicadores Ambientais (Martos, H. L. \& Maia, N. B., eds), pp. 109-119. Sorocaba, SP: Pontifícia Universidade Católica.

Val, A. L. \& Almeida-Val, V. M. F. (1995). Fishes of the Amazon and Their Environments. Physiological and Biochemical Features. Heidelberg: Springer Verlag.

Val, A. L. \& Almeida-Val, V. M. F. (1999). Effects of crude oil on respiratory aspects of some fish species of the Amazon. In Biology of Tropical Fish (Val, A. L. \& AlmeidaVal, V. M. F., eds), pp. 277-291. Manaus: INPA.

Val, A. L., Silva, M. N. P. \& Almeida-Val, V. M. F. (1998). Hypoxia adaptation in fish of the Amazon: a never-ending task. South African Journal of Zoology 33, 107-114.

Val, A. L., Almeida-Val, V. M. F. \& Randall, D. J. (2006). Tropical environment. In The Physiology of Tropical Fishes, Vol. 21 (Val, A. L., Almeida-Val, V. M. F. \& Randall, D. J., eds), pp. 1-45. London: Elsevier.

Valentine, A., Ponpanon, F. \& Taberlet, P. (2008). DNA barcoding for ecologists. Trends in Ecology \& Evolution 24, 110-117.

Viana, A. P., Lucena Frédou, F., Frédou, T., Torres, M. F. \& Bordalo, A. O. (2010). Fish fauna as an indicator of environmental quality in an urbanized region of the Amazon estuary. Journal of Fish Biology 76, 467-486.

Vicari, M. R., Pazza, R., Artoni, R. F., Margarido, W. P. \& Bertollo, L. A. C. (2006). Cytogenetics and biogeography: considerations about the natural origin of Hoplias malabaricus (Characiformes, Erythrinidae) on the Iguaçu River. Brazilian Archives of Biology and Technology 49, 297-303. 
Vieira, J. P. \& Castello, J. P. (1997). Fish fauna. In Subtropical Convergence Environments The Coast and Sea in the Southwestern Atlantic (Seeliger, U., Odebrecht, C. \& Castello, J. P., eds), pp. 56-61. New York, NY: Springer.

Vieira, J. P., Garcia, A. M., Grimm, A. M. (2008). Preliminary evidences of El Niño effects on the mullet fishery of Patos Lagoon estuary (Brazil). Brazilian Archives of Biology and Technology 52: 433-440.

Villacorta-Correa, M. A. (1987). Crescimento do matrinxã, Brycon cephalus (Günther,1869) (Teleostei, Characidae) no baixo Rio Negro, seus afluentes e no baixo Rio Solimões. MSc Thesis, Instituto Nacionalde Pesquisa da Amazônia, Universidade Federal do Amazonas, Manaus, Brazil.

Way-Kleckner, N. \& Sidell, B. D. (1985). Comparison of maximal activities of enzymes from tissues of thermally acclimated and naturally acclimatized chain pickerel (Esox niger). Physiological Zoology 58, 18-28.

Weschenfelder, J., Corrêa, I. C. S., Toldo, E. E. \& Baitelli, R. (2008). Paleocanais como indicativo de eventos regressivos quaternários do nível do mar no sul do Brasil. Revista Brasileira de Geofísica 26, 367-375.

West, J. L., Bailey, J. R., Almeida-Val, V. M. F., Val, A. L., Sidell, B. D. \& Driedzic, W. R. (1999). Activity levels of enzymes of energy metabolism in heart and red muscle are higher in north-temperate-zone than in Amazonian teleosts. Canadian Journal of Zoology 77, 690-696.

Whitfield, A. K. (1994a). An estuary-association classification for the fishes of southern Africa. South African Journal of Science 90, 411-417.

Whitfield, A. K. (1994b) Fish species diversity in southern African estuarine systems: an evolutionary perspective. Environmental Biology of Fishes 40, 37-48.

Winemiller, K. O. (1989). Patterns of variation in life history among South American fishes in seasonal environments. Oecologia 8, 225-241.

Winemiller, K. O. \& Jepsen, D. B. (1998). Effects of seasonality and fish movement on tropical river food webs. Journal of Fish Biology 53 (Suppl. A), 267-296.

Winemiller, K. O. \& Rose, K. A. (1992). Patterns of life-history diversification in North American fishes: implications for population regulation. Canadian Journal Fisheries and Aquatic Sciences 49, 2196-2218.

Winemiller, K. O., Marrero, C. \& Taphorn, D. (1996). Perturbaciones causadas por el hombre a las poblaciones de peces de los llanos y del piedemonte andino de Venezuela. BioLlania 12, 13-48.

Wootton, R. J. (1998). Ecology of Teleost Fishes, 2nd edn. Amsterdam: Kluwer Academic Publishers.

$\mathrm{Wu}, \mathrm{R}$. (2002). Hypoxia: from molecular responses to ecosystem responses. Marine Pollution Bulletin 45, 35-45.

Zaniboni-Filho, E. (1985). Biologia da reprodução do matrinchã, Brycon cephalus (Gunther, 1869) (Teleostei, Characidae). MSc Thesis, Instituto Nacional de Pesquisa da Amazônia, Universidade Federal do Amazonas, Manaus, Brazil.

Zimmer, K. D., Hanson, M. A. \& Butler, M. G. (2003). Interspecies relationships, community structure, and factors influencing abundance of submerged macrophytes in prairie wetlands. Wetlands 23, 717-728.

\section{Electronic References}

Baigún, C., Sverlij, S. \& López, H. L. (2003). Informe final sobre pesquerías continentales argentinas del Río de la Plata. PNUD/GEF/RLA799/G31. Available at www.freplata. org/documentos; www.fceqyn.unam.edu.r/icades

CORMAGDALENA (2007). Formulación del plan de manejo de la cuenca del Río Magdalena - Segunda Fase. Barrancabermeja: CORMAGDALENA. Available at www. Cormagdalena.com.co

CCI (2007). Informe anual de Pesca y acuicultura en Colombia 2007. Bogotá: Ministerio de Agricultura y Desarrollo Rural. Available at www.cci.org.co

Cortés, F., Jaureguizar, A. J., Menni, R. C. \& Guerrero, R. A. (2008). Habitat preferences of Mustelus schmitti in two Southwestern atlantic coastal systems. Conference Abstract 
VI Reunión de la Sociedad Brasilera para o Estudo de Elasmobranquios (SBEEL). Fortaleza: SBEEL. Available at www.sbeel.org.br

DANE (2004). Departamento Administrativo Nacional - Información Estadística. Available at http://www.dane.gov.co/inf_est/inf_est.htm

Espinach Ros, A. \& Fuentes, C. (2000). Recursos pesqueros y pesquerías de la Cuenca del Plata. Publicaciones especiales Instituto de Investigación y Desarrollo Pesquero, Mar del Plata, pp. 353-388. Available at www.inidepaedu.ar

García, M., Protogino, L. \& Jaureguizar, A. J. (2003). III Informe científico "Asociaciones ícticas y aspectos biológicos de las especies más abundantes colectadas durante la campaña de prospección pesquera en el Río de la Plata" dentro del marco del Proyecto "Protección ambiental del Río de la Plata y su frente marítimo: prevención y control de la contaminación y restauración de hábitats”, Diciembre de 2003. PNUD/GEF/RLA/99/ G31. Available at www.inidep.edu.ar.org/gef/05/documents/writeups_doc/iw/Rio_ delaplata.doc

Lagos, A. N. (2001). Características de la pesca artesanal en el Partido de la Costa (Cabo San Antonio) y perfil socioeconómico de la actividad. MS Thesis, Universidad Nacional de Mar del Plata, Mar del Plata, Argentina. Available at http://hdl.handle.net/1834/1490

López, H. L., Morgan, C. C. \& Montenegro, M. J. (2002). Ichthyological Ecoregions of Argentina. Pro Biota, Serie Documentos $N^{\circ}$ 1. Available at www.vidasilvestre.org.ar

Nagy, G. J., Bidegain, M., Caffera, R. M., Lagomarsino, J. J., Norbis, W., Ponce, A. \& Sención, G. (2006). Adaptive capacity for responding to climate variability and change in estuarine fisheries of the Río de la Plata. AIACC Working Series Paper No. 36. Washington, DC: International START Secretariat. Available at http://www.aiaccproject.org

UNEP (2004a). Amazon Basin, GIWA Regional Assessment 40b. Kalmar: University of Kalmar. Available at http://www.unep.org/dewa/giwa/

UNEP (2004b). Brazil Current, GIWA Regional Assessment 39. Kalmar: University of Kalmar. Available at http://www.unep.org/dewa/giwa/

UNEP (2004c). Patagonian Shelf, GIWA Regional Assessment 38. Kalmar: University of Kalmar. Available at http://www.unep.org/dewa/giwa/

UNEP (2006a). Caribbean Sea/Colombia \& Venezuela, Caribbean Sea/Central America \& Mexico, GIWA Regional Assessment 3b, 3c. Kalmar: University of Kalmar. Available at http://www.unep.org/dewa/giwa/

UNEP (2006b). Permanent Commission for the South Pacific (CPPS). Eastern Equatorial Pacific, GIWA Regional Assessment 65. Kalmar: University of Kalmar. Available at http://www.unep.org/dewa/giwa/

UNEP (2006c). Permanent Commission for the South Pacific (CPPS). Humboldt Current, GIWA Regional Assessment 64. Kalmar: University of Kalmar. Available at http://www. unep.org/dewa/giwa/ 